\title{
Re-analysis of tropospheric sulfate aerosol and ozone for the period 1980-2005 using the aerosol-chemistry-climate model ECHAM5-HAMMOZ
}

\author{
L. Pozzoli ${ }^{1}{ }^{*}$, G. Janssens-Maenhout ${ }^{1}$, T. Diehl' ${ }^{2,3}$, I. Bey ${ }^{4}$, M. G. Schultz ${ }^{5}$, J. Feichter ${ }^{6}$, E. Vignati ${ }^{1}$, and F. Dentener ${ }^{1}$ \\ ${ }^{1}$ European Commission, Joint Research Centre, Institute for Environment and Sustainability, Ispra, Italy \\ ${ }^{2}$ NASA Goddard Space Flight Center, Greenbelt, Maryland, USA \\ ${ }^{3}$ University of Maryland Baltimore County, Baltimore, Maryland, USA \\ ${ }^{4}$ Center for Climate Systems Modeling and Institute of Atmospheric and Climate Science, ETH Zurich, Zurich, Switzerland \\ ${ }^{5}$ Forschungszentrum Jülich, Germany \\ ${ }^{6}$ Max Planck Institute for Meteorology, Hamburg, Germany \\ *now at: Eurasia Institute of Earth Sciences, Istanbul Technical University, Turkey
}

Received: 10 March 2011 - Published in Atmos. Chem. Phys. Discuss.: 30 March 2011

Revised: 12 August 2011 - Accepted: 29 August 2011 - Published: 16 September 2011

\begin{abstract}
Understanding historical trends of trace gas and aerosol distributions in the troposphere is essential to evaluate the efficiency of existing strategies to reduce air pollution and to design more efficient future air quality and climate policies. We performed coupled photochemistry and aerosol microphysics simulations for the period 1980-2005 using the aerosol-chemistry-climate model ECHAM5-HAMMOZ, to assess our understanding of long-term changes and interannual variability of the chemical composition of the troposphere, and in particular of ozone and sulfate concentrations, for which long-term surface observations are available. In order to separate the impact of the anthropogenic emissions and natural variability on atmospheric chemistry, we compare two model experiments, driven by the same ECMWF re-analysis data, but with varying and constant anthropogenic emissions, respectively. Our model analysis indicates an increase of ca. 1 ppbv $\left(0.055 \pm 0.002 \mathrm{ppbv} \mathrm{yr}^{-1}\right)$ in global average surface $\mathrm{O}_{3}$ concentrations due to anthropogenic emissions, but this trend is largely masked by the larger $\mathrm{O}_{3}$ anomalies due to the variability of meteorology and natural emissions. The changes in meteorology (not including stratospheric variations) and natural emissions account
\end{abstract}

for the $75 \%$ of the total variability of global average surface $\mathrm{O}_{3}$ concentrations. Regionally, annual mean surface $\mathrm{O}_{3}$ concentrations increased by 1.3 and $1.6 \mathrm{ppbv}$ over $\mathrm{Eu}-$ rope and North America, respectively, despite the large anthropogenic emission reductions between 1980 and 2005. A comparison of winter and summer $\mathrm{O}_{3}$ trends with measurements shows a qualitative agreement, except in North America, where our model erroneously computed a positive trend. Simulated $\mathrm{O}_{3}$ increases of more than $4 \mathrm{ppbv}$ in East Asia and 5 ppbv in South Asia can not be corroborated with long-term observations. Global average sulfate surface concentrations are largely controlled by anthropogenic emissions. Globally natural emissions are an important driver determining AOD variations. Regionally, AOD decreased by $28 \%$ over Europe, while it increased by $19 \%$ and $26 \%$ in East and South Asia. The global radiative perturbation calculated in our model for the period 1980-2005 was rather small $\left(0.05 \mathrm{~W} \mathrm{~m}^{-2}\right.$ for $\mathrm{O}_{3}$ and $0.02 \mathrm{~W} \mathrm{~m}^{-2}$ for total aerosol direct effect), but larger perturbations ranging from -0.54 to $1.26 \mathrm{~W} \mathrm{~m}^{-2}$ are estimated in those regions where anthropogenic emissions largely varied.

\section{Correspondence to: F. Dentener}

(frank.dentener@jrc.ec.europa.eu)

Published by Copernicus Publications on behalf of the European Geosciences Union. 


\section{Introduction}

Air quality is determined by the emission of primary pollutants into the atmosphere, by chemical production of secondary pollutants and by meteorological conditions. The two air pollutants of most concern for public health, ozone $\left(\mathrm{O}_{3}\right)$ and particulate matter (PM), have also strong impacts on climate. In the fourth Assessment Report of the Intergovernmental Panel on Climate Change (IPCC AR4), Solomon et al. (2007) estimate a Radiative Forcing (RF) from tropospheric ozone of $+0.35[-0.1,+0.3] \mathrm{W} \mathrm{m}^{-2}$, which corresponds to the third largest contribution to the total RF after carbon dioxide $\left(\mathrm{CO}_{2}\right)$ and methane $\left(\mathrm{CH}_{4}\right)$. IPCC AR4 also provides estimates for radiative forcing from aerosols. The direct RF (scattering and absorption of solar and infrared radiation) amounts to $-0.5[ \pm 0.4] \mathrm{W} \mathrm{m}^{-2}$, and the $\mathrm{RF}$ through indirect changes in cloud properties is estimated to -0.70 $[-1.1,+0.4] \mathrm{W} \mathrm{m}^{-2}$.

Trends in global radiation and visibility measurements indeed suggest an important role of aerosols. Solar radiation measurements showed a consistent and worldwide decrease at the Earth's surface (an effect dubbed "dimming") from the 1960s. This trend reversed into "brightening" in the late 1990s in the US, Europe and parts of Korea (Wild, 2009). Similarly, an analysis of visibility measurements from 1973-2007 by Wang et al. (2009) suggests a global increase of AOD worldwide, except in Europe. Since, $\mathrm{SO}_{4}^{2-}$ is one of the main aerosol components that determine the aerosol optical depth (Streets et al., 2009), the $\mathrm{SO}_{4}^{2-}$ concentration reductions over Europe and US after the implementation of air quality policies may partly explain the dimming-brightening transition observed in the 1990s in Europe, whereas in emerging economies such as China and India the emission of air pollutants rapidly increased since 1990.

Inter-annual meteorological variability in the last decades also strongly determined the variations of the concentrations and geographical distribution of air pollutants. For example, the El Niño event in 1997-1998 and the period after the Mt. Pinatubo volcanic eruption in 1991 can explain much of the past chemical inter-annual variability of tropospheric $\mathrm{O}_{3}$, $\mathrm{CH}_{4}$ and $\mathrm{OH}$ (Fiore et al., 2009; Dentener et al., 2003; Hess and Mahowald, 2009). In Europe, the infamous summer of 2003 led to a strong positive anomaly of solar surface radiation (Wild, 2009) and exacerbated ozone pollution at groundlevel and throughout the troposphere (Solberg et al., 2008; Tressol et al., 2008).

Meteorological variability and changes in the precursor emissions of $\mathrm{O}_{3}$ and $\mathrm{SO}_{4}^{2-}$ are often concurrent processes, and their impact on surface concentrations is difficult to understand from measurements alone (Vautard et al., 2006; Berglen et al., 2007). Therefore, there have been several efforts to re-analyze these trends using tropospheric chemistry and transport models. For example, the European project REanalysis of the TROpospheric chemical composi- tion (RETRO, Schultz et al., 2007) employed three different global models to simulate tropospheric ozone changes between 1960 and 2000. Recently Hess and Mahowald (2009) analyzed the role of meteorology in inter-annual variability of tropospheric ozone chemistry.

In this paper, we extend these analyses by using a coupled aerosol-chemistry-climate simulation, and discuss our results in the light of the previous studies. We analyze the chemical variability due to changes in meteorology (i.e. transport, chemistry) and natural emissions, and separate them from anthropogenic emissions induced variability. The period 19802005 was chosen because the advent of satellite observations in the 1970s introduced a discontinuity in the re-analysis of meteorological datasets (Hess and Mahowald, 2009; van Noije et al., 2006) and, as mentioned above, the considered period includes large meteorological anomalies. Particular attention will be given to four regions of the world (North America, Europe, East Asia, and South Asia) where significant changes in terms of the absolute amount of emitted trace gases and aerosol precursors occurred in the last decades. We will focus on past changes of $\mathrm{O}_{3}$ and $\mathrm{SO}_{4}^{2-}$ because of their importance for air quality and climate. Long measurement records are available since the 1980s and they will be used to evaluate our model results and the simulated trends. We further analyze changes in AOD, radiative perturbation (RP) and $\mathrm{OH}$ radical associated with changes in emissions and meteorology.

The paper is organized as follows. In Sect. 2 the model description and experiment setup are outlined. In Sect. 3 anthropogenic and natural emissions are described. Sections 4 and 5 present an analysis of global and regional variability and trends of $\mathrm{O}_{3}$ and $\mathrm{SO}_{4}^{2-}$ from 1980 to 2005 . The regional analysis focuses on Europe (EU), North America (NA), East Asia (EA), and South Asia (SA) (Fig. 1, the region boundaries were defined as in the HTAP study, Fiore et al., 2009). In Sect. 6 we will describe the anthropogenic radiative perturbation due to changes in $\mathrm{O}_{3}$ and $\mathrm{SO}_{4}^{2-}$. In Sects. 7 and 8 we will summarize the main findings and further discuss implications of our study for air quality-climate interactions.

\section{Model and simulation descriptions}

ECHAM5-HAMMOZ is a fully coupled aerosol-chemistryclimate model, composed of the general circulation model (GCM) ECHAM5, the tropospheric chemistry module MOZ, and the aerosol module HAM. The ECHAM5-HAMMOZ model is described in detail in Pozzoli et al. (2008a). The model has been extensively evaluated in previous studies (Stier et al., 2005; Pozzoli et al., 2008a,b; Auvray et al., 2007; Rast et al., 2011) with comparisons to several measurements and within model inter-comparison studies. We further remark a substantial overestimate of our computed ozone compared to measurements, a problem that ECHAM5- 


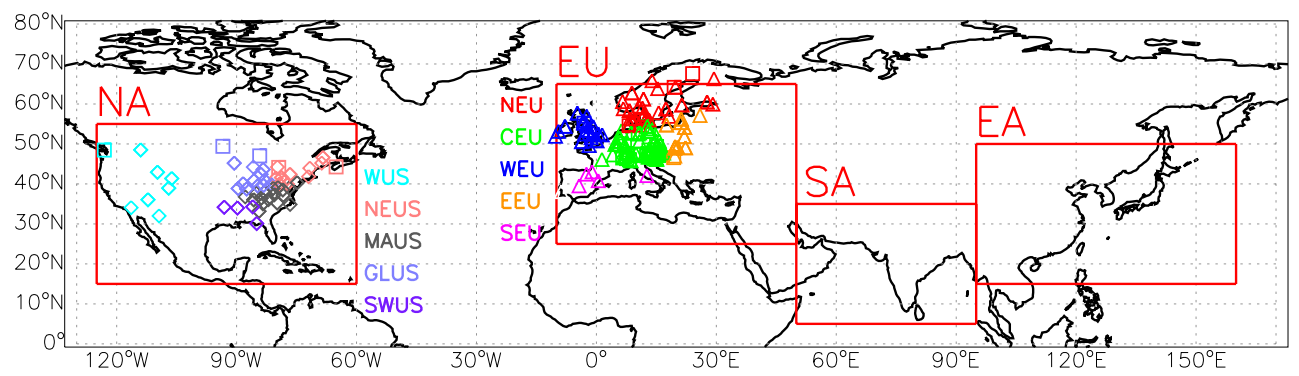

Fig. 1. Map of the selected regions for the analysis and measurement stations with long records of $\mathrm{O}_{3}$ and $\mathrm{SO}_{4}^{2-}$ surface concentrations. North America (NA) $\left[15^{\circ} \mathrm{N}-55^{\circ} \mathrm{N} ; 60^{\circ} \mathrm{W}-125^{\circ} \mathrm{W}\right.$, Europe (EU) $\left[25^{\circ} \mathrm{N}-65^{\circ} \mathrm{N} ; 10^{\circ} \mathrm{W}-50^{\circ} \mathrm{E}\right]$, East Asia (EA) $\left[15^{\circ} \mathrm{N}-50^{\circ} \mathrm{N}\right.$; $95^{\circ} \mathrm{E}-$ $\left.\left.160^{\circ} \mathrm{E}\right)\right]$, and South Asia (SA) $\left[5^{\circ} \mathrm{N}-35^{\circ} \mathrm{N} ; 50^{\circ} \mathrm{E}-95^{\circ} \mathrm{E}\right]$. Triangles show the location of EMEP stations, squares of WDCGG stations, and diamonds of CASTNET stations. The stations are grouped in sub-regions: Northern Europe (NEU); Central Europe (CEU); Western Europe (WEU); Eastern Europe (EEU); Southern Europe (SEU); Western US (WUS): North-Eastern US (NEUS); Mid-Atlantic US (MAUS); Great lakes US (GLUS); Southern US (SUS).

HAMMOZ shares with many other global models and we refer for a further discussion to Ellingsen et al. (2008).

In this study a triangular truncation at wavenumber 42 (T42) resolution was used for the computation of the general circulation. Physical variables are computed on an associated Gaussian grid with a horizontal resolution of ca. $2.8^{\circ} \times 2.8^{\circ}$ degrees. The model has 31 vertical levels from the surface up to $10 \mathrm{hPa}$ and a time resolution for dynamics and chemistry of $20 \mathrm{~min}$. We simulated the period 1979-2005 (the first year is discarded from the analysis as spin-up). Meteorology was taken from the ECMWF ERA-40 re-analysis (Uppala et al., 2005) until 2000 and from operational analyses (IFS cycle-32r2) for the remaining period (2001-2005). Even though we do not find any evidence for this we must note that this discontinuity may have an impact on the meteorological variables and therefore on our analysis in the last years of the simulated period. Such discontinuities may also arise within a re-analysis data set due to the inclusion of different data sets in the assimilation procedure. ECHAM5 vorticity, divergence, sea surface temperature, and surface pressure are relaxed towards the re-analysis data every time step with a relaxation time scale of 1 day for surface pressure and temperature, 2 days for divergence, and $6 \mathrm{~h}$ for vorticity (Jeuken et al., 1996). The relaxation technique forces the large scale dynamic state of the atmosphere as close as possible to the re-analysis data, thus the model is in a consistent physical state at each time step but it calculates its own physics, e.g. for aerosols and clouds. The concentrations of $\mathrm{CO}_{2}$ and other GHGs, used to calculate the radiative budget, were set according to the specifications given in Appendix II of the IPCC TAR report (Nakicenovic et al., 2000). In Appendix A we provide a detailed description of the chemical and microphysical parameterizations included in ECHAM5HAMMOZ. A detailed description of the ECHAM5 model can be found in Roeckner et al. (2003).
Two transient simulations were conducted:

- SREF: reference simulation for 1980-2005 where meteorology and emissions are changing on an hourly-tomonthly basis;

- SFIX: simulation for 1980-2005 with anthropogenic emissions fixed at year 1980, while meteorology, natural and wildfire emissions change as in SREF.

\section{Emissions}

\subsection{Anthropogenic emissions}

The anthropogenic emissions of $\mathrm{CO}, \mathrm{NO}_{\mathrm{x}}$, and VOCs for the period 1980-2000 are taken from the RETRO inventory (http://retro.enes.org/) (Schultz et al., 2007; Endresen et al., 2003; Schultz et al., 2008) which provides monthly average emission fields interpolated to the model resolution of $2.8^{\circ} \times 2.8^{\circ}$. In order to prevent a possible drift in $\mathrm{CH}_{4}$ concentrations with consequences for the simulation of $\mathrm{OH}$ and $\mathrm{O}_{3}$, we prescribed monthly zonal mean $\mathrm{CH}_{4}$ concentrations in the boundary layer obtained from the interpolation of surface measurements (Schultz et al., 2007). The prescribed $\mathrm{CH}_{4}$ concentrations vary annually and range from 1520-1650 ppbv (Southern and Northern Hemisphere, respectively SH and $\mathrm{NH}$ ) in 1980 to 1720 $1860 \mathrm{ppbv}$ in 2005 ( $\mathrm{SH}$ and $\mathrm{NH}) . \mathrm{NO}_{\mathrm{x}}$ aircraft emissions are based on Grewe et al. (2001) and distributed according to prescribed height profiles. The AeroCom hindcast aerosol emission inventory (http://dataipsl.ipsl.jussieu. fr/AEROCOM/emissions.html) was used for the annual total anthropogenic emissions of primary black carbon (BC), organic carbon $(\mathrm{OC})$ aerosols and sulfur dioxide $\left(\mathrm{SO}_{2}\right)$. Specifically, the detailed global inventory of primary $\mathrm{BC}$ and $\mathrm{OC}$ emissions by Bond et al. (2004) was modified by Streets et al. $(2004,2006)$ to include additional technologies and new fuel attributes to calculate $\mathrm{SO}_{2}$ emissions using the same energy 
drivers as for BC and OC, and extended to the period 19802006 (Streets et al., 2009) using annual fuel-use trends and economic growth parameters included in the IMAGE model (National Institute for Public Health and the Environment, 2001). Except for biomass burning, the $\mathrm{BC}, \mathrm{OC}$, and $\mathrm{SO}_{2}$ anthropogenic emissions were provided as annual averages. Primary emissions of $\mathrm{SO}_{4}^{2-}$ are calculated as constant fraction $(2.5 \%)$ of the anthropogenic sulfur emissions. The $\mathrm{SO}_{2}$ and primary $\mathrm{SO}_{4}^{2-}$ emissions from international ship traffic for the years 1970, 1980, 1995, and 2001, were based on the EDGAR 2000 FT inventory (van Aardenne et al., 2001) and linearly interpolated in time, using total emission estimates from Eyring et al. $(2005 \mathrm{a}, \mathrm{b})$. The emissions of $\mathrm{CO}, \mathrm{NO}_{\mathrm{x}}$, and VOCs were available only until the year 2000 . Therefore, we used for 2001-2005 the 2000 emissions, except for the regions where significant changes were expected between 2000 and 2005, such as US, Europe, East Asia and South East Asia (defined as in Fig. 1), for which derived emission trends of $\mathrm{CO}, \mathrm{NO}_{\mathrm{x}}$, and VOCs were applied to year 2000 . The emission ratios between the period 2001-2005 and the year 2000 from the USEPA (http://www.epa.gov/ttn/chief/ trends/), EMEP (http://www.emep.int/), and REAS (http: //www.jamstec.go.jp/frcgc/research/p3/emission.htm) emission inventories were applied to year 2000 emissions used for this study over the US, Europe, and Asia.

Table 1 summarizes the total annual anthropogenic emissions for the years 1980, 1985, 1990, 1995, 2000, and 2005. Global emissions of CO, VOCs and BC were relatively constant during the last decades, with small increases between 1980 and 1990, decreases in the 1990s and renewed increase between 2000 and 2005. During these $25 \mathrm{yr}$, global $\mathrm{NO}_{\mathrm{x}}$ and OC emissions increased up to $10 \%$, while sulfur emissions decreased by $10 \%$. However, these global numbers mask that the global distribution of the emission largely changed, with reductions over North America and Europe, balanced by strong increases in the economically emerging countries, such as China and India. Figure 2 shows the relative trends of anthropogenic emissions used during this study over the 4 selected world regions. In Europe and North America there is a general decrease of emissions of all pollutants from 1990 on. In East Asia and South Asia anthropogenic emissions generally increase although for EA there is a decrease around 2000.

For the period 1980-2000, our global amounts of emission from anthropogenic sources, which are based on RETRO, are lower by more than $10 \%$ for $\mathrm{CO}$ and $\mathrm{NO}_{\mathrm{x}}$, and they are higher by more than $40 \%$ for VOCs, when compared to the new emission inventory prepared by Lamarque et al. (2010) in support of the Intergovernmental Panel on Climate Change (IPCC) Fifth Assessment Report (AR5). For the period 2001-2005 several studies have recently shown significant changes in regional emissions, especially in Asia (e.g. Richter et al. (2005); Zhang et al. (2009); Klimont et al. (2009)). In our study, compared to the projection for year 2005 of Lamarque et al. (2010), which includes the refer-
Table 1. Global anthropogenic emissions of $\mathrm{CO}\left[\mathrm{Tg} \mathrm{yr}^{-1}\right]$, $\mathrm{NO}_{\mathrm{x}}\left[\mathrm{Tg}(\mathrm{N}) \mathrm{yr}^{-1}\right]$, VOCs $\left[\mathrm{Tg}(\mathrm{C}) \mathrm{yr}^{-1}\right], \mathrm{SO}_{2}\left[\mathrm{Tg}(\mathrm{S}) \mathrm{yr}^{-1}\right], \mathrm{SO}_{4}{ }^{2-}$ $\left[\mathrm{Tg}(\mathrm{S}) \mathrm{yr}^{-1}\right], \mathrm{OC}\left[\mathrm{Tg} \mathrm{yr}^{-1}\right]$, and BC $\left[\mathrm{Tg} \mathrm{yr}^{-1}\right]$.

\begin{tabular}{lrrrrrr}
\hline & 1980 & 1985 & 1990 & 1995 & 2000 & 2005 \\
\hline $\mathrm{CO}$ & 673.7 & 680.1 & 713.8 & 685.3 & 655.4 & 678.6 \\
$\mathrm{NO}_{\mathrm{x}}$ & 34.2 & 33.7 & 36.1 & 36.4 & 36.7 & 37.2 \\
$\mathrm{VOCs}$ & 84.6 & 85.0 & 87.9 & 84.8 & 80.5 & 84.3 \\
$\mathrm{SO}_{2}$ & 67.1 & 67.2 & 66.2 & 61.0 & 58.8 & 59.0 \\
$\mathrm{SO}_{4}{ }^{2-}$ & 1.8 & 1.8 & 1.8 & 1.7 & 1.6 & 1.6 \\
$\mathrm{OC}$ & 7.8 & 8.2 & 8.3 & 8.7 & 8.5 & 8.7 \\
$\mathrm{BC}$ & 4.9 & 4.9 & 4.9 & 4.8 & 4.7 & 4.9 \\
\hline
\end{tabular}

ences cited above, we applied: significantly lower emission reductions between 1980 and 2005 for $\mathrm{CO}$ and $\mathrm{SO}_{2}$ in $\mathrm{EU}$; larger reductions for $\mathrm{BC}$ and $\mathrm{OC}$ in both $\mathrm{EU}$ and $\mathrm{NA}$; lower emission changes except for $\mathrm{CO}$ in EA; similar emission changes except for $\mathrm{NO}_{\mathrm{x}}$ and $\mathrm{SO}_{2}$ in $\mathrm{SA}$ (Fig. 2).

\subsection{Natural and biomass burning emissions}

Some $\mathrm{O}_{3}$ and $\mathrm{SO}_{4}^{2-}$ precursors are emitted by natural processes, which exhibit inter-annual variability due to changing meteorological parameters (temperature, wind, solar radiation, clouds and precipitation). For example, VOC emissions from vegetation are influenced by surface temperature and short wavelength radiation, $\mathrm{NO}_{\mathrm{x}}$ is produced by lightning and associated with convective activity, dimethyl sulfide (DMS) emissions depend on the phytoplankton blooms in the oceans and wind speed, and some aerosol species, such as mineral dust and sea salt, are strongly dependent on surface wind speed. Inter-annual variability of weather will therefore influence the concentrations of tropospheric $\mathrm{O}_{3}$ and $\mathrm{SO}_{4}^{2-}$ and may also affect the radiative budget. The emissions from vegetation of $\mathrm{CO}$ and VOCs (isoprene and terpenes) were calculated interactively using the Model of Emissions of Gases and Aerosols from Nature (MEGAN) (Guenther et al., 2006). The total annual natural emissions in $\operatorname{Tg}(C)$ of CO and biogenic VOCs (BVOCs) for the period 19802005 range from 840 to $960 \mathrm{Tg}(\mathrm{C}) \mathrm{yr}^{-1}$ with a standard deviation of $26 \mathrm{Tg}(\mathrm{C}) \mathrm{yr}^{-1}$ (Fig. 3a), which corresponds to $3 \%$ of the annual mean natural VOC emissions for the considered period. $80 \%$ of these total biogenic emissions occur in the tropics.

Lightning $\mathrm{NO}_{\mathrm{x}}$ emissions (Fig. 3b) are calculated following the parameterization of Grewe et al. (2001). We calculated a $5 \%$ variability for $\mathrm{NO}_{\mathrm{x}}$ emissions from lightning, from 3.55 to $4.25 \mathrm{Tg}(\mathrm{N}) \mathrm{yr}^{-1}$, with a decreasing trend of $0.017 \mathrm{Tg}(\mathrm{N}) \mathrm{yr}^{-1}\left(R^{2}\right.$ of $0.53 ; 95 \%$ confidence bounds \pm 0.007$)$. We note here that there are considerable uncertainties in the parameterization of $\mathrm{NO}_{\mathrm{x}}$ emissions (e.g. Grewe et al., 2001; Tost et al., 2007; Schumann and Huntrieser, 2007), and different parameterizations simulated 
opposite trends over the same period (Schultz et al., 2007). An annual constant contribution of $9.3 \mathrm{Tg}(\mathrm{N}) \mathrm{yr}^{-1}$ is included in our simulations for $\mathrm{NO}_{\mathrm{x}}$ emissions from microbial activity in soils (Schultz et al., 2007).

DMS, predominantly emitted from the oceans, is an $\mathrm{SO}_{4}^{2-}$ aerosol precursor. Its emissions depend on seawater DMS concentrations associated with phytoplankton blooms (Kettle and Andreae, 2000) and model surface wind speed, which determines the DMS sea-air exchange (Nightingale et al., 2000). Terrestrial biogenic DMS emissions follow Pham et al. (1995). The total DMS emissions are ranging from 22.7 to $24.4 \mathrm{Tg}(\mathrm{S}) \mathrm{yr}^{-1}$, with a standard deviation of $0.3 \mathrm{Tg}(\mathrm{S}) \mathrm{yr}^{-1}$ or $1 \%$ of annual mean emissions (Fig. 3c). The highest DMS emissions correspond to the 1997-1998 ENSO event. Since we have used a climatology of seawater DMS concentrations instead of annually varying concentrations, the variability may be misrepresented.

The emissions of sea salt are based on Schulz et al. (2004). The strong dependency on wind speed results in a range from $5000-5550 \mathrm{Tg} \mathrm{yr}^{-1}$ (Fig. 3e) with a standard deviation of $2 \%$.

Mineral dust emissions are calculated online using the ECHAM5 wind speed, hydrological parameters (e.g. soil moisture), and soil properties, following the work of Tegen et al. (2002) and Cheng et al. (2008). The total mineral dust emissions have a large inter-annual variability (Fig. 3d), ranging from 620 to $930 \mathrm{Tg} \mathrm{yr}^{-1}$, with a standard deviation of $72 \mathrm{Tg} \mathrm{yr}^{-1}$, almost $10 \%$ of the annual mean average. Mineral dust originating from the Sahara and over Asia contribute on average $58 \%$ and $34 \%$ to the global mineral dust emissions, respectively.

Biomass burning, from tropical savannah burning, deforestation fires, and mid-and high latitude forest fires are largely linked to anthropogenic activities but fire severity (and hence emissions) are also controlled by meteorological factors such as temperature, precipitation and wind. We use the compilation of inter-annual varying biomass burning emissions published by Schultz et al. (2008), who used literature data, satellite observations and a dynamical vegetation model in order to obtain continental-scale emission estimates and a geographical distribution of fire occurrence. We consider emissions of the components $\mathrm{CO}, \mathrm{NO}_{\mathrm{x}}, \mathrm{BC}$, OC, and $\mathrm{SO}_{2}$, and apply a time-invariant vertical profile of the plume injection height for forest and savannah fire emissions. Figure $3 f$ shows the inter-annual variability for $\mathrm{CO}, \mathrm{NO}_{\mathrm{x}}$, and OC biomass burning emissions, with different peaks, such as in year 1998 during the strong ENSO episode.

Other natural emissions are kept constant during the entire simulation period. $\mathrm{CO}$ emissions from soil and ocean are based on the Global Emission Inventory Activity (GEIA) as in Horowitz et al. (2003), amounting to 160 and $20 \mathrm{Tg} \mathrm{yr}^{-1}$, respectively. Natural soil $\mathrm{NO}_{\mathrm{x}}$ emissions are taken from the ORCHIDEE model (Lathiere et al., 2006), resulting in $9 \mathrm{Tg}(\mathrm{N}) \mathrm{yr}^{-1} \cdot \mathrm{SO}_{2}$ volcanic emissions of $14 \mathrm{Tg}(\mathrm{S}) \mathrm{yr}^{-1}$ are from Andres and Kasgnoc (1998) and Halmer et al. (2002).
Since in the current model version secondary organic aerosol (SOA) formation is not calculated online, we applied a monthly varying OC emission $\left(19 \mathrm{Tg} \mathrm{yr}^{-1}\right)$ to take into account the SOA production from biogenic monoterpenes (a factor of 0.15 is applied to monoterpene emissions of Guenther et al., 1995), as recommended in the AEROCOM project (Dentener et al., 2006).

\section{Variability and trends of $\mathrm{O}_{3}$ and $\mathrm{OH}$ during 1980-2005 and their relationship to meteorological variables}

In this section we analyze the global and regional variability of $\mathrm{O}_{3}$ and $\mathrm{OH}$ in relation to selected modeled chemical and meteorological variables. Section 4.1 will focus on global surface ozone, Sect. 4.2 will look into more detail to regional differences in $\mathrm{O}_{3}$, and for Europe and the US, compare the data to observations. Section 4.3 will describe the variability of the global ozone budget, and Sect. 4.4 will focus on the related changes in $\mathrm{OH}$. As explained earlier, we will separate the influence of meteorological and natural emission variability from anthropogenic emissions by differencing the SREF and SFIX simulations.

\subsection{Global surface ozone and relation to meteorological variability}

In Fig. 4 we show the ECHAM5-HAMMOZ SREF interannual monthly anomalies (difference between the monthly value and the 25-yr monthly average) of global mean surface temperature, water vapor, and surface concentrations of $\mathrm{O}_{3}$. $\mathrm{SO}_{4}^{2-}$, total column AOD and methane-weighted $\mathrm{OH}$ tropospheric concentrations will be discussed in later sections. To better visualize the inter-annual variability over 1980-2005, in Fig. 4, we also display the 12-months running average of monthly mean anomalies for both SREF (blue) and SFIX (red) simulations.

Surface temperature evolution showed large anomalies in the last decades, associated with major natural events. For example, large volcanic eruptions (El Chichon, 1982; Mt. Pinatubo, 1991) generated cooler temperatures due to the emission into the stratosphere of sulfate aerosols. The 19971998 ENSO caused an increase in temperature of ca. $0.4 \mathrm{~K}$. The strong coupling of the hydrological cycle and temperature is reflected in a correlation of 0.83 between the monthly anomalies of global surface temperature and water vapor content. These two meteorological variables influence $\mathrm{O}_{3}$ and OH concentrations. For example the large 1997-1998 ENSO event corresponds with a positive ozone anomaly of more than 2 ppbv. There is also an evident correspondence between lower ozone and cooler periods in 1984 and 1988. However, the correlation between monthly temperature and $\mathrm{O}_{3}$ anomalies (in SFIX) is only moderate $(R=0.43)$. 

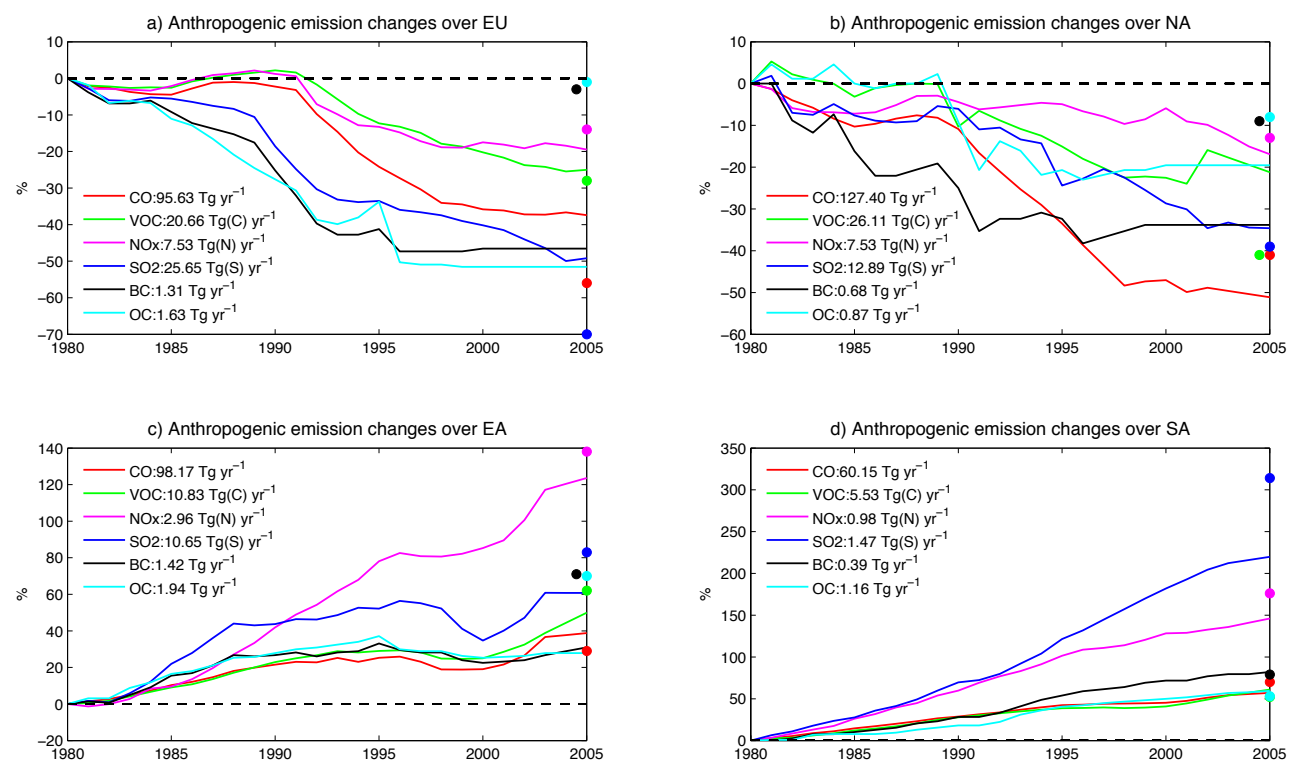

Fig. 2. Percentage changes in total anthropogenic emissions (CO, VOC, $\mathrm{NO}_{\mathrm{x}}, \mathrm{SO}_{2}, \mathrm{BC}$ and $\mathrm{OC}$ ) from 1980 to 2005 over the four selected regions as shown in Fig. 1: (a) Europe, EU; (b) North America, NA; (c) East Asia, EA; (d) South Asia, SA. In the legend of each regional plot, the total annual emissions for each species are reported for the year 1980. The colored points represent the percentage changes in regional emissions between 1980 and 2005 in Lamarque et al. (2010) which includes recent assessments in the projections for the year 2005.
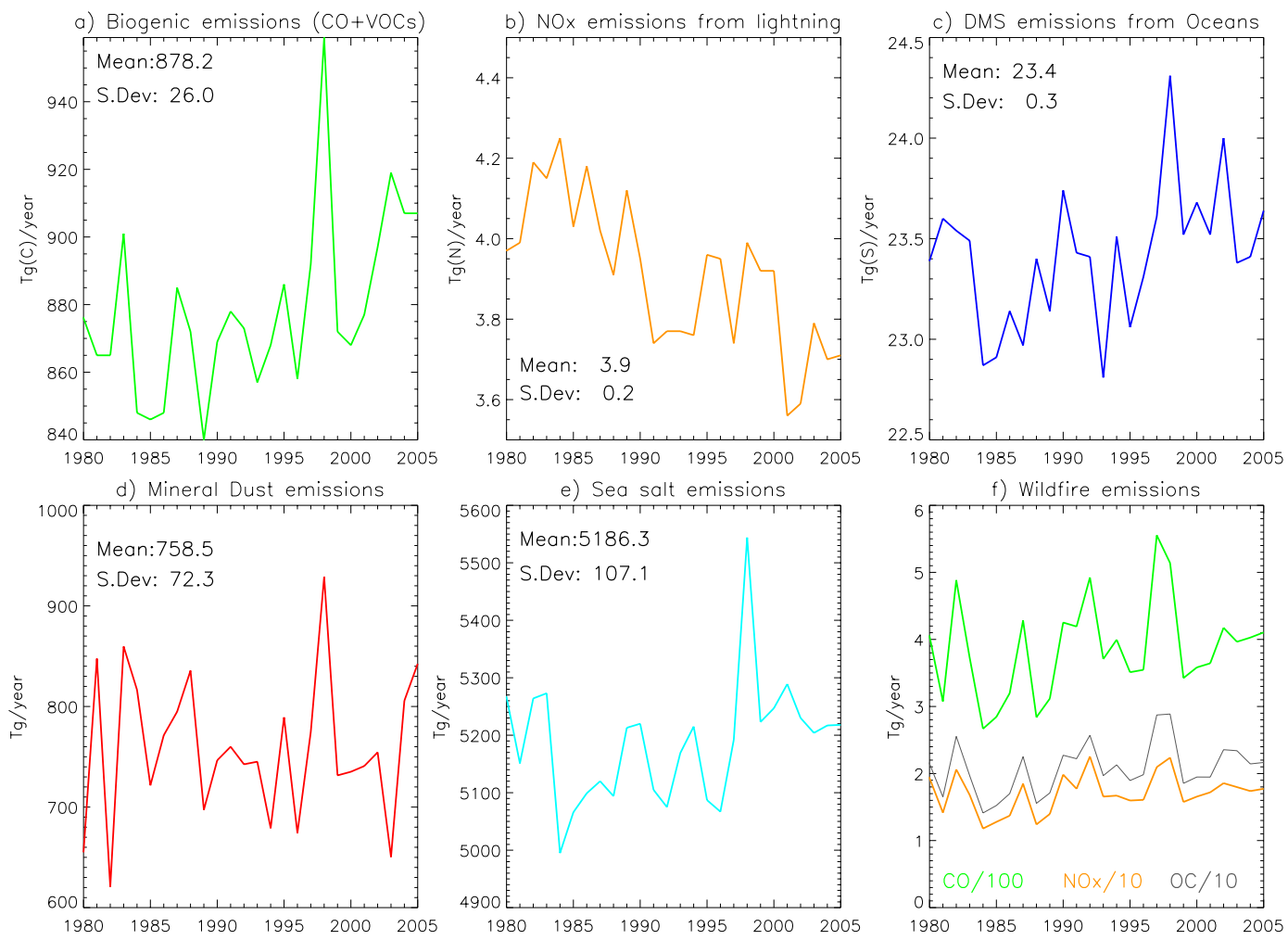

Fig. 3. Total annual natural and biomass burning emissions for the period 1980-2005: (a) biogenic CO and VOCs emissions from vegetation; (b) $\mathrm{NO}_{\mathrm{x}}$ emissions from lightning; (c) DMS emissions from oceans; (d) mineral dust aerosol emissions; (e) marine sea salt aerosol emissions; (f) $\mathrm{CO}, \mathrm{NO}_{\mathrm{x}}$, and $\mathrm{OC}$ aerosol biomass burning emissions. 
Table 2. Average, standard deviation (SD) and relative standard deviation (RSD, standard deviation divided by the mean) of globally averaged variables in this work for the simulation with changing anthropogenic emission and with fixed anthropogenic emissions (1980-2005). Three dimensional variables are density weighted and averaged between the surface and $280 \mathrm{hPa}$. Three dimensional quantities evaluated at the surface are prefixed with Sfc. The standard deviation is calculated as the standard deviation of the monthly anomalies (the monthly value minus the mean of all years for that month).

\begin{tabular}{|c|c|c|c|c|c|c|}
\hline & \multicolumn{3}{|c|}{ SREF } & \multicolumn{3}{|c|}{ SFIX } \\
\hline & Average & SD & RSD & Average & SD & RSD \\
\hline $\mathrm{Sfc}_{3}$ (ppbv) & 36.45 & 0.826 & 0.0227 & 35.97 & 0.627 & 0.0174 \\
\hline $\mathrm{O}_{3}(\mathrm{ppbv})$ & 48.37 & 1.1020 & 0.0228 & 47.64 & 0.8851 & 0.0186 \\
\hline $\mathrm{CO}(\mathrm{ppbv})$ & 0.103 & 0.000416 & 0.0402 & 0.101 & 0.000529 & 0.0519 \\
\hline $\mathrm{OH}\left(\right.$ molecules $\left.\mathrm{cm}^{-3} \times 10^{6}\right)$ & 1.20 & 0.016 & 0.013 & 1.18 & 0.029 & 0.024 \\
\hline $\mathrm{HNO}_{3}$ (pptv) & 129.11 & 14.70 & 0.1139 & 125.73 & 13.91 & 0.1106 \\
\hline $\operatorname{Emi~S}\left(\operatorname{Tg~yr}^{-1}\right)$ & 104.2 & 3.49 & 0.0336 & 108.09 & 0.47 & 0.0043 \\
\hline $\mathrm{SO}_{2}$ (pptv) & 231.7 & 15.02 & 0.0648 & 246.9 & 8.70 & 0.0352 \\
\hline $\mathrm{Sfc} \mathrm{SO}_{4}^{-2}\left(\mu \mathrm{g} \mathrm{m}^{-3}\right)$ & 1.12 & 0.071 & 0.0640 & 1.18 & 0.061 & 0.0515 \\
\hline $\mathrm{SO}_{4}^{-2}\left(\mu \mathrm{g} \mathrm{m}^{-3}\right)$ & 0.69 & 0.028 & 0.0406 & 0.72 & 0.025 & 0.0352 \\
\hline
\end{tabular}
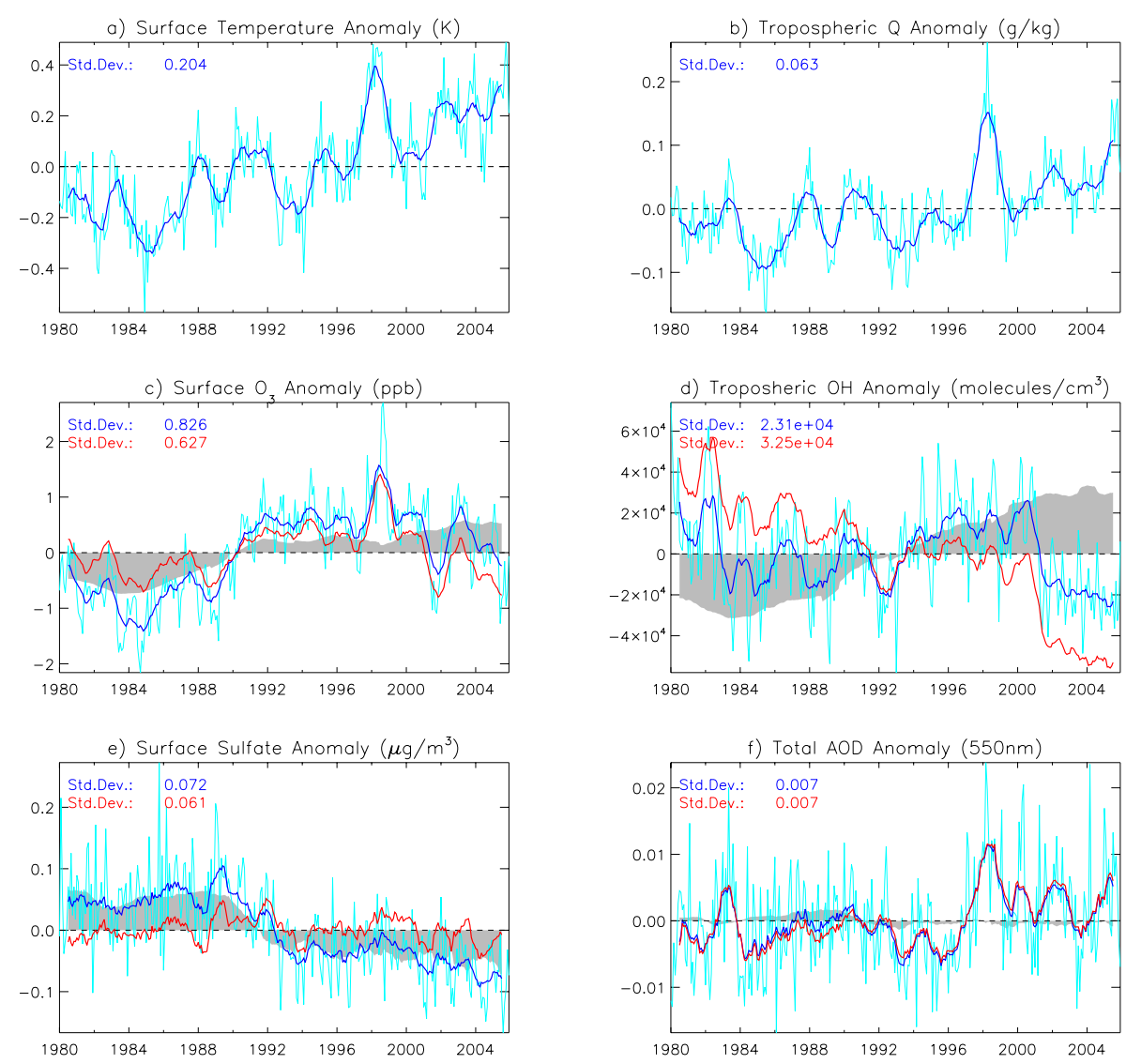

Fig. 4. Monthly mean anomalies for the period 1980-2005 of globally averaged fields for the SREF and SFIX ECHAM5-HAMMOZ simulations. Light blue lines are monthly mean anomalies for the SREF simulation, with overlaying dark blue giving the 12 month running averages. Red lines are the 12 month running averages of monthly mean anomalies for the SFIX simulation. The grey area represents the difference between SREF and SFIX. The global fields are respectively: (a) surface temperature (K); (b) tropospheric specific humidity $\left(\mathrm{g} \mathrm{Kg}^{-1}\right)$; (c) $\mathrm{O}_{3}$ surface concentrations (ppbv); (d) $\mathrm{OH}$ tropospheric concentration weighted by $\mathrm{CH}_{4}$ reaction $\left(\right.$ molecules cm $^{-3}$ ); $(\mathbf{e}) \mathrm{SO}_{4}^{2-}$ surface concentrations $\left(\mu \mathrm{g} \mathrm{m}^{-3}\right)$; (f) total aerosol optical depth. 

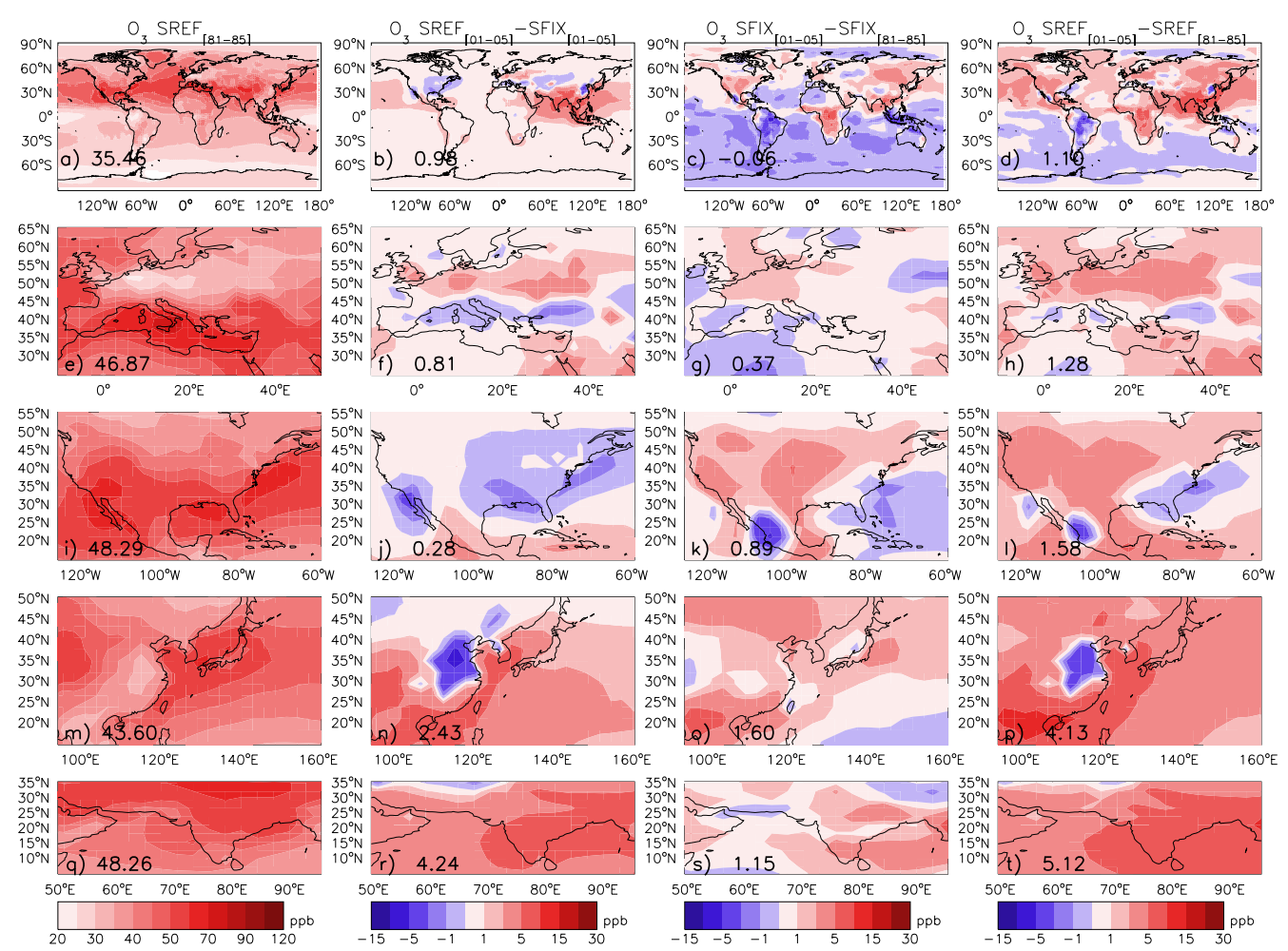

Fig. 5. Maps of surface $\mathrm{O}_{3}$ concentrations and the changes due to anthropogenic emissions and natural variability. In the first column we show $5 \mathrm{yr}$ averages (1981-1985) of surface $\mathrm{O}_{3}$ concentrations over the selected regions, Europe, North America, East Asia, and South Asia. In the second column (b) we show the effect of anthropogenic emission changes in the period 2001-2005 on surface $\mathrm{O}_{3}$ concentrations, calculated as the difference between SREF and SFIX simulations. In the third column (c) the natural variability of $\mathrm{O}_{3}$ concentrations is shown, which is due to natural emissions and meteorology in the simulated $25 \mathrm{yr}$, calculated as the difference between the $5 \mathrm{yr}$ average periods (2001-2005) and (1981-1985) in the SFIX simulation. The combined effect of anthropogenic emissions and natural variability is shown in column (d) and it is expressed as the difference between the $5 \mathrm{yr}$ average period (2001-2005)-(1981-1985) in the SREF simulation.

The 25 -yr global surface $\mathrm{O}_{3}$ average is $36.45 \mathrm{ppbv}$ (Table 2) and increased by 0.48 ppbv compared to the SFIX simulation, with year 1980 constant anthropogenic emissions. About half of this increase is associated with anthropogenic emission changes (Fig. 4c (grey area)). The interannual monthly surface ozone concentrations varied by up to $\pm 2.17 \mathrm{ppbv}(1 \sigma=0.83 \mathrm{ppbv})$, of which $75 \%$ ( $0.63 \mathrm{ppbv}$ in SFIX) was related to natural variations- especially the 1997 1998 ENSO event.

\subsection{Regional differences in surface ozone trends, variability, and comparison to measurements}

Global trends and variability may mask contrasting regional trends. Therefore we also perform a regional analysis for North America (NA), Europe (EU), East Asia (EA) and South Asia (SA) (see Fig. 1). To quantify the impact on surface concentrations after $25 \mathrm{yr}$ of changing anthropogenic emission, we compare the averages of two 5-yr periods, 1981-1985 and 2001-2005. We considered 5-yr averages to reduce the noise due to meteorological variability in these two periods.
In Fig. 5 we provide maps for the globe, Europe, North America, East Asia and South Asia (rows), showing in the first column (a) the reference surface concentrations, and in the other 3 columns relative to the period 1981-1985, the isolated effect of anthropogenic emission changes (b), meteorological and natural emission changes (c), and combined changes (d). The global maps provide insight into interregional influences of concentrations.

A comparison to observed trends provides additional insight into the accuracy of our calculations (Fig. 6). This comparison, however, is hampered by the lack of observations before 1990, and the lack of long-term observations outside of Europe and North America. We will therefore limit the comparison to the period 1990-2005, separately for winter (DJF) and summer (JJA), acknowledging that some of the larger changes may have happened before. Figure 1 displays the measurement locations: we used 53 stations in North America and 98 stations in Europe. To allow a realistic comparison with our coarse-resolution model, we grouped the measurement in 5 subregions for EU and 5 subregions for NA. For each subregion we calculated the trend of the median winter and summer anomalies. In Appendix B we give an extensive 

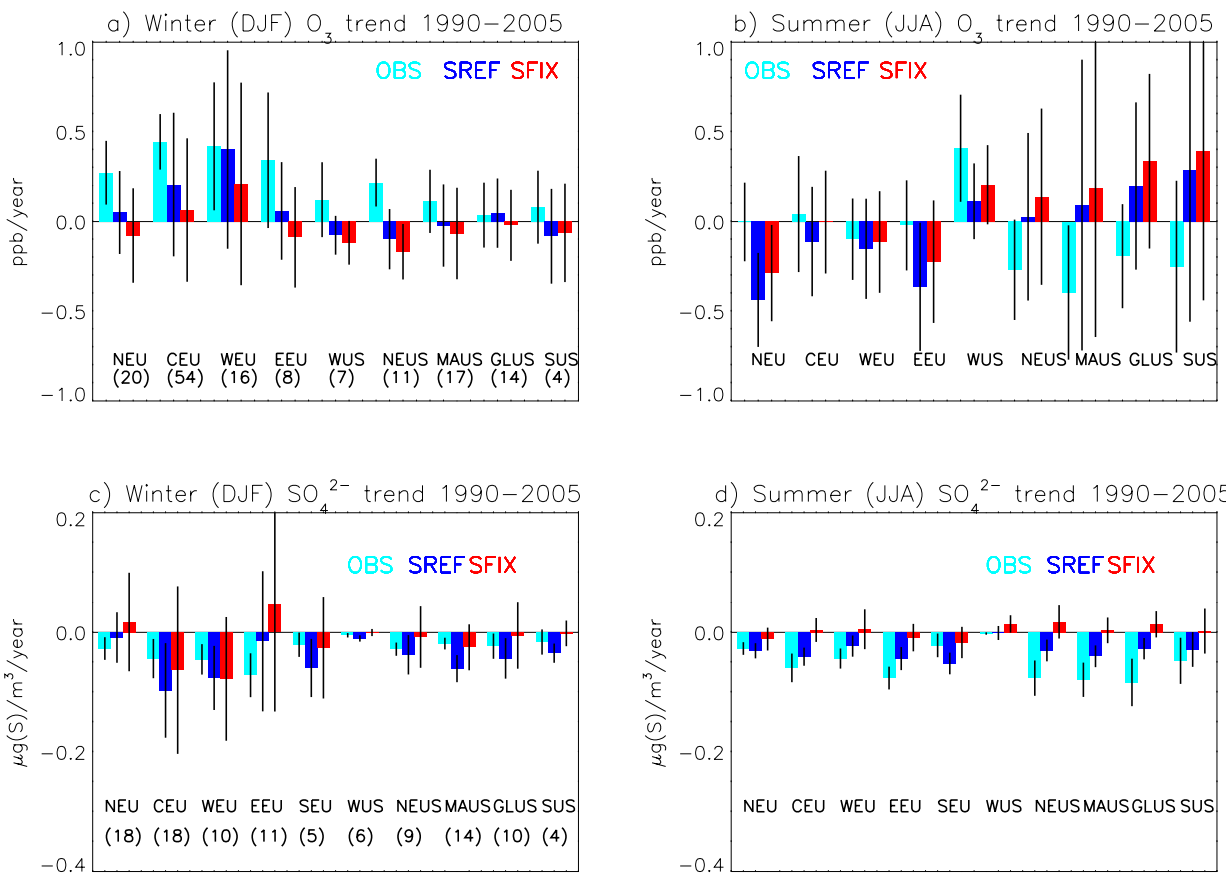

Fig. 6. Trends of the observed (OBS) and calculated (SREF and SIFX) $\mathrm{O}_{3}$ and $\mathrm{SO}_{4}^{2-}$ seasonal anomalies (DJF and JJA) averaged over each group of stations as shown in Fig. 1: Northern Europe (NEU); Central Europe (CEU); Western Europe (WEU); Eastern Europe (EEU); Southern Europe (SEU); Western US (WUS): North-Eastern US (NEUS); Mid-Atlantic US (MAUS); Great lakes US (GLUS); Southern US (SUS). The vertical bars represent the $95 \%$ confidence interval of the trends. The number of stations used to calculate the average seasonal anomalies for each subregion is shown in parentheses. Further details in Appendix B.

description of the data used for these summary figures, and their statistical comparison with model results.

We note here that $\mathrm{O}_{3}$ and $\mathrm{SO}_{4}^{2-}$ in ECHAM5-HAMMOZ were extensively evaluated in previous studies (Stier et al., 2005; Pozzoli et al., 2008a,b; Rast et al., 2011), showing in general a good agreement between calculated and observed $\mathrm{SO}_{4}^{2-}$ and an overestimation of surface $\mathrm{O}_{3}$ concentrations in some regions. We implicitly assume that this model bias does not influence the calculated variability and trends (Fig. B1 in Appendix B).

\subsubsection{Europe}

In Fig. 5e we show the SREF 1981-1985 annual mean EU surface $\mathrm{O}_{3}$ (i.e. before large emission changes) corresponding to an EU average concentration of $46.9 \mathrm{ppbv}$. High annual average $\mathrm{O}_{3}$ concentrations up to $70 \mathrm{ppbv}$ are found over the Mediterranean basin, and lower concentrations between 20 to $40 \mathrm{ppbv}$ in Central and Eastern Europe. Figure $5 \mathrm{f}$ shows the difference in mean $\mathrm{O}_{3}$ concentrations between the SREF and SFIX simulation for the period 2001-2005. The decline of $\mathrm{NO}_{\mathrm{x}}$ and VOC anthropogenic emissions was $20 \%$ and $25 \%$, respectively (Fig. 2a). Annual averaged surface $\mathrm{O}_{3}$ concentration increases by $0.81 \mathrm{ppbv}$ between $1981-1985$ and 2001-2005. The spatial distribution of the calculated trends shows a strong variation over Europe: the computed $\mathrm{O}_{3}$ increased between 1 and 5 ppbv over Northern and Cen- tral Europe, while it decreased by up to $1-5$ ppbv over Southern Europe. The $\mathrm{O}_{3}$ responses to emission reductions are driven by a complex nonlinear photochemistry of the $\mathrm{O}_{3}$, $\mathrm{NO}_{\mathrm{x}}$ and VOC system. Indeed, we can see very different $\mathrm{O}_{3}$ winter and summer sensitivities in Figs. 7a and 8. The increase (7\% compared to year 1980) in annual $\mathrm{O}_{3}$ surface concentration is mainly driven by winter (DJF) values, while in summer (JJA) there is a small $2 \%$ decrease between SREF and SFIX. This winter $\mathrm{NO}_{\mathrm{x}}$ titration effect on $\mathrm{O}_{3}$ is particularly strong over Europe (and less over other regions), as was also shown in e.g. Fig. 4 of Fiore et al. (2009), due to the relatively high $\mathrm{NO}_{\mathrm{x}}$ emission density, and the mid-to-high latitude location of Europe. The impact of changing meteorology and natural emissions over Europe is shown in Fig. $5 \mathrm{~g}$, showing an increase by 0.37 ppbv between 1981-1985 and 2001-2005. Winter-time variability drives much of the interannual variability of surface $\mathrm{O}_{3}$ concentrations (see Figs. 7a and 8a). While it is difficult to attribute the relationship between $\mathrm{O}_{3}$ and meteorological conditions to a single process, we speculate that the European surface temperature increase of $0.7 \mathrm{~K}$ from 1981-1985 to 2001-2005 could play a significant role. Figure 5d, 5h, and 51 show that modeled North Atlantic ozone increased during the same period, contributing to the increase of the baseline $\mathrm{O}_{3}$ concentrations at the western border of EU. Figure $5 \mathrm{f}$ and $5 \mathrm{~g}$ show that both emissions and meteorological variability may have synergistically 

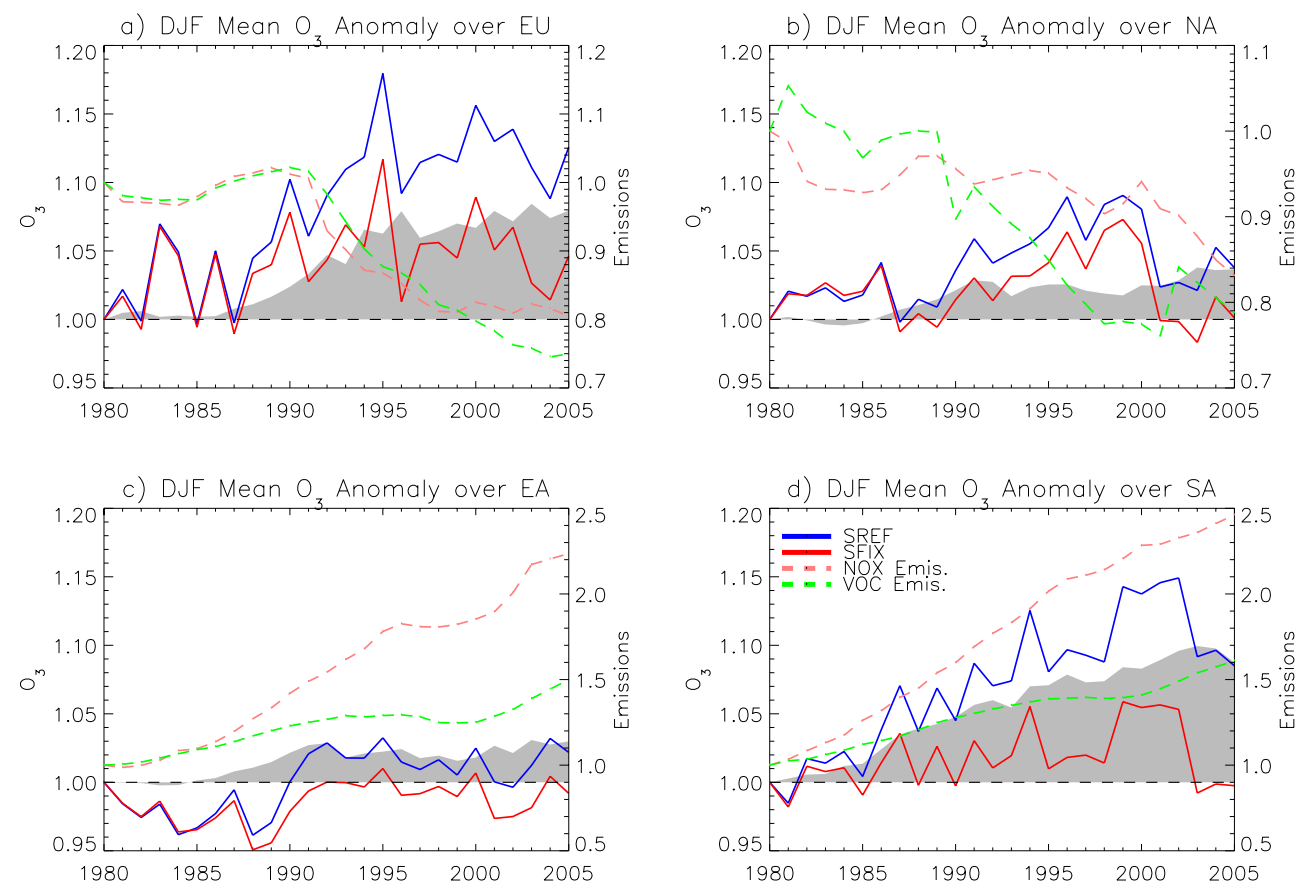

Fig. 7. Winter (DJF) anomalies of surface $\mathrm{O}_{3}$ concentrations averaged over the selected regions (shown in Fig. 1). On the left $y$-axis anomalies of $\mathrm{O}_{3}$ surface concentrations for the period 1980-2005 are expressed as the ratios between seasonal means for each year and the year 1980. The blue line represents the SREF simulation (changing meteorology and changing anthropogenic emissions), the red line the SFIX simulation (changing meteorology and fixed anthropogenic emissions at the level of 1980), while the gray area indicates the SREFSFIX difference. On the right y-axis the green and pink dashed lines represent the changes, i.e. the ratio between each year and 1980, of total annual VOC and $\mathrm{NO}_{\mathrm{x}}$ emissions, respectively.
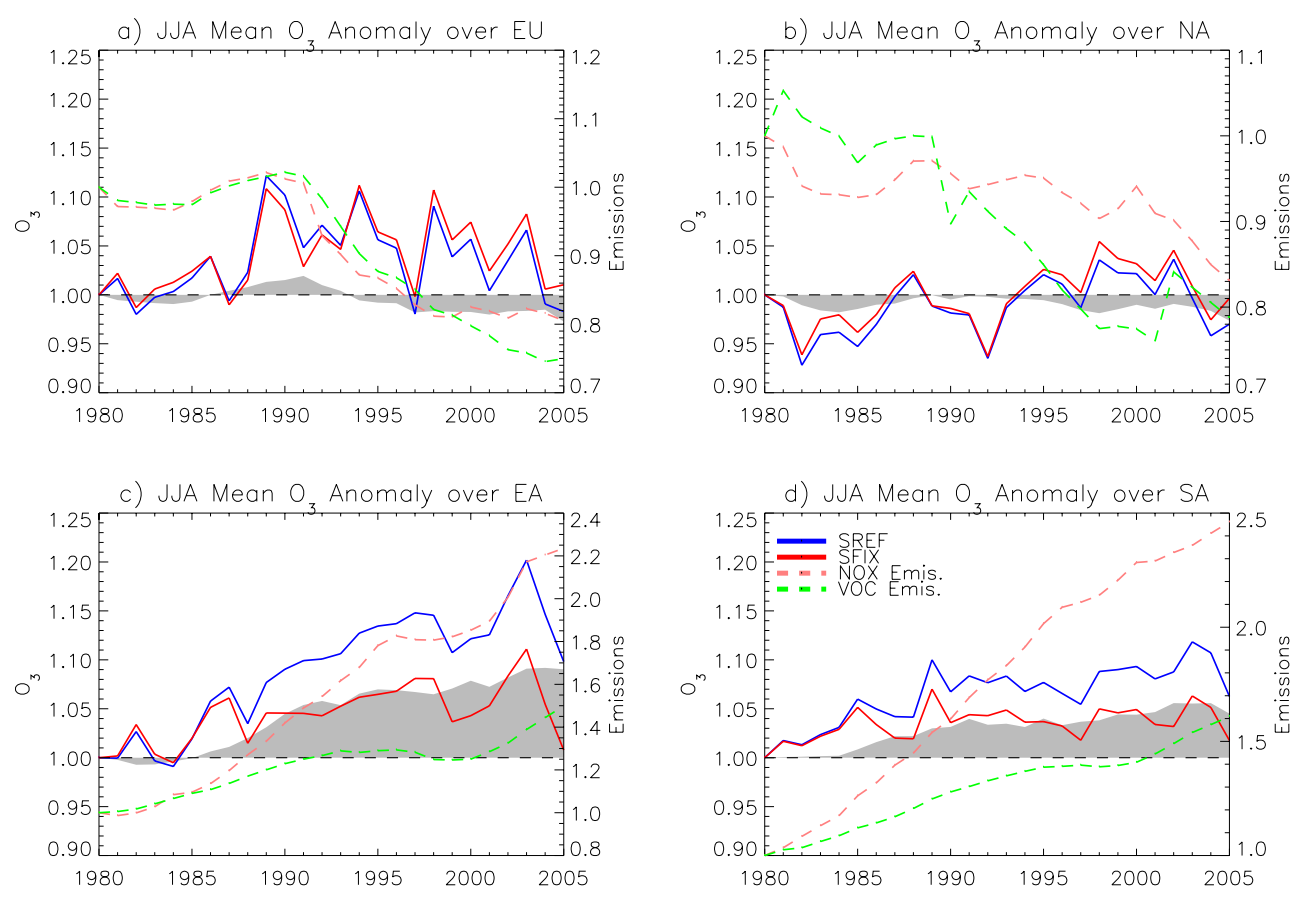

Fig. 8. As Fig. 7 for summer (JJA) anomalies of surface $\mathrm{O}_{3}$ concentrations. 
caused upward trends in Northern and Central Europe, and downward trends in Southern Europe.

The regional responses of surface ozone can be compared to the HTAP multi-model emission perturbation study of Fiore et al. (2009), which considered identical regions and is thus directly comparable to this study. They found that the $20 \%$ reduction over EU of all HTAP emissions determined an increase of $\mathrm{O}_{3}$ by $0.2 \mathrm{ppbv}$ in winter, and an $\mathrm{O}_{3}$ decrease by $-1.7 \mathrm{ppbv}$ in summer (average of 21 models), to a large extent driven by $\mathrm{NO}_{\mathrm{x}}$ emissions. Considering similar annual mean reductions in $\mathrm{NO}_{\mathrm{x}}$ and $\mathrm{VOC}$ emissions over $\mathrm{Eu}-$ rope from 1980-2005, we found a stronger emission driven increase of up to $3 \mathrm{ppbv}$ in winter, and a decrease of up to 1 ppbv in summer. An important difference between the two studies may be the use of a spatially homogeneous emission reduction in HTAP, while the emissions used here generally included larger emission reductions in Northern Europe while emissions in Mediterranean countries remained more or less constant.

The calculated and observed $\mathrm{O}_{3}$ trends for the period 1990-2005 are relatively small compared to the inter-annual variability. In winter (DJF) (Fig. 6) measured trends confirm increasing ozone in most parts of Europe. The observed trends are substantially larger $\left(0.3-0.5 \mathrm{ppbv} \mathrm{yr}^{-1}\right)$ than the model results $\left(0-0.2 \mathrm{ppbv} \mathrm{yr}^{-1}\right)$, except in Western Europe (WEU). In summer (JJA) the agreement of calculated and observed trends is small: in the observations they are close to zero for all European regions with large $95 \%$ confidence intervals, while calculated trends show significant decreases $\left(0.1-0.45 \mathrm{ppbv} \mathrm{yr}^{-1}\right)$ of $\mathrm{O}_{3}$. Despite seasonal $\mathrm{O}_{3}$ trends not being well captured by the model, the seasonally averaged modeled and measured surface ozone concentrations are reasonably well correlated for a large number of stations (Appendix B). In winter the simulated inter-annual variability seemed to be somewhat underestimated, pointing to missing variability coming from e.g. stratosphere-troposphere or long-range transport. In summer the correlations are generally increasing for Central Europe and decreasing for Western Europe.

Our results are generally in good agreement with previous estimates of observed $\mathrm{O}_{3}$ trends, e.g. Jonson et al. (2006); Lamarque et al. (2010); Cui et al. (2011); Wilson et al. (2011). In those studies they reported observed annual $\mathrm{O}_{3}$ trends of $0.32-0.40 \mathrm{ppbv} \mathrm{yr}^{-1}$ for stations in central Europe, which are comparable with the observed trends calculated in our study (Fig. B3 in Appendix B). In Mace Head Lamarque (2010) reported an increasing trend of $0.18 \mathrm{ppbv} \mathrm{yr}^{-1}$, comparable to our study (Fig. B3 in Appendix B). Jonson et al. (2006) reported seasonal trends of $\mathrm{O}_{3}$ ranging between 0.13 and $0.5 \mathrm{ppbv} \mathrm{yr}^{-1}$ in winter (JF) and between -0.59 and -0.12 ppbv yr $^{-1}$ in summer (JJA). Wilson et al. (2011) calculated positive annual $\mathrm{O}_{3}$ trends in Central and NorthWestern Europe (0.14-0.41 $\mathrm{pbbv} \mathrm{yr}^{-1}$ ), and significant negative annual trends at $11 \%$ of sites mainly located in Eastern and South-Western Europe $\left(-1.28--0.24 \mathrm{pbbv} \mathrm{yr}^{-1}\right)$.

\subsubsection{North America}

Computed annual mean surface $\mathrm{O}_{3}$ over North America (Fig. 5i) for 1981-1985 was 48.3 ppbv. Higher $\mathrm{O}_{3}$ concentrations are found over California and in the continental outflow regions, Atlantic and Pacific Oceans, and the Gulf of Mexico, and lower concentrations north of $45^{\circ} \mathrm{N}$. Anthropogenic $\mathrm{NO}_{\mathrm{x}}$ in NA decreased by $17 \%$ between 1980 and 2005, particularly in the 1990s (-22\%) (Fig. 2b). These emission reductions produced an annual mean $\mathrm{O}_{3}$ concentration decrease up to $1 \mathrm{ppbv}$ over all the Eastern US, $1-2$ ppbv over the Southern US, and $1 \mathrm{ppbv}$ in the Western US. Changes in anthropogenic emissions from 1980 to 2005 (Fig. 5j) resulted in a small average increase of ozone by $0.28 \mathrm{ppbv}$ over NA, where effects on $\mathrm{O}_{3}$ of emission reductions in the US and Canada were balanced by higher $\mathrm{O}_{3}$ concentrations mainly over the tropics (below $25^{\circ} \mathrm{N}$ ). Changes in meteorology and natural emissions (Fig. 5k) increased $\mathrm{O}_{3}$ between 1 and 5 ppbv over the continent, and reduced $\mathrm{O}_{3}$ by up to 5 ppbv over Western Mexico and the Atlantic Ocean (average of $0.89 \mathrm{ppbv}$ over the entire region). Thus natural variability was the largest driver of the over-all average regional increase of $1.58 \mathrm{ppbv}$ in SREF (Fig. 51). Over NA natural variability is the main driver of summer (JJA) $\mathrm{O}_{3}$ fluctuations from $-7 \%$ to $5 \%$ (Fig. 8 b). In winter (Fig. $7 \mathrm{~b}$ ), the contribution of emissions and chemistry is strongly influencing these relative changes. Computed and measured summer concentrations were better correlated than those in winter (Appendix B). However, while in winter, an analysis of the observed trends seems to suggest $0-0.2 \mathrm{ppbv} \mathrm{yr}^{-1}$ $\mathrm{O}_{3}$ increases, the model predicts small $\mathrm{O}_{3}$ decreases instead, though these differences are not often significant (see also Appendix B). In summer modeled upward trends (SREF) are not confirmed by measurements, except for the Western US (WUS). These computed upward trends were strongly determined by the large-scale meteorological variability (SFIX), and the model trends solely based on anthropogenic emission changes (SREF-SFIX) would be more consistent with observations.

Despite the difficulty in comparing trends calculated with different methods and for different periods, our observed trends are qualitatively in good agreement with previous studies over the Western US: Oltmans et al. (2008) observed positive trends at some sites, but no significant changes at others; Jaffe and Ray (2007) estimated positive $\mathrm{O}_{3}$ trends of $0.21-0.62 \mathrm{ppbv} \mathrm{yr}^{-1}$ in winter and $0.43-0.50 \mathrm{ppbv} \mathrm{yr}^{-1}$ in summer; Parrish et al. (2009) found $0.43 \pm 0.17 \mathrm{ppbv} \mathrm{yr}^{-1}$ in winter and $0.24 \pm 0.16 \mathrm{ppbv} \mathrm{yr}^{-1}$ in summer $\mathrm{O}_{3}$ trends; Lamarque et al. (2010) found annual increasing $\mathrm{O}_{3}$ trend of $0.33 \mathrm{ppbv} \mathrm{yr}^{-1}$; Chan and Vet (2010) found larger positive daytime $\mathrm{O}_{3}$ summer and winter trends, close to $1 \mathrm{ppbv} \mathrm{yr}^{-1}$, for the period 1997-2006. Over the Eastern US our study qualitatively agrees with Chan and Vet (2010) who found decreasing significant trends over all the Eastern US in summer, and mainly no significant trends in winter. 


\subsubsection{East Asia}

In East Asia, we calculated an annual mean surface $\mathrm{O}_{3}$ concentration of $43.6 \mathrm{ppbv}$ for 1981-1985. Surface $\mathrm{O}_{3}$ is less than $30 \mathrm{ppbv}$ over North-Eastern China, and influenced by continental outflow conditions, up to $50 \mathrm{ppbv}$ concentrations are computed over the Northern Pacific Ocean and Japan (Fig. 5m). Over EA, anthropogenic $\mathrm{NO}_{\mathrm{x}}$ and VOC emissions increased by $125 \%$ and $50 \%$, respectively, from 1980 to 2005. Between 1981-1985 and 2001-2005 $\mathrm{O}_{3}$ is reduced by $10 \mathrm{ppbv}$ in North Eastern China, due to reaction with freshly emitted NO. In contrast, $\mathrm{O}_{3}$ concentrations increase close to the coast of China by up to $10 \mathrm{ppbv}$, and up to $5 \mathrm{ppbv}$ over the entire north Pacific, reaching North America (Fig. 5b). For the entire EA region (Fig. 5n) we found an increase of annual mean $\mathrm{O}_{3}$ concentrations of $2.43 \mathrm{ppbv}$. The effect of meteorology and natural emissions is generally significantly positive, with an EA-wide increase of $1.6 \mathrm{ppbv}$, and up to $5 \mathrm{ppbv}$ in northern and southern continental EA (Fig. 5o). The combined effect of anthropogenic emissions and meteorology is an increase of $4.13 \mathrm{ppbv}$ in $\mathrm{O}_{3}$ concentrations (Fig. 5p). During this period, the seasonal mean $\mathrm{O}_{3}$ concentrations were increasing by $3 \%$ and $9 \%$ in winter and summer, respectively (Figs. 7c and 8c). The effect of natural variability on the seasonal mean $\mathrm{O}_{3}$ concentrations shows opposite effects in winter and summer: a reduction between 0 and $5 \%$ in winter, and an increase between 0 and $10 \%$ in summer. The 3 long-term measurement datasets at our disposal (not shown) indicate large inter-annual variability of $\mathrm{O}_{3}$ and no significant trend in the time period from 1990 to 2005, therefore they are not plotted in Fig. 6.

\subsubsection{South Asia}

Of all 4 regions, the largest relative change in anthropogenic emissions occurred over SA: $\mathrm{NO}_{\mathrm{x}}$ emissions increased by $150 \%$, VOC by $60 \%$, and sulfur by $220 \%$. South Asian $\mathrm{O}_{3}$ inter-annual variability is rather different from EA, NA, and EU, because the SA region is almost completely situated in the tropics. Meteorology is highly influenced by the Asian monsoon circulation, with the wet season in JuneAugust. We calculate an annual mean surface $\mathrm{O}_{3}$ concentration of $48.2 \mathrm{ppbv}$, with values between 45 and $60 \mathrm{ppbv}$ over the continent (Fig. 5q). Note that the high concentrations at the northern edge of the region may be influenced by the orography of the Himalaya. The increasing anthropogenic emissions enhanced annual mean surface $\mathrm{O}_{3}$ concentrations by on average $4.24 \mathrm{ppbv}$ (Fig. $5 \mathrm{r}$ ), and more than 5 ppbv over India and the Gulf of Bengal. In the $\mathrm{NH}$ winter (dry season) the increase in $\mathrm{O}_{3}$ concentrations of up to $10 \%$ due to anthropogenic emissions is more pronounced than in the summer (wet season), with an increase of only $5 \%$ in JJA (Figs. $7 \mathrm{~d}$ and $8 \mathrm{~d}$ ). The effect of meteorology produced an annual mean $\mathrm{O}_{3}$ increase of $1.15 \mathrm{ppbv}$ over the region and more than 2 ppbv in the Ganges valley and in the southern Gulf of
Bengal (Fig. 5s). The total variability in seasonal mean $\mathrm{O}_{3}$ concentrations is on the order of $5 \%$, both in winter and summer (Figs. $7 \mathrm{~d}$ and $8 \mathrm{~d}$ ). In $25 \mathrm{yr}$, the computed annual mean $\mathrm{O}_{3}$ concentrations increased by 5.12 ppbv over SA, approximately $75 \%$ of which are related to increasing anthropogenic emissions (Fig. 5t). Unfortunately, to our knowledge no such long-term data of sufficient quality exist in India.

\subsection{Variability of the global ozone budget}

We will now discuss the changes in global tropospheric $\mathrm{O}_{3}$. To put our model results in a multi-model context, we show in Fig. 9 the global tropospheric $\mathrm{O}_{3}$ budget along with budget terms derived from Stevenson et al. (2006). $\mathrm{O}_{3}$ budget terms were calculated using an assumed chemical tropopause, with a threshold of $150 \mathrm{ppbv}$ of $\mathrm{O}_{3}$. The annual globally integrated chemical production $(P)$, loss $(L)$, surface deposition $(D)$, and stratospheric influx $\left(S_{\text {inf }}=L+D-P\right)$ terms are well in the range of those reported by Stevenson et al. (2006), though $\mathrm{O}_{3}$ burden and lifetime are at the high end. In our study, the variability in production and loss are clearly determined by meteorological variability, with the 1997-1998 ENSO event standing out. The increasing turnover of tropospheric ozone manifests in gradually decreasing ozone lifetimes ( -1 day from 1980 to 2005), while total tropospheric ozone burden increases from 370 to $380 \mathrm{Tg}$, caused by increasing production and stratospheric influx.

Further, we compare our work to a re-analysis study by Hess and Mahowald (2009), which focused on the relationship between meteorological variability and ozone. Hess and Mahowald (2009) used the chemical transport model (CTM) MOZART2 to conduct two ozone simulations from 1979 to 1999 without considering the inter-annual changes in emissions (except for lightning emissions) and is thus very comparable to our SFIX simulation. The simulations were driven by two different re-analysis methodologies: the National Center for Environmental Prediction/National Center for Atmospheric Research (NCEP/NCAR) re-analysis; the output of the Community Atmosphere Model (CAM3, Collins et al., 2006), driven by observed sea surface temperatures (SNCEP and SCAM in Hess and Mahowald (2009), respectively). The comparison of our model (in particular the SFIX simulation) driven by the ECMWF ERA-40 re-analysis with Hess and Mahowald (2009) provides insight in the extent to which these different approaches impact the inter-annual variability of ozone. In Table 3 we compare the results of SFIX with the two Hess and Mahowald (2009) model results. We excluded the last $5 \mathrm{yr}$ of our SFIX simulation in order to allow direct statistical comparison with the period 1980-2000.

\subsubsection{Hydrological cycle and lightning}

The variability of photolysis frequencies of $\mathrm{NO}_{2}\left(J_{\mathrm{NO}_{2}}\right)$ at the surface is an indicator for overhead cloud cover fluctuations, with lower values corresponding to larger cloud cover. 
Table 3. Average, standard deviation (SD) and relative standard deviation (RSD, standard deviation divided by the mean) of globally averaged variables in this work, SCAM and SNCEP(Hess and Mahowald, 2009) (1980-2000). Three dimensional variables are density weighted and averaged between the surface and $280 \mathrm{hPa}$. Three dimensional quantities evaluated at the surface are prefixed with Sfc. The standard deviation is calculated as the standard deviation of the monthly anomalies (the monthly value minus the mean of all years for that month).

\begin{tabular}{|c|c|c|c|c|c|c|c|c|c|}
\hline & \multicolumn{3}{|c|}{ ERA-40 (this work SFIX) } & \multicolumn{3}{|c|}{ SCAM (Hess, 2009) } & \multicolumn{3}{|c|}{ SNCEP (Hess, 2009) } \\
\hline & Average & $\mathrm{SD}$ & RSD & Average & SD & RSD & Average & SD & RSD \\
\hline Sfc $T(\mathrm{~K})$ & 287 & 0.112 & 0.000391 & 287 & 0.116 & 0.000403 & 287 & 0.121 & 0.00042 \\
\hline Sfc $J \mathrm{NO}_{2}\left(\mathrm{~s}^{-1} \times 10^{-3}\right)$ & 2.13 & 0.0121 & 0.00567 & 2.43 & 0.00454 & 0.00187 & 2.39 & 0.00814 & 0.00341 \\
\hline LNO $\left(\operatorname{TgN~yr}^{-1}\right)$ & 3.91 & 0.153 & 0.0387 & 4.71 & 0.118 & 0.0251 & 2.79 & 0.211 & 0.0759 \\
\hline PRECT (mm day ${ }^{-1}$ ) & 2.95 & 0.0331 & 0.011 & 2.42 & 0.0145 & 0.006 & 2.4 & 0.0389 & 0.0162 \\
\hline$Q\left(\mathrm{~g} \mathrm{~kg}^{-1}\right)$ & 4.72 & 0.060 & 0.0127 & 3.46 & 0.0411 & 0.0119 & 3.38 & 0.0361 & 0.0107 \\
\hline $\mathrm{O}_{3}(\mathrm{ppbv})$ & 47.79 & 0.819 & 0.01714 & 46 & 0.192 & 0.00418 & 48.4 & 0.752 & 0.0155 \\
\hline $\mathrm{Sfc} \mathrm{O}_{3}(\mathrm{ppbv})$ & 36.1 & 0.595 & 0.0165 & 29.8 & 0.122 & 0.0041 & 31.2 & 0.468 & 0.015 \\
\hline $\mathrm{CO}$ (ppbv) & 0.100 & 0.000450 & 0.04482 & 0.083 & 0.000449 & 0.00542 & 0.0847 & 0.000388 & 0.00458 \\
\hline $\mathrm{OH}\left(\right.$ mole mole $\left.{ }^{-1} \times 10^{15}\right)$ & 63.1 & 1.269 & 0.02012 & 73.5 & 0.707 & 0.00962 & 70.4 & 0.847 & 0.012 \\
\hline $\mathrm{HNO}_{3}$ (pptv) & 127 & 13.95 & 0.1096 & 121 & 1.22 & 0.0101 & 121 & 1.49 & 0.0123 \\
\hline
\end{tabular}
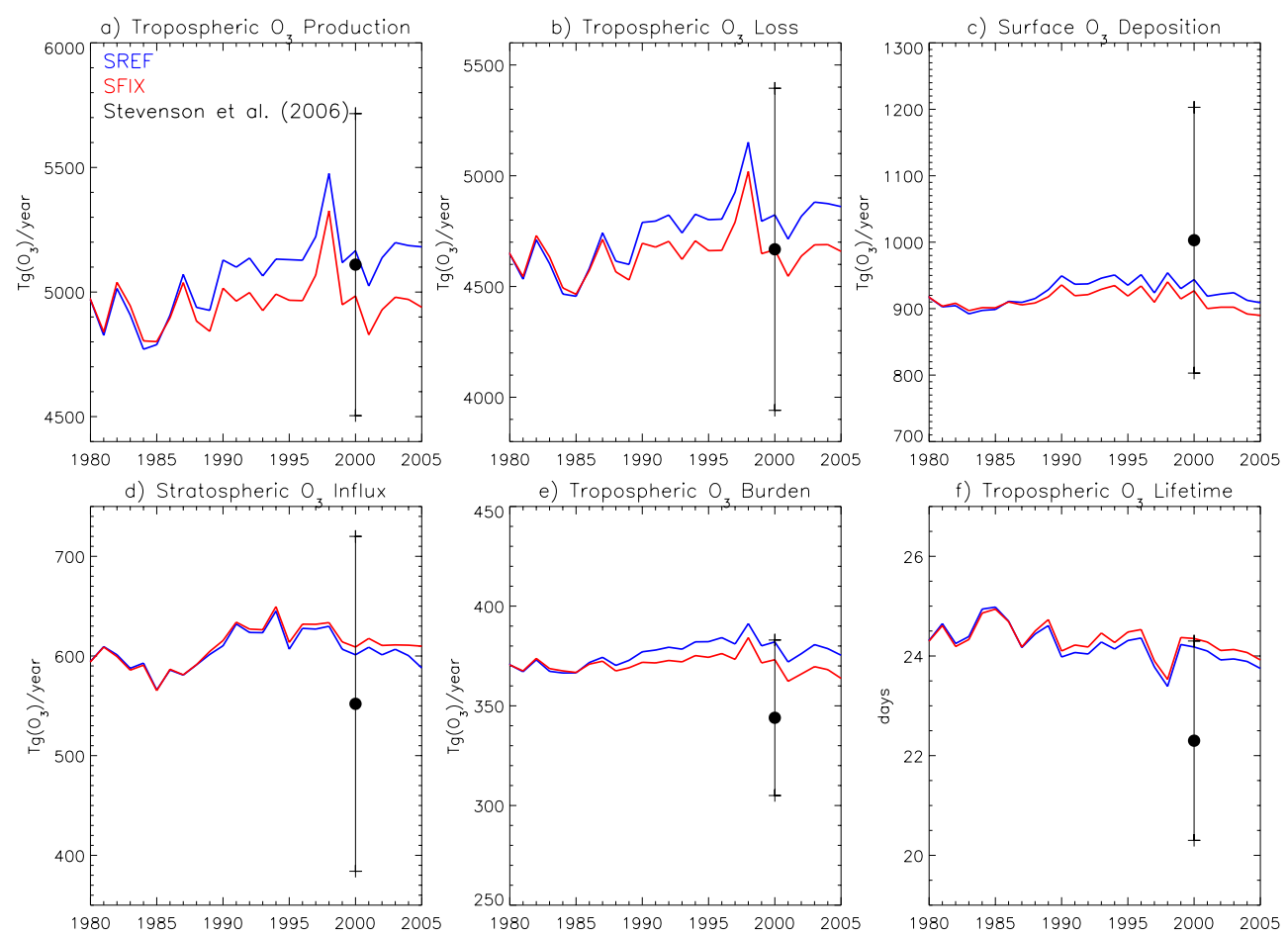

Fig. 9. Global tropospheric $\mathrm{O}_{3}$ budget calculated for the period 1980-2005 for the SREF (blue) and SFIX (red) ECHAM5-HAMMOZ simulations: (a) chemical production $(P)$; (b) chemical loss $(L)$; (c) surface deposition $(D)$; (d) stratospheric influx $\left(S_{\text {inf }}=L+D-P\right)$; (e) tropospheric burden $\left(B_{\mathrm{O}_{3}}\right)$; (f) lifetime $\left(\tau_{\mathrm{O}_{3}}=B_{\mathrm{O}_{3}} /(L+D)\right)$. The black points for the year 2000 represent the mean \pm standard deviation budgets as found in the multi model study of Stevenson et al. (2006).

$J_{\mathrm{NO}_{2}}$ values are ca. $10 \%$ lower in our SFIX (ECHAM5) simulation compared to the two simulations reported by Hess and Mahowald (2009). This may be due to a different representation of the cloud impact on photolysis frequencies (in presence of a cloud layer lower rates at surface and higher rates above) as calculated in our model using Fast-J.2 (see
Appendix A) compared to the look-up-tables used by Hess and Mahowald (2009). Furthermore, we found $22 \%$ higher average precipitation and $37 \%$ higher tropospheric water vapor in ECHAM5, than reported for the NCEP and CAM re-analyses, respectively. As discussed by Hagemann et al. (2006), ECHAM5 humidity may be biased high regarding 
processes involving the hydrological cycle, especially in the $\mathrm{NH}$ summer in the tropics. The computed production of $\mathrm{NO}_{\mathrm{x}}$ from lightning (LNO) of $3.91 \mathrm{Tg} \mathrm{yr}^{-1}$ in our SFIX simulation resides between the values found in the NCEP- and CAM-driven simulations of Hess and Mahowald (2009), despite the large uncertainties of lightning parameterizations (see Sect. 3.2).

\subsubsection{Variability, re-analysis and nudging methods}

The global multi annual averages of the meteorological variables and gas concentrations at the surface and in the troposphere are rather similar in the 3 simulations (Table 3 ). $\mathrm{O}_{3}$ is ranging from 46 to $48.4 \mathrm{ppbv}$, while $20 \%$ higher values are found for surface $\mathrm{O}_{3}$ in our SFIX simulation. Our global tropospheric average of $\mathrm{CO}$ concentrations is $15 \%$ higher than in Hess and Mahowald (2009), probably due to different biogenic CO and VOCs emissions. Despite larger amounts of water vapor, and lower surface $J_{\mathrm{NO}_{2}}$ in SFIX, our calculated $\mathrm{OH}$ tropospheric concentrations are smaller by $15 \%$. Remarkable differences compared to Hess and Mahowald (2009) are found in the inter-annual variability. In general the variability calculated in our SFIX simulation is closer to the SNCEP simulation of Hess and Mahowald (2009), but our model exhibits a larger inter-annual variability of global $\mathrm{O}_{3}, \mathrm{CO}, \mathrm{OH}$, and $\mathrm{HNO}_{3}$ than the CAM-driven simulation analysis by Hess and Mahowald (2009). This likely indicates that nudging with different re-analysis datasets (such as ECMWF and NCEP), or only prescribing monthly averaged sea-surface temperatures, can give significantly different answers on the processes that govern inter-annual variations in the chemical composition of the troposphere. The variability of $\mathrm{OH}$ (calculated as the relative standard deviation, RSD) in our SFIX simulation is higher by a factor of 2 than those in SCAM and SNCEP, and CO, $\mathrm{HNO}_{3}$ up to a factor of 10 . We speculate that these differences point to differences in the hydrological cycle among the models, which influence $\mathrm{OH}$ through changes in cloud cover and $\mathrm{HNO}_{3}$ through different washout rates. A similar conclusion was reached by Auvray et al. (2007), who analyzed ozone formation and loss rates from the ECHAM5-MOZ and GEOS-CHEM models for different pollution conditions over the Atlantic Ocean. Since the methodology used in our SFIX simulation should be rather comparable to that used for the NCEP-driven MOZART2 simulation, we speculate that in addition to the differences in re-analysis (NCEP/NCAR and ECMWF/ERA-40), also different nudging methodologies may strongly impact the calculated inter-annual variabilities.

\subsection{OH variability}

The main processes that contribute to the $\mathrm{OH}$ variability are both meteorological and chemical. Dentener et al. (2003) found that OH variability for the period 1979-1993 was mainly driven by meteorological processes, i.e. humid- ity/temperature and wet removal/precipitations. They found only a small total contribution from the changes in chemical species like $\mathrm{CH}_{4}, \mathrm{O}_{3}$, and emissions of $\mathrm{NO}_{\mathrm{x}}$, VOCs, and CO. Differently from Dentener et al. (2003), in our study the effects of natural processes (in the SFIX simulation) includes also changes in emissions of $\mathrm{CO}, \mathrm{NO}_{\mathrm{x}}$, and VOCs from biomass burning and lightning emissions. Furthermore, the variability from stratospheric $\mathrm{O}_{3}$ is not included, as well as the effect of Mt. Pinatubo eruption. To estimate the changes in the global oxidation capacity, we calculated the global mean tropospheric $\mathrm{OH}$ concentration weighted by the reaction coefficient of $\mathrm{CH}_{4}$, following Lawrence et al. (2001). We found a mean value of $1.2 \pm 0.016 \times 10^{6}$ molecules $\mathrm{cm}^{-3}$ in the SREF simulation (Table 2, within the $1.06-1.39 \times 10^{6}$ molecules $\mathrm{cm}^{-3}$ range calculated by Lawrence et al., 2001). The mean value of the yearly means of $\mathrm{CH}_{4}$ lifetime over the period 1980-2005 is $10.4 \pm 0.14 \mathrm{yr}$ in the SREF simulation. This value is just above the 1- $\sigma$ interval of $\mathrm{CH}_{4}$ lifetimes reported by the all model average in Stevenson et al. (2006). In Fig. 4d we show the global tropospheric average monthly mean anomalies of OH. During the period 1980-2005 we found a decreasing $\mathrm{OH}$ trend of $-0.33 \times 10^{4}$ molecules $\mathrm{cm}^{-3}\left(R^{2}=\right.$ 0.79 due to natural variability), balanced by an opposite trend of $0.30 \times 10^{4}$ molecules $\mathrm{cm}^{-3}\left(R^{2}=0.95\right)$ due to anthropogenic emission changes. In agreement with an earlier study by Fiore et al. (2006) we found a strong relationship between global lightning and $\mathrm{OH}$ inter-annual variability with a correlation of 0.78 . This correlation drops to 0.32 for SREF, which additionally includes the effect of changing anthropogenic $\mathrm{CO}$, VOC and $\mathrm{NO}_{\mathrm{x}}$ emissions. Lower correlations were found with water vapor $(R=-0.48)$ and photolysis rates at surface (e.g. $J_{\mathrm{NO}_{2}}, R=-0.65 ; J_{\mathrm{O}_{1} \mathrm{D}}, R=-0.56$ ). The resulting $\mathrm{OH}$ inter-annual variability of $2 \%$ for the impact of meteorology (SFIX) was close to the estimate of Hess and Mahowald (2009) (for the period 1980-2000, Table 3), and much smaller than the $10 \%$ variability estimated by Prinn et al. (2005), but somewhat larger than the global inter-annual variability of $1.5 \%$ analyzed by Dentener et al. (2003). The latter authors however did not include interannual varying biomass burning emissions. Dentener et al. (2003) computed an increasing trend of $0.24 \pm 0.06 \% \mathrm{yr}^{-1}$ in OH global mean concentrations for the period 19791993 using a different model, which was mainly caused by meteorological variability. For a slightly shorter period (1980-1993), we found a decreasing trend of $-0.27 \% \mathrm{yr}^{-1}$ in our SFIX run. Montzka et al. (2011) estimate an interannual variability of $\mathrm{OH}$ in the order of $2 \pm 1.8 \%$ for the period 1985-2008, which compares reasonably well with our results of $1.6 \%$ and $2.4 \%$ for the SREF and SFIX runs (1980-2005, Table 2), respectively. The calculated OH decline from 2001 to 2005, which was not strongly correlated to global surface temperature, humidity or lightning, could have implications for the understanding of the stagnation of atmospheric methane growth during the first part of 2000s. 
However, we do not want to over-interpret this decline, since in this period we used meteorological data from the operational ECMWF analysis instead of ERA-40 (Sect. 2). On the other hand we have no evidence of other discontinuities in our analysis, and the magnitude of the $\mathrm{OH}$ changes was similar to earlier changes in the period 1980-1995.

\section{Surface and column $\mathrm{SO}_{4}^{2-}$}

In this section we analyze global and regional sulfate surface concentrations (Sect. 5.1) and the global sulfate budget (Sect. 5.2) including their variability. The regional analysis and comparison with measurements follows the approach of the ozone analysis above.

\subsection{Global and regional surface sulfate}

Global average surface $\mathrm{SO}_{4}^{2-}$ concentrations are 1.12 and $1.18 \mu \mathrm{g}(\mathrm{S}) \mathrm{m}^{-3}$ for the SREF and SFIX runs, respectively (Table 2). Anthropogenic emission changes induce a decrease of ca. $0.1 \mu \mathrm{g}(\mathrm{S}) \mathrm{m}^{-3} \mathrm{SO}_{4}^{2-}$ between 1980 and $2005 \mathrm{in}$ SREF (Fig. 4e). Monthly anomalies of $\mathrm{SO}_{4}^{2-}$ surface concentrations range from -0.1 , to $0.2 \mu \mathrm{g}(\mathrm{S}) \mathrm{m}^{-3}$. The 12-month running averages of monthly anomalies are in the range of $\pm 0.1 \mu \mathrm{g}(\mathrm{S}) \mathrm{m}^{-3}$ for SREF, and about half of this in the SFIX simulation. The anomalies in global average $\mathrm{SO}_{4}^{2-}$ surface concentrations do not show a significant correlation with meteorological variables on the global scale.

\subsubsection{Europe}

For 1981-1985 we compute an annual average $\mathrm{SO}_{4}^{2-}$ surface concentration of $2.57 \mu \mathrm{g}(\mathrm{S}) \mathrm{m}^{-3}$ (Fig. 10e), with the largest values over the Mediterranean and Eastern Europe. Emission controls (Fig. 2a) reduced $\mathrm{SO}_{4}^{2-}$ surface concentrations (Figs. 10f, 11a, and 12a) by almost 50\% in 2001-2005. Figures $10 \mathrm{f}$ and $\mathrm{g}$ show that emission reductions and meteorological variability contribute ca. $85 \%$ and $15 \%$ respectively, to the overall differences between 2001-2005 and 19811985, indicating a small but significant role for meteorological variability in the $\mathrm{SO}_{4}^{2-}$ signal. Figure $10 \mathrm{~h}$ shows that the largest $\mathrm{SO}_{4}^{2-}$ decreases occurred in Southern and NorthEastern Europe. In Figs. 11a and 12a we display seasonal differences in the $\mathrm{SO}_{4}^{2-}$ response to emissions and meteorological changes. SFIX European winter (DJF) surface sulfate varies $\pm 30 \%$ compared to 1980 , while in summer (JJA) concentrations are between 0 and $20 \%$ larger than in 1980. The decline of European surface sulfur concentrations in SREF is larger in winter $(50 \%)$ than in summer $(37 \%)$.

Measurements mostly confirm these model findings. Indeed, inter-annual seasonal anomalies of $\mathrm{SO}_{4}^{2-}$ in winter (Appendix B) generally correlate well $(R>0.5)$ at most stations in Europe. In summer, the modeled inter-annual variability is always underestimated (normalized standard devi- ation of $0.3-0.9$ ), most likely indicating an underestimate in the variability of precipitation scavenging in the model over Europe. Modeled and measured $\mathrm{SO}_{4}^{2-}$ trends are in good agreement in most European regions (Fig. 6). In winter the observed declines of $0.02-0.07 \mu \mathrm{g}(\mathrm{S}) \mathrm{m}^{-3} \mathrm{yr}^{-1}$ are underestimated in NEU and EEU, and overestimated in the other regions. In summer the observed declines of $0.02-$ $0.08 \mu \mathrm{g}(\mathrm{S}) \mathrm{m}^{-3} \mathrm{yr}^{-1}$ are overestimated in SEU, and underestimated in CEU, WEU, and EEU.

\subsubsection{North America}

The calculated annual mean surface concentration of sulfate over the NA region for the period 1981-1985 is $0.65 \mu \mathrm{g}(\mathrm{S}) \mathrm{m}^{-3}$. Highest concentrations are found over the Eastern and Southern US (Fig. 10i). NA emissions reductions of $35 \%$ (Fig. 2b) reduced $\mathrm{SO}_{4}^{2-}$ concentrations on average by $0.18 \mu \mathrm{g}(\mathrm{S}) \mathrm{m}^{-3}$ ), and up to $1 \mu \mathrm{g}(\mathrm{S}) \mathrm{m}^{-3}$ over the Eastern US (Fig. 10j). Meteorological variability results in a small overall increase of $0.05 \mu \mathrm{g}(\mathrm{S}) \mathrm{m}^{-3}$ (Fig. 10k). Changes in emissions and meteorology can almost be combined linearly (Fig. 101). The total decline is thus $0.11 \mu \mathrm{g}(\mathrm{S}) \mathrm{m}^{-3}$ : $-20 \%$ in winter and $-25 \%$ in summer between 1980-2005, indicating a fairly low seasonal dependency.

Like in Europe, also in North America measured interannual seasonal variability is smaller than in our calculations in winter and larger in summer (Appendix B). Observed winter downward trends are in the range of $0-0.03 \mu \mathrm{g}(\mathrm{S}) \mathrm{m}^{-3} \mathrm{yr}^{-1}$ in reasonable agreement with the range of $0.01-0.06 \mu \mathrm{g}(\mathrm{S}) \mathrm{m}^{-3} \mathrm{yr}^{-1}$ calculated in the SREF simulation. In summer, except for the Western US (WUS), observed $\mathrm{SO}_{4}^{2-}$ trends range between -0.08 and $-0.05 \mu \mathrm{g}(\mathrm{S}) \mathrm{m}^{-3} \mathrm{yr}^{-1}$, and the calculated trends decline only between $0.03-0.04 \mu \mathrm{g}(\mathrm{S}) \mathrm{m}^{-3} \mathrm{yr}^{-1}$ ) (Fig. 6). We suspect that a poor representation of the seasonality of anthropogenic sulfur emissions contributes to both the winter overestimate and the summer underestimate of the $\mathrm{SO}_{4}^{2-}$ trends.

\subsubsection{East Asia}

Annual mean $\mathrm{SO}_{4}^{2-}$ during $1981-1985$ was $0.9 \mu \mathrm{g}(\mathrm{S}) \mathrm{m}^{-3}$ with higher concentrations over Eastern China, Korea, and in the continental outflow over the Yellow Sea (Fig. 10m). Growing anthropogenic sulfur emissions (60\% over EA) produced an increase in regional annual mean $\mathrm{SO}_{4}^{2-}$ concentrations of $0.24 \mu \mathrm{g}(\mathrm{S}) \mathrm{m}^{-3}$ in the $2001-2005$ period. Largest increases (practically a doubling of concentrations) were found over Eastern China and Korea (Fig. 10n). The contribution of changing meteorology and natural emissions is relatively small $\left(0.01 \mu \mathrm{g}(\mathrm{S}) \mathrm{m}^{-3}\right.$ or $15 \%$, Fig. $\left.10 \mathrm{o}\right)$, and the coupled effect of changing emissions and meteorology is dominated by the emissions perturbation $\left(0.19 \mu \mathrm{g}(\mathrm{S}) \mathrm{m}^{-3}\right.$, Fig. 10p). 

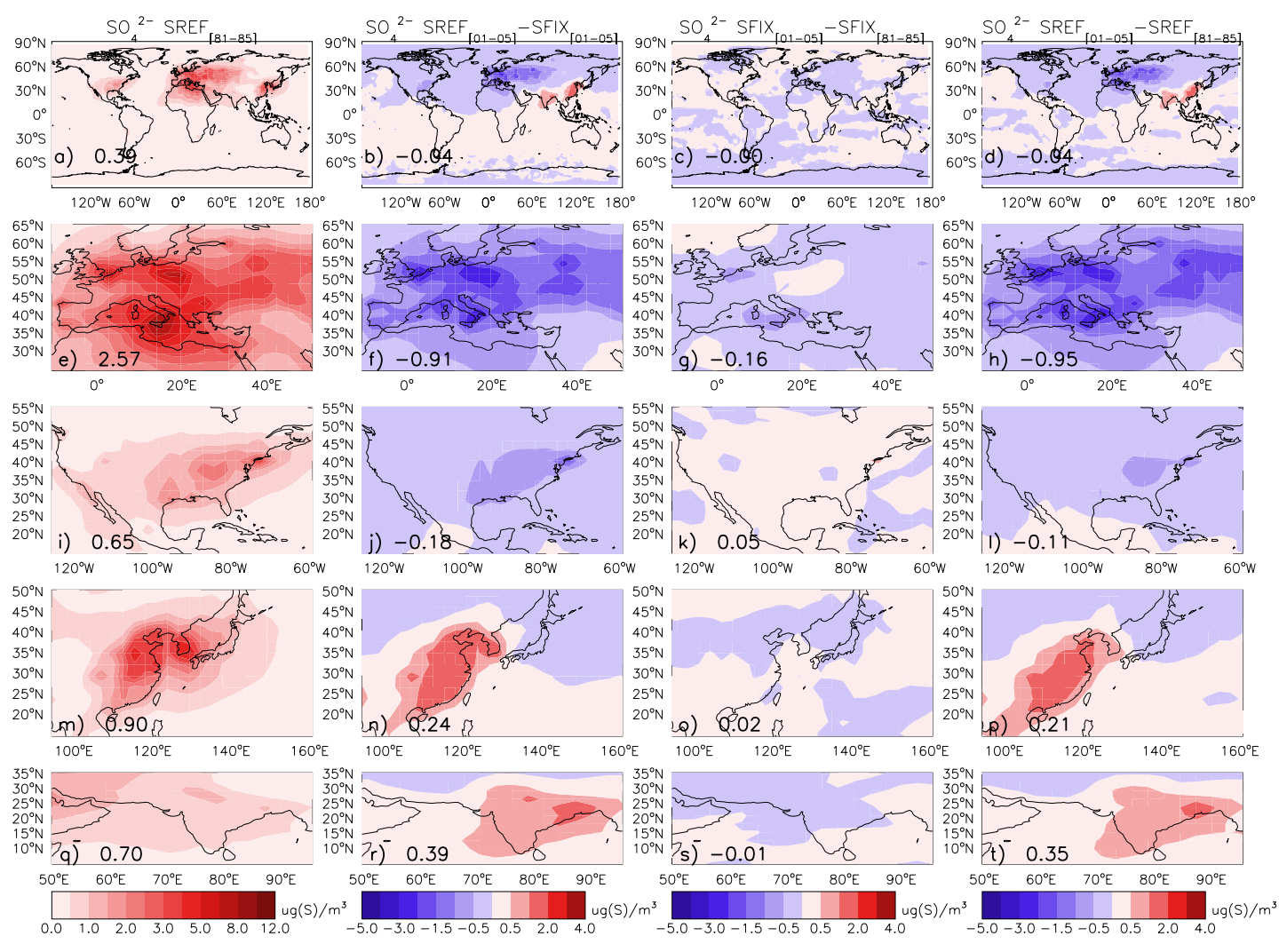

Fig. 10. As Fig. 5 but for $\mathrm{SO}_{4}^{2-}$ surface concentrations.

\subsubsection{South Asia}

Annual and regional average $\mathrm{SO}_{4}^{2-}$ surface concentrations of $0.70 \mu \mathrm{g}(\mathrm{S}) \mathrm{m}^{-3}$ (1981-1985) increased by on average $0.39 \mu \mathrm{g}(\mathrm{S}) \mathrm{m}^{-3}$, and up to $1 \mu \mathrm{g}(\mathrm{S}) \mathrm{m}^{-3}$ over India, due to the $220 \%$ increase in anthropogenic sulfur emissions in $25 \mathrm{yr}$. The alternation of wet and dry seasons is greatly influencing the seasonal $\mathrm{SO}_{4}^{2-}$ concentration changes. In winter (dry season), following the emissions, the $\mathrm{SO}_{4}^{2-}$ concentrations increase two-fold. In the wet season (JJA) we do not see a significant increase in $\mathrm{SO}_{4}^{2-}$ concentrations and the variability is almost completely dominated by the meteorology (Figs. 11d and $12 \mathrm{~d}$ ). This indicates that frequent rainfall in the monsoon circulation keeps $\mathrm{SO}_{4}^{2-}$ low regardless of increasing emissions. In winter we calculated a ratio of 0.45 between $\mathrm{SO}_{4}^{2-}$ wet deposition and total $\mathrm{SO}_{4}^{2-}$ production (both gas and liquid phases), while during summer months about 1.24 times more sulfur is deposited in the SA region than is produced.

\subsection{Variability of the global $\mathrm{SO}_{4}^{2-}$ budget}

We now analyze in more detail the processes that contribute to the variability of surface and column sulfate. Figure 13 shows that inter-annual variability of the global $\mathrm{SO}_{4}^{2-}$ burden is largely determined by meteorology in contrast to the sur- face $\mathrm{SO}_{4}^{2-}$ changes discussed above. In-cloud $\mathrm{SO}_{2}$ oxidation processes with $\mathrm{O}_{3}$ and $\mathrm{H}_{2} \mathrm{O}_{2}$ do not change significantly over 1980-2005 in the SFIX simulation $\left(47.2 \pm 0.4 \mathrm{Tg}(\mathrm{S}) \mathrm{yr}^{-1}\right)$, while in the SREF case the trend is very similar to those of the emissions. Interestingly, the $\mathrm{H}_{2} \mathrm{SO}_{4}$ (and aerosol) production resulting from the $\mathrm{SO}_{2}$ reaction with $\mathrm{OH}$ (Fig. 13c), responds differently to meteorological and emission variability than in-cloud oxidation. Globally it increased by $1 \mathrm{Tg}(\mathrm{S})$ between 1980 and late 1990s (SFIX), and then decreased again after the year 2000 (see also Fig. 4e). The increase of gas phase $\mathrm{SO}_{4}^{2-}$ production (Fig. 13c) in the SREF simulation is even more striking in the context of overall declining emissions. These contrasting temporal trends can be explained by the changes in the geographical distribution of the global emissions and the variation of the relative efficiency of the oxidation pathways of $\mathrm{SO}_{2}$ in SREF, which are given in Table 4. Thus the global increase in $\mathrm{SO}_{4}^{2-}$ gaseous phase production is disproportionally depending on the sulfur emissions over Asia, as noted earlier by e.g. Unger et al. (2009). For instance in the EU region the $\mathrm{SO}_{4}^{2-}$ burden increases by $2.2 \times 10^{-3} \operatorname{Tg}(\mathrm{S})$ per $\operatorname{Tg}(\mathrm{S})$ emitted, while this response is more than a factor of two higher in SA. Consequently, despite a global decrease in sulfur emissions of $8 \%$, the global burden is not significantly changing and the lifetime of $\mathrm{SO}_{4}^{2-}$ is slightly increasing by $5 \%$. 

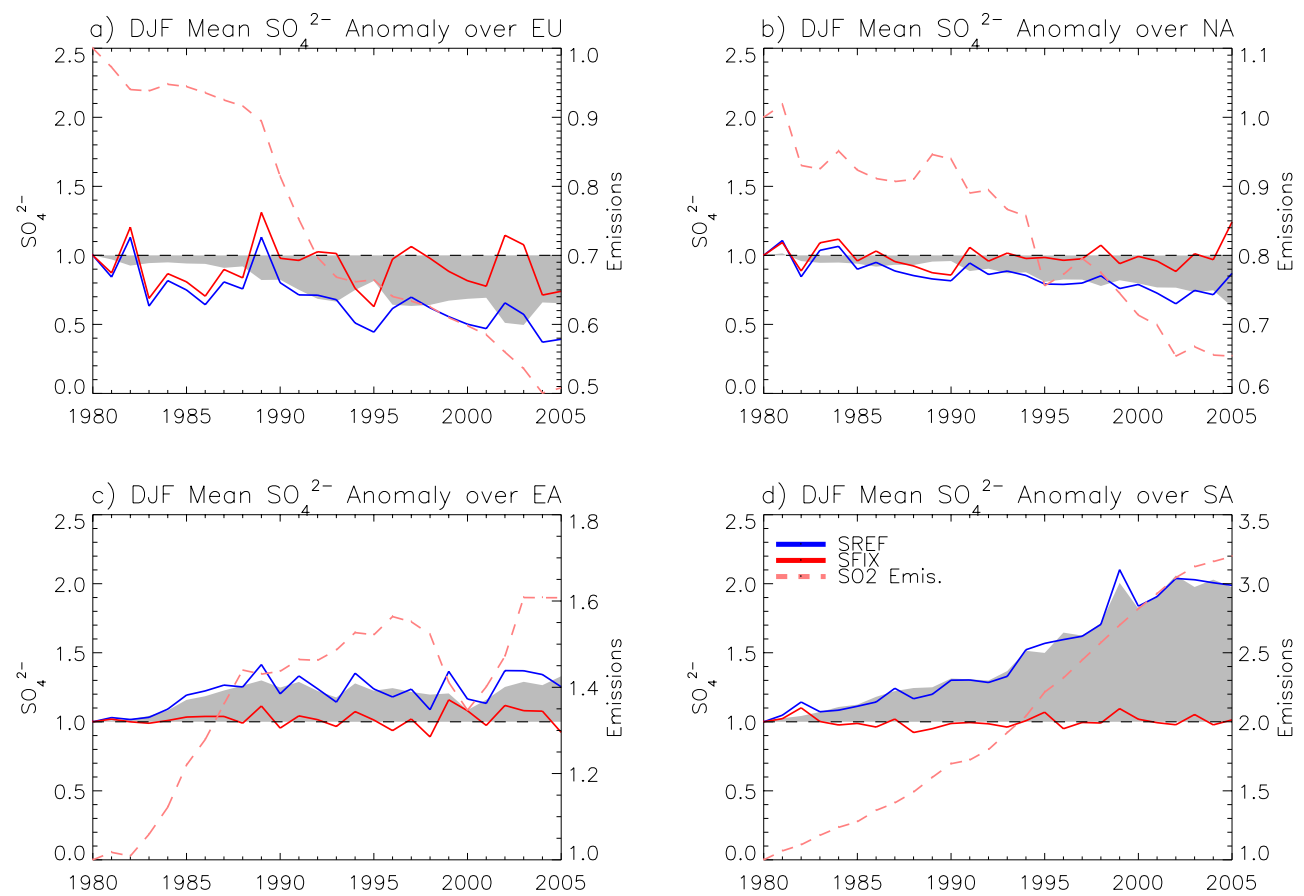

Fig. 11. Winter (DJF) anomalies of surface $\mathrm{SO}_{4}^{2-}$ concentrations averaged over the selected regions (shown in Fig. 1). On the left y-axis anomalies of $\mathrm{SO}_{4}^{2-}$ surface concentrations for the period 1980-2005 are expressed as the ratios between seasonal means for each year and the year 1980. The blue line represents the SREF simulation (changing meteorology and changing anthropogenic emissions), the red line the SFIX simulation (changing meteorology and fixed anthropogenic emissions at the level of 1980), while the gray area indicates the SREFSFIX difference. On the right $y$-axis the pink dashed line represents the changes, i.e. the ratio between each year and 1980, of total annual sulfur emissions.
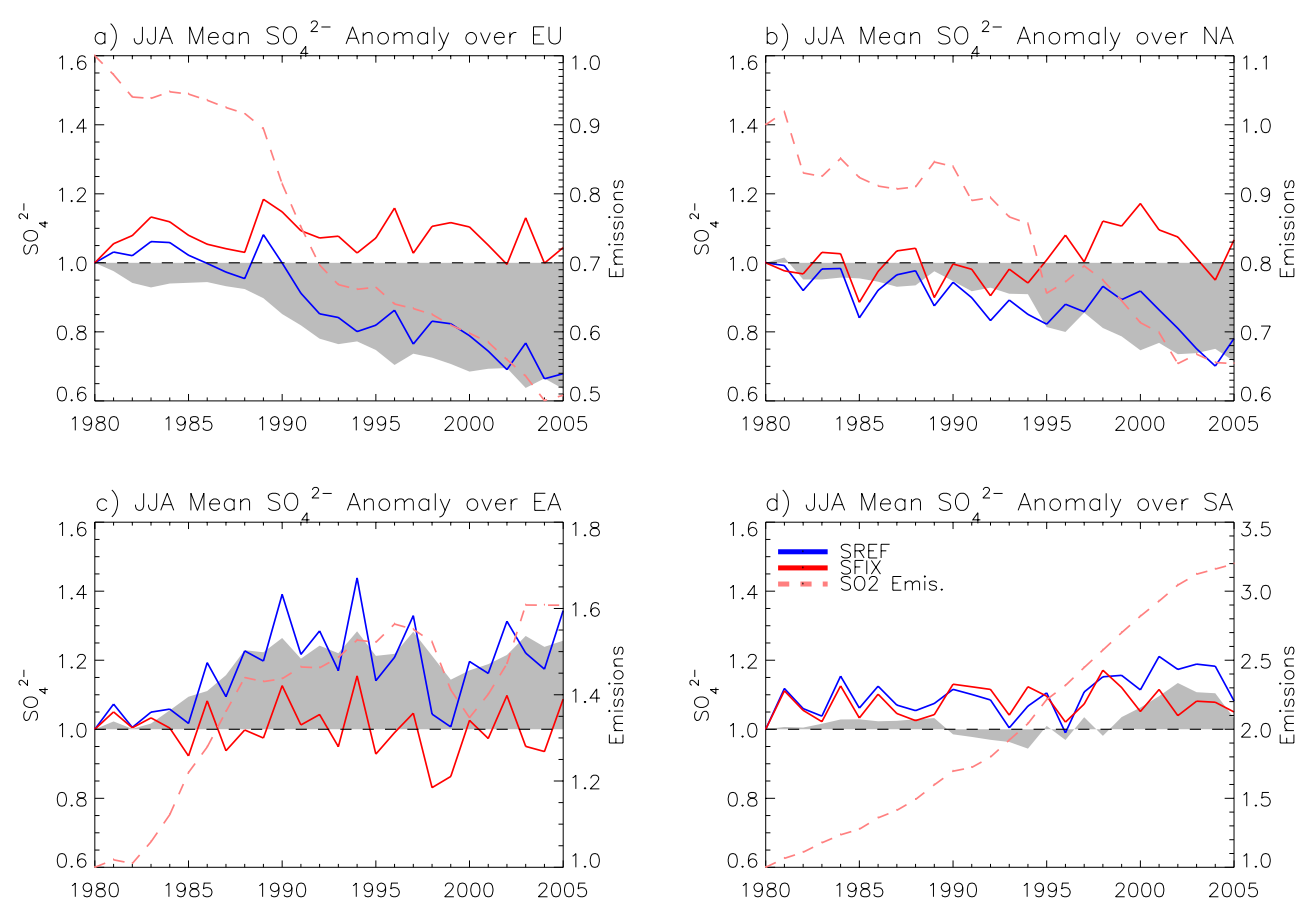

Fig. 12. As Fig. 11 for summer (JJA) anomalies of surface $\mathrm{SO}_{4}^{2-}$ concentrations. 

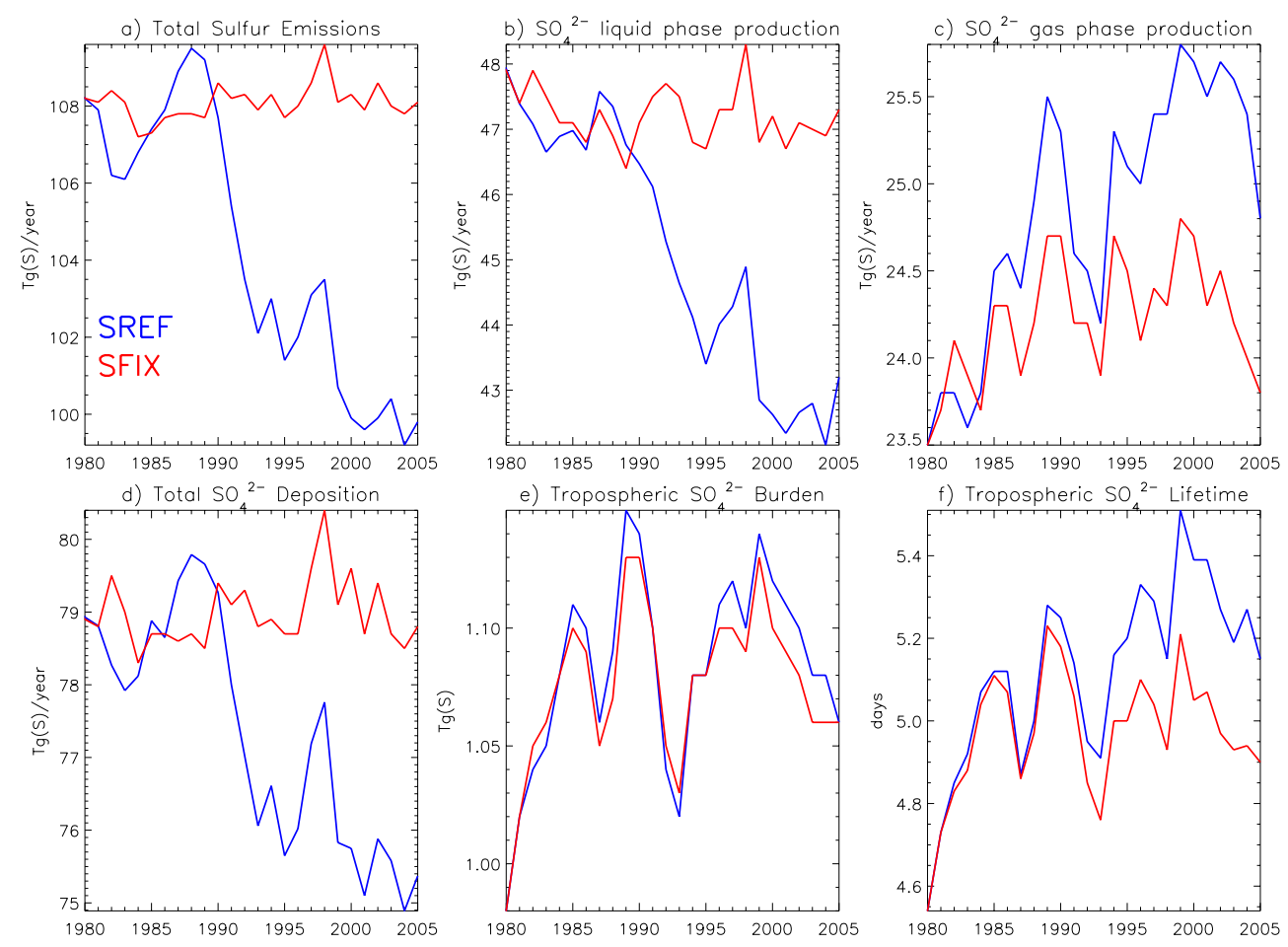

Fig. 13. Global tropospheric $\mathrm{SO}_{4}^{2-}$ budget calculated for the period 1980-2005 for the SREF (blue) and SFIX (red) ECHAM5-HAMMOZ simulations: (a) total sulfur emissions; (b) $\mathrm{SO}_{4}^{2-}$ liquid phase production; (c) $\mathrm{SO}_{4}^{2-}$ gaseous phase production; (d) surface deposition; (e) $\mathrm{SO}_{4}^{2-}$ burden; (f) lifetime.

\section{Variability of AOD and anthropogenic radiative perturbation of aerosol and $\mathrm{O}_{3}$}

The global annual average total aerosol optical depth (AOD) ranges between 0.151 and 0.167 during the period 19802005 (SREF), which is slightly higher than the range of model/measurement values $(0.127-0.151)$ reported by Kinne et al. (2006). The monthly mean anomalies of total AOD (Fig. 4f, $1 \sigma=0.007$ or $4.3 \%$ ) are determined by variations of natural aerosol emissions, including biomass burning; the changes in anthropogenic $\mathrm{SO}_{2}$ emissions discussed above only cause little differences in global AOD anomalies. The effect of anthropogenic emissions is more evident at the regional scale. Figure 14a shows the AOD 5-yr average calculated for the period 1981-1985, with a global average of 0.155. The changes in anthropogenic emissions (Fig. 14b) decrease AOD over a large part of the Northern Hemisphere, in particular over Eastern Europe, and they largely increase AOD over East and South Asia. The effect of meteorology and natural emissions is smaller, ranging between -0.05 and 0.1 (Fig. 14c), and it is almost linearly adding to the effect of anthropogenic emissions (Fig. 14d).

In Fig. 15 and Table 5 we see that over EU the reductions in anthropogenic emissions produced a $28 \%$ decrease in AOD, and $14 \%$ over NA. In EA and SA the increasing emissions, and particularly sulfur emissions, produced an in-
Table 4. Relationships, in $\operatorname{Tg}(\mathrm{S})$ per $\operatorname{Tg}(\mathrm{S})$ emitted, calculated for the period 1980-2005 between sulfur emissions and $\mathrm{SO}_{4}^{2-}$ burden (B), $\mathrm{SO}_{4}^{2-}$ production from $\mathrm{SO}_{2}$ in-cloud oxidation (In-cloud), and $\mathrm{SO}_{4}^{2-}$ gaseous phase production (Cond) over Europe (EU), North America (NA), East Asia (EA), and South Asia (SA).

\begin{tabular}{lcccccccc}
\hline & \multicolumn{2}{c}{ EU } & \multicolumn{2}{c}{ NA } & \multicolumn{2}{c}{ EA } & \multicolumn{2}{c}{ SA } \\
& slope & $R^{2}$ & slope & $R^{2}$ & slope & $R^{2}$ & slope & $R^{2}$ \\
\hline $\mathrm{B}\left(\times 10^{-3}\right)$ & 2.21 & 0.86 & 0.79 & 0.12 & 2.86 & 0.79 & 5.36 & 0.90 \\
In-cloud & 0.31 & 0.97 & 0.38 & 0.93 & 0.25 & 0.79 & 0.18 & 0.90 \\
Cond & 0.08 & 0.93 & 0.09 & 0.70 & 0.17 & 0.85 & 0.37 & 0.98 \\
\hline
\end{tabular}

crease of AOD of $19 \%$ and $26 \%$, respectively. The variability in AOD due to natural aerosol emissions and meteorology is significant. In SFIX the natural variability of AOD is up to $10 \%$ over EU, $17 \%$ over NA, $8 \%$ over EA, and $13 \%$ over SA. Interestingly, over NA the resulting AOD in the SREF simulation does not show a large signal. The same results were qualitatively found also from satellite observations (Wang et al., 2009), where the AOD decreased only over Europe, no significant trend was found for North America, and it increased in Asia.

In Table 5 we present an analysis of the radiative perturbations due to aerosol and ozone comparing the periods 
Table 5. Globally and regionally (EU, NA, EA, and SA) averaged effect of changing anthropogenic emissions (SREF-SFIX) during the 5-yr periods 1981-1985 and 2001-2005 on: surface concentrations of $\mathrm{O}_{3}$ (ppbv), $\mathrm{SO}_{4}^{2-}$ (\%), and $\mathrm{BC}$ (\%); total aerosol optical depth (AOD) (\%) and total column $\mathrm{O}_{3}(\mathrm{DU})$; the total anthropogenic aerosol radiative perturbation at top of the atmosphere $\left(\mathrm{RP}_{\mathrm{aer}}^{\mathrm{TOA}}\right)$, at surface $\left(\mathrm{RP}_{\mathrm{aer}}^{\mathrm{SUF}}\right)$ $\left(\mathrm{W} \mathrm{m}^{-2}\right)$, and in the atmosphere $\left(\mathrm{RP}_{\mathrm{aer}}^{\mathrm{ATM}}=\left(\mathrm{RP}_{\mathrm{aer}}^{\mathrm{TOA}}-\mathrm{RP}_{\mathrm{aer}}^{\mathrm{SURF}}\right)\right.$; the anthropogenic radiative perturbation of $\mathrm{O}_{3}\left(\mathrm{RP}_{\mathrm{O}_{3}}\right)$; correlations calculated over the entire period 1980-2005 between anthropogenic $\mathrm{RP}_{\mathrm{aer}}^{\mathrm{TOA}}$ and $\triangle \mathrm{AOD}$; between anthropogenic $\mathrm{RP}_{\text {aer }}^{\mathrm{SUR}}$ and $\triangle \mathrm{AOD}$; between $\mathrm{RP}_{\mathrm{aer}}^{\mathrm{ATM}}$ and $\Delta \mathrm{AOD}$; between $\mathrm{RP}_{\mathrm{aer}}^{\mathrm{ATM}}$ and $\Delta \mathrm{BC}$; between anthropogenic $\mathrm{RP}_{\mathrm{O}_{3}}$ and $\Delta \mathrm{O}_{3}$ at surface; between anthropogenic $\mathrm{RP}_{\mathrm{O}_{3}}$ and $\Delta \mathrm{O}_{3}$ column. High correlation coefficients are highlighted in bold.

\begin{tabular}{|c|c|c|c|c|c|c|c|c|c|c|}
\hline & \multicolumn{2}{|c|}{ GLOBAL } & \multicolumn{2}{|c|}{$\mathrm{EU}$} & \multicolumn{2}{|c|}{ NA } & \multicolumn{2}{|c|}{ EA } & \multicolumn{2}{|c|}{ SA } \\
\hline$\Delta \mathrm{O}_{3}[\mathrm{ppb}]$ & \multicolumn{2}{|c|}{0.98} & \multicolumn{2}{|c|}{0.81} & \multicolumn{2}{|c|}{0.27} & \multicolumn{2}{|c|}{2.44} & \multicolumn{2}{|c|}{4.25} \\
\hline$\Delta \mathrm{SO}_{4}^{2-}[\%]$ & \multicolumn{2}{|c|}{-10} & \multicolumn{2}{|c|}{-36} & \multicolumn{2}{|c|}{-25} & \multicolumn{2}{|c|}{27} & \multicolumn{2}{|c|}{59} \\
\hline$\Delta \mathrm{BC}[\%]$ & \multicolumn{2}{|c|}{0} & \multicolumn{2}{|c|}{-43} & \multicolumn{2}{|c|}{-34} & \multicolumn{2}{|c|}{30} & \multicolumn{2}{|c|}{70} \\
\hline$\Delta \mathrm{AOD}[\%]$ & \multicolumn{2}{|l|}{0} & \multicolumn{2}{|c|}{-28} & \multicolumn{2}{|c|}{-14} & \multicolumn{2}{|c|}{19} & \multicolumn{2}{|c|}{26} \\
\hline$\Delta \mathrm{O}_{3}[\mathrm{DU}]$ & \multicolumn{2}{|c|}{1.18} & \multicolumn{2}{|c|}{1.35} & \multicolumn{2}{|c|}{1.54} & \multicolumn{2}{|c|}{2.85} & \multicolumn{2}{|c|}{2.99} \\
\hline $\mathrm{RP}_{\mathrm{aer}}^{\mathrm{TOA}}\left[\mathrm{W} \mathrm{m}^{-2}\right]$ & \multicolumn{2}{|c|}{0.02} & \multicolumn{2}{|c|}{1.26} & \multicolumn{2}{|c|}{0.39} & \multicolumn{2}{|c|}{-0.53} & \multicolumn{2}{|c|}{-0.54} \\
\hline $\mathrm{RP}_{\mathrm{aer}}^{\mathrm{SURF}}\left[\mathrm{W} \mathrm{m}^{-2}\right]$ & -0.0 & & 2.0 & & 0.7 & & -1.1 & & -1.8 & \\
\hline $\mathrm{RP}_{\mathrm{aer}}^{\mathrm{ATM}}\left[\mathrm{W} \mathrm{m}^{-2}\right]$ & 0.0 & & -0.7 & & -0 . & & 0.66 & & 1.29 & \\
\hline $\mathrm{RP}_{\mathrm{O}_{3}}\left[\mathrm{~W} \mathrm{~m}^{-2}\right]$ & 0.0 & & 0.0 & & 0.0 & & 0.12 & & 0.15 & \\
\hline & slope & $R^{2}$ & slope & $R^{2}$ & slope & $R^{2}$ & slope & $R^{2}$ & slope & $R^{2}$ \\
\hline $\mathrm{RP}_{\mathrm{aer}}^{\mathrm{TOA}}\left[\mathrm{W} \mathrm{m}^{-2}\right]$ vs. $\triangle \mathrm{AOD}$ & -17.86 & 0.85 & -16.1 & 0.99 & -16.99 & 0.97 & -13.57 & 0.99 & -13.84 & 0.99 \\
\hline $\mathrm{RP}_{\mathrm{aer}}^{\mathrm{SURF}}\left[\mathrm{W} \mathrm{m}^{-2}\right]$ vs. $\triangle \mathrm{AOD}$ & -1.32 & 0.24 & -26.71 & 0.99 & -28.10 & 0.97 & -28.95 & 0.99 & -47.57 & 0.99 \\
\hline $\mathrm{RP}_{\mathrm{aer}}^{\mathrm{ATM}}\left[\mathrm{W} \mathrm{m}{ }^{-2}\right]$ vs. $\Delta \mathrm{AOD}$ & -4.62 & 0.03 & 10.61 & 0.93 & 11.11 & 0.68 & 15.38 & 0.97 & 33.73 & 0.98 \\
\hline $\mathrm{RP}_{\mathrm{aer}}^{\mathrm{ATM}}\left[\mathrm{W} \mathrm{m}^{-2}\right]$ vs. $\triangle \mathrm{BC}[\%]$ & 0.35 & 0.11 & 1.73 & 0.99 & 0.95 & 0.99 & 1.92 & 0.97 & 1.74 & 0.99 \\
\hline $\mathrm{RP}_{\mathrm{O}_{3}}\left[\mathrm{~mW} \mathrm{~m}^{-2}\right]$ vs. $\Delta \mathrm{O}_{3}[\mathrm{ppbv}]$ & 42.8 & 0.91 & 35.2 & 0.65 & 51.3 & 0.49 & 46.7 & 0.94 & 36.0 & 0.97 \\
\hline $\mathrm{RP}_{\mathrm{O}_{3}}\left[\mathrm{~mW} \mathrm{~m}^{-2}\right]$ vs. $\Delta \mathrm{O}_{3}[\mathrm{DU}]$ & 40.8 & 0.99 & 36.4 & 0.99 & 44.2 & 0.99 & 44.1 & 0.99 & 49.1 & 0.99 \\
\hline
\end{tabular}

1981-1985 and 2001-2005. We define the difference between the instantaneous clear-sky total aerosol and all sky $\mathrm{O}_{3} \mathrm{RF}$ of the SREF and SFIX simulations, as the total aerosol and $\mathrm{O}_{3}$ short-wave radiative perturbation due to anthropogenic emissions, and we will refer to them as $\mathrm{RP}_{\text {aer }}$ and $\mathrm{RP}_{\mathrm{O}_{3}}$, respectively.

\subsection{Aerosol radiative perturbation}

The instantaneous aerosol radiative forcing (RF) in ECHAM5-HAMMOZ is diagnostically calculated from the difference in the net radiative fluxes including and excluding aerosol (Stier et al., 2007). For aerosol we focus on clear sky radiative forcing, since unfortunately a coding error prevents us from evaluating all-sky forcing. In Fig. 15 we show, together with the AOD (see before), the evolution of the normalized $\mathrm{RP}_{\mathrm{aer}}$, at the top-of-the-atmosphere $\left(\mathrm{RP}_{\mathrm{aer}}^{\mathrm{TOA}}\right)$ and at the surface (and $\mathrm{RP}_{\mathrm{aer}}^{\mathrm{Surf}}$ ).

For Europe, the AOD change by $-28 \%$ (mainly due to changes in removal of $\mathrm{SO}_{4}^{2-}$ aerosol) leads to an increase of $\mathrm{RP}_{\text {aer }}^{\mathrm{TOA}}$ of $1.26 \mathrm{~W} \mathrm{~m}^{-2}$ and $\mathrm{RP}_{\mathrm{aer}}^{\mathrm{Surf}}$ of 2.05 . The $14 \% \mathrm{AOD}$ reduction in NA corresponds to a $\mathrm{RP}_{\mathrm{aer}}^{\mathrm{TOA}}$ of $0.39 \mathrm{~W} \mathrm{~m}^{-2}$ and $\mathrm{RP}_{\mathrm{aer}}^{\text {Surf }}$ of $0.71 \mathrm{~W} \mathrm{~m}^{-2}$. In EA and SA, AOD increased by $19 \%$ and $26 \%$, corresponding to a $\mathrm{RP}_{\mathrm{aer}}^{\mathrm{TOA}}$ of -0.53 and $-0.54 \mathrm{~W} \mathrm{~m}^{-2}$, respectively, while at surface we found $\mathrm{RP}_{\text {aer }}$ of $-1.19 \mathrm{~W} \mathrm{~m}^{-2}$ and $-1.83 \mathrm{~W} \mathrm{~m}^{-2}$. The larger difference between TOA and surface forcing in South Asia compared to the other regions indicates a much larger contribution of $\mathrm{BC}$ absorption in South Asia.

Globally, we found a significant correlation between the anthropogenic aerosol radiative perturbation at the top of the atmosphere with the percentage changes in AOD due to anthropogenic emissions (Table $5, R^{2}=0.85$ for $\mathrm{RP}_{\mathrm{aer}}^{\mathrm{TOA}}$ vs. $\triangle \mathrm{AOD}$ ), while there is no correlation between anthropogenic aerosol radiative perturbation and anthropogenic changes in AOD $(\triangle \mathrm{AOD})$ or $\mathrm{BC}(\triangle \mathrm{BC})$ at the surface and in the atmosphere. Within the four selected regions the correlation between anthropogenic emission induced changes in AOD and $\mathrm{RP}_{\text {aer }}$ at the top-of-the-atmosphere, surface and the atmosphere is much higher $\left(R^{2}>0.93\right.$ for all regions except for $\mathrm{RP}_{\mathrm{aer}}^{\mathrm{ATM}}$ over NA; Table 5).

We calculate a relatively constant $\mathrm{RP}_{\mathrm{aer}}^{\mathrm{TOA}}$ between -17 to $-13 \mathrm{~W} \mathrm{~m}^{-2}$ per unit AOD around the world; and a larger range of -48 to $-26 \mathrm{~W} \mathrm{~m}^{-2}$ per unit $\mathrm{AOD}$ for $\mathrm{RP}_{\mathrm{aer}}$ at the surface. The atmospheric absorption by aerosol $\mathrm{RP}_{\text {aer }}$ (calculated from the difference of RP at TOA and RP at the surface) is around $10 \mathrm{~W} \mathrm{~m}^{-2}$ in EU and NA, $15 \mathrm{~W} \mathrm{~m}^{-2}$ in EA, and $34 \mathrm{~W} \mathrm{~m}^{-2}$ in SA, showing the importance of absorbing $\mathrm{BC}$ aerosols in determining surface and atmospheric forcing, as confirmed by the high correlations of $\mathrm{RP}_{\mathrm{aer}}^{\mathrm{ATM}}$ with surface black carbon levels. 

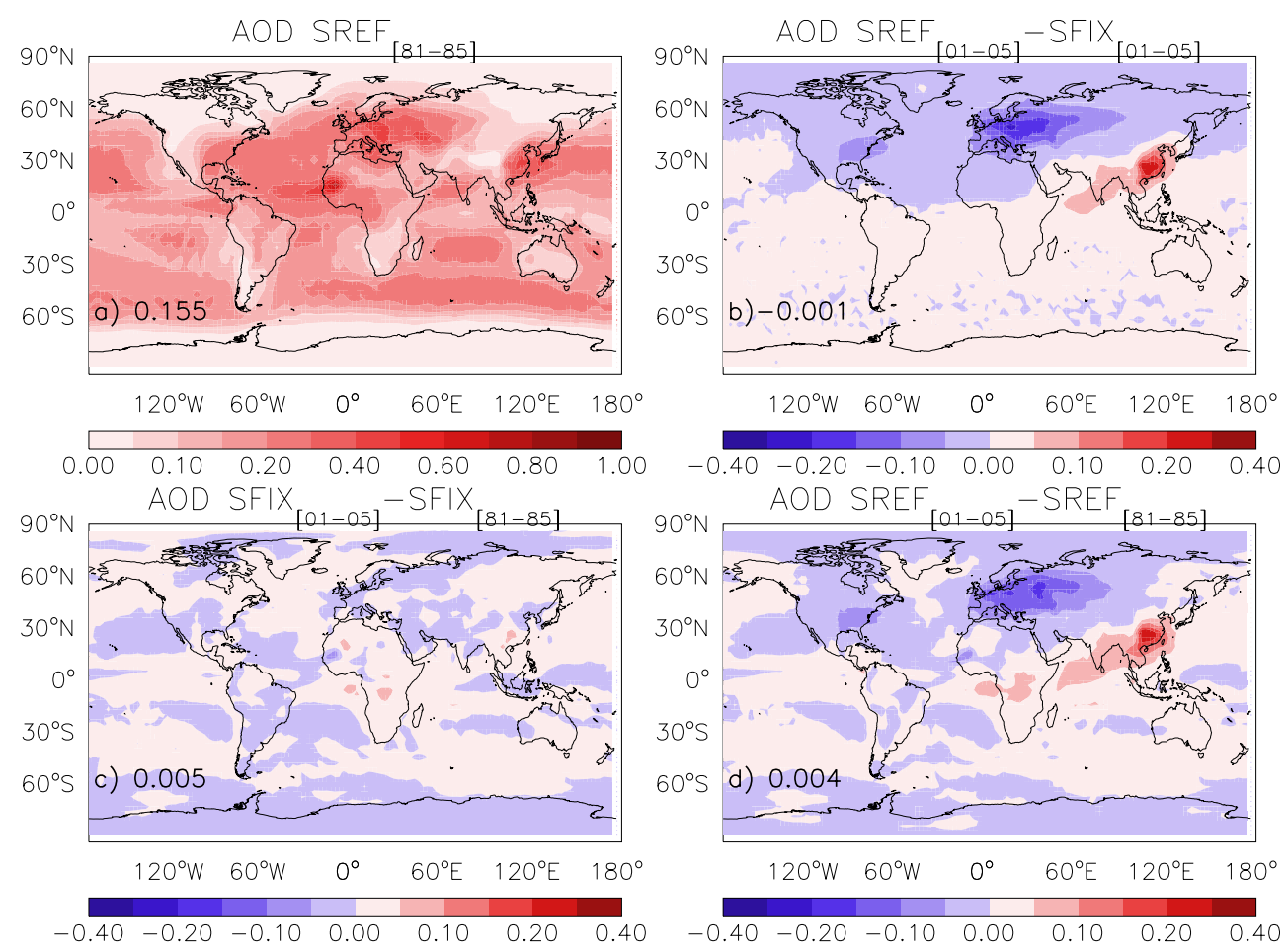

Fig. 14. Maps of total aerosol optical depth (AOD) and the changes due to anthropogenic emissions and natural variability. We show (a) the 5-yr averages (1981-1985) of global AOD; (b) the effect of anthropogenic emission changes in the period 2001-2005 on AOD, calculated as the difference between SREF and SFIX simulations; (c) the natural variability of AOD, which is due to natural emissions and meteorology in the simulated $25 \mathrm{yr}$, calculated as the difference between the 5-yr average periods (2001-2005) and (1981-1985) in the SFIX simulation; (d) the combined effect of anthropogenic emissions and natural variability expressed as the difference between the 5-yr average period (2001-2005)-(1981-1985) in the SREF simulation.

\subsection{Ozone radiative perturbation}

For convenience and completeness, we also present in this section a calculation of $\mathrm{O}_{3} \mathrm{RP}$ diagnosed using ECHAM5HAMMOZ $\mathrm{O}_{3}$ columns, in combination with all-sky radiative forcing efficiencies provided by D. Stevenson (personal communication, 2008; for a further discussion, Gauss et al., 2006). Table 5 and Fig. 5 show that $\mathrm{O}_{3}$ total column and surface concentrations increased by $1.54 \mathrm{DU}(1.58 \mathrm{ppbv})$ over NA, 1.35 DU (1.28 ppbv) over EU, 2.85 (4.13 ppbv) over EA, and 2.99 DU (5.12 ppbv) over SA in the period 19802005. The $\mathrm{RP}_{\mathrm{O}_{3}}$ over the different regions reflect the total column $\mathrm{O}_{3}$ changes, $0.05 \mathrm{~W} \mathrm{~m}^{-2}$ over $\mathrm{EU}, 0.06 \mathrm{~W} \mathrm{~m}^{-2}$ over $\mathrm{NA}, 0.12 \mathrm{~W} \mathrm{~m}^{-2}$ over EA, and $0.15 \mathrm{~W} \mathrm{~m}^{-2}$ over SA. As expected, the spatial correlation of $\mathrm{O}_{3}$ columns and radiative perturbations is nearly 1 , also the surface $\mathrm{O}_{3}$ concentrations in EA and SA correlate nearly as well with the radiative perturbation. The lower correlations in EU and NA suggest that a substantial fraction of the ozone production from emissions in NA and EU takes place above the boundary layer (Table 5).

\section{Summary and conclusions}

We used the coupled aerosol-chemistry-climate general circulation model ECHAM5-HAMMOZ, constrained with $25 \mathrm{yr}$ of meteorological data from ECMWF, and a compilation of recent emission inventories, to evaluate the response of atmospheric concentrations, aerosol optical depth and radiative perturbations to anthropogenic emission changes and natural variability over the period 1980-2005. The focus of our study was on $\mathrm{O}_{3}$ and $\mathrm{SO}_{4}^{2-}$, for which most long-term surface observations in the period 1980-2005 were available. The main findings are summarized in the following points.

- We compiled a gridded database of anthropogenic CO, VOC, $\mathrm{NO}_{\mathrm{x}}, \mathrm{SO}_{2}, \mathrm{BC}$, and $\mathrm{OC}$ emissions, utilizing reported regional emission trends. Globally, anthropogenic $\mathrm{NO}_{\mathrm{x}}$ and $\mathrm{OC}$ emissions increased by $10 \%$, while sulfur emissions decreased by $10 \%$ from 1980 to 2005. Regional emission changes were larger, e.g. all components decreased by $10-50 \%$ in North America and Europe, but increased between $40-220 \%$ in East and South Asia.

- Natural emissions were calculated on-line and depended on inter-annual changes in meteorology. We 

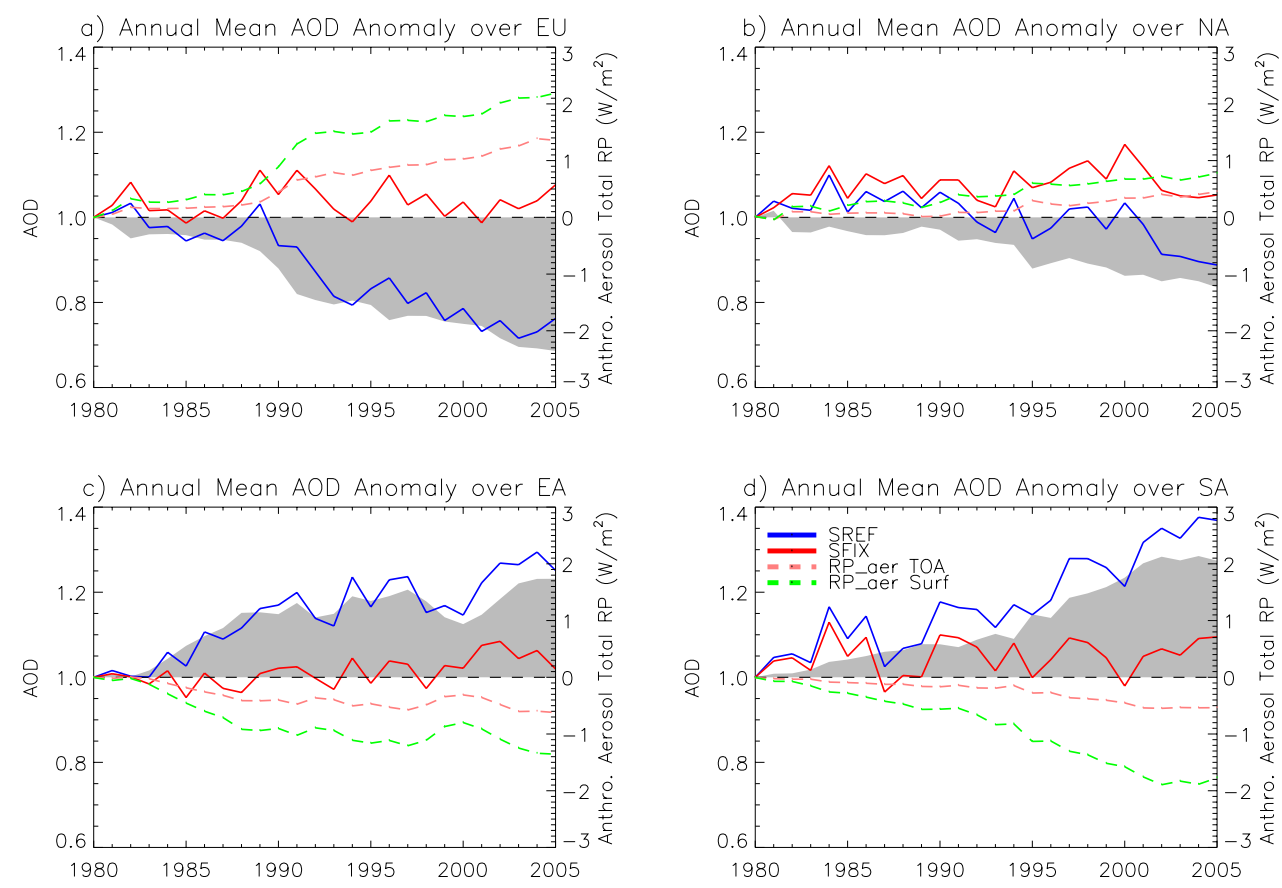

Fig. 15. Annual anomalies of total aerosol optical depth (AOD) averaged over the selected regions (shown in Fig. 1). On the left y-axis anomalies of AOD for the period 1980-2005 are expressed as the ratios between annual means for each year and 1980. The blue line represents the SREF simulation (changing meteorology and changing anthropogenic emissions), the red line the SFIX simulation (changing meteorology and fixed anthropogenic emissions at the level of 1980), while the gray area indicates the SREF-SFIX difference. On the right $\mathrm{y}$-axis the pink and green dashed lines represent the clear-sky aerosol anthropogenic radiative perturbation at the top of the atmosphere $\left(\mathrm{RP}_{\mathrm{aer}}^{\mathrm{TOA}}\right)$ and at the surface $\left(\mathrm{RP}_{\mathrm{aer}}^{\mathrm{Surf}}\right)$, respectively.

found a rather small global inter-annual variability for biogenic VOCs emissions ( $3 \%$ of the multi-annual average), DMS (1\%), and sea salt aerosols $(2 \%)$. A larger variability was found for lightning $\mathrm{NO}_{\mathrm{x}}$ emissions $(5 \%)$ and mineral dust $(10 \%)$. Generally we could not identify a clear trend for natural emissions, except for a small decreasing trend of lightning $\mathrm{NO}_{\mathrm{x}}$ emissions $\left(0.017 \pm 0.007 \mathrm{Tg}(\mathrm{N}) \mathrm{yr}^{-1}\right)$.

- The impacts of natural variability (including meteorology, biogenic VOC emissions, biomass burning emissions and lightning) on surface ozone, tropospheric $\mathrm{OH}$ and AOD are often larger than the impacts due to anthropogenic emission changes. Two important meteorological drivers for atmospheric composition change humidity and temperature - are strongly correlated. The moderate correlation $(R=0.43)$ of the global mean annual surface ozone concentration and surface temperature suggests important contributions of other processes to the tropospheric ozone budget.

- The set-up of this study does not allow to specifically investigate the contribution of meteorological parameters to changes in the chemical composition except in a few cases where major events such as the 1997-1998 ENSO lead to strong enhancements of surface ozone and AOD beyond the response that is expected from the changes of natural emissions.

- Global surface $\mathrm{O}_{3}$ increased in $25 \mathrm{yr}$ on average by $0.48 \mathrm{ppbv}$ due to anthropogenic emissions, but $75 \%$ of the inter-annual variability of the multi-annual monthly surface ozone was related to natural variations.

- The seasonally averaged modeled and measured surface ozone concentrations are reasonably well correlated for a large number of North American and European stations. However this is not always an indication that the observed trends are correctly reproduced. A regional analysis suggests that changing anthropogenic emissions increased $\mathrm{O}_{3}$ on average by $0.8 \mathrm{ppbv}$ in $\mathrm{Eu}-$ rope, with large differences between southern and other parts of Europe, which is generally a larger response compared to the HTAP study (Fiore et al., 2009). Measurements qualitatively confirm these trends in Europe. However, the observed trends are up to a factor of 3 (0.3-0.5 $\left.\mathrm{ppbv} \mathrm{yr}^{-1}\right)$ larger than those that are calculated, especially in winter, while in summer the small negative trends simulated be the model were not confirmed by the measurements. In North America anthropogenic emissions slightly increased $\mathrm{O}_{3}$ by $0.3 \mathrm{ppbv}$ on average, even though decreases between 1 and 2 ppbv were 
calculated over a large fraction of the US. Annual averages hid some seasonal discrepancies between model results and observed trends. In East Asia, we computed an increase of surface $\mathrm{O}_{3}$ by $4.1 \mathrm{ppbv}, 2.4 \mathrm{ppbv}$ from anthropogenic emissions and $1.6 \mathrm{ppbv}$ contribution from meteorological changes. The scarce long-term observational datasets (mostly Japanese stations) do not contradict these computed trends. In $25 \mathrm{yr}$, annual mean $\mathrm{O}_{3}$ concentrations increased by $5.1 \mathrm{ppbv}$ over $\mathrm{SA}$, with approximately $75 \%$ related to increasing anthropogenic emissions. Confidence in the calculations of $\mathrm{O}_{3}$ and $\mathrm{O}_{3}$ trends is low, since the few available measurements suggest much lower $\mathrm{O}_{3}$ over India.

- The tropospheric $\mathrm{O}_{3}$ budget and variability agree well with earlier studies by Stevenson et al. (2006) and Hess and Mahowald (2009). During 1980-2005 we calculate an intensification of tropospheric $\mathrm{O}_{3}$ chemistry, leading to an increase of global tropospheric ozone by $3 \%$ and a decreasing $\mathrm{O}_{3}$ lifetime by $4 \%$. Comparing similar reanalysis studies, such as our study and Hess and Mahowald (2009), it is shown that the choice of the reanalysis product and nudging method has strong impacts on variability of $\mathrm{O}_{3}$ and other components. For instance the comparison of our study with an alternative data assimilation technique presented by Hess and Mahowald (2009), i.e. prescribing sea-surfacetemperatures (often used in climate modeling time slice experiments) resulted in substantially less agreement. Even if the main large-scale meteorological patterns are captured by prescribing SSTs in a GCM simulation, the modeled dynamics in a GCM constrained by a full nudging methodology should be closer to the observed meteorology. Therefore we suggest that it is also more consistent when comparing simulated chemical composition with observations. However, we have not performed the simulations with prescribed SSTs ourselves, and the forthcoming ACC-Hindcast and ACC-MIP programs should shed the light on this matter.

- Global $\mathrm{OH}$, which determines the oxidation capacity of the atmosphere, decreased by $-0.27 \% \mathrm{yr}^{-1}$ due to natural variability, of which lightning was the most important contributor. Anthropogenic emissions changes caused an opposite trend of $0.25 \% \mathrm{yr}^{-1}$ thus nearly balancing the natural emission trend. Calculated interannual variability is in the order of $1.6 \%$, in disagreement with the earlier study of Prinn et al. (2005) of large inter-annual fluctuations on the order of $10 \%$, but closer to the estimates of Dentener et al. (2003) $(1.8 \%)$ and Montzka et al. (2011) (2\%).

- The global inter-annual variability of surface $\mathrm{SO}_{4}^{2-}$ $(10 \%)$ is strongly determined by regional variations of emissions. Comparison of computed trends with measurements in Europe and North America showed in gen- eral good agreement. Seasonal trend analysis gave additional information. For instance, in Europe, measurements suggest similar downward trends of 0.05$0.1 \mu \mathrm{g}(\mathrm{S}) \mathrm{m}^{-3} \mathrm{yr}^{-1}$ in both summer and winter, while simulated surface $\mathrm{SO}_{4}^{2-}$ downward trends are somewhat stronger in winter than in summer. In North America, in winter the model reproduces the observed $\mathrm{SO}_{4}^{2-}$ declines well in some, but not all regions. In summer computed trends are generally underestimated by up to $50 \%$. We expect that a misrepresentation of temporal variations of emissions, together with non-linear oxidation chemistry, could play a role in these winter-summer differences. In East and South Asia the model results suggest increases of surface $\mathrm{SO}_{4}^{2-}$ by ca. $30 \%$, however to our knowledge no datasets are available that could corroborate these results.

- Trend and variability of sulfate columns are very different from surface $\mathrm{SO}_{4}^{2-}$. Despite a global decrease of $\mathrm{SO}_{4}^{2-}$ emissions from 1980 to 2005, global sulfate burdens were not significantly changing, due to a southward shift of $\mathrm{SO}_{2}$ emissions, which determines a more efficient production and longer lifetime of $\mathrm{SO}_{4}^{2-}$.

- Globally surface $\mathrm{SO}_{4}^{2-}$ concentration decreases by ca. $0.1 \mu \mathrm{g}(\mathrm{S}) \mathrm{m}^{-3}$, while the global AOD increases by ca. 0.01 (or ca. $5 \%$ ), the latter driven by variability of dust and sea salt emissions. Regionally anthropogenic emissions changes are more visible: we calculate a significant decline of AOD over Europe (28\%), a relatively constant AOD over North America (it decreased only by $14 \%$ in the last $5 \mathrm{yr}$ ), and a strongly increase over East (19\%) and South Asia (26\%). These results differ substantially from Streets et al. (2009). Since the emission inventory used in this study and the one by Streets et al. (2009) are very similar, we expect that our explicit treatment of aerosol chemistry and microphysics lead to very different results than the scaling of AOD with emission trends used by Streets et al. (2009). Our analysis suggests that the impact of anthropogenic emission changes on radiative perturbations is typically larger and more regional at the surface than at the top-of-the atmosphere, with a strong atmospheric warming by $\mathrm{BC}$ aerosol specifically over South Asia. The global top-of-the-atmosphere radiative perturbation follows more closely aerosol optical depth, reflecting large-scale $\mathrm{SO}_{4}^{2-}$ dispersion patterns. Nevertheless, our study corroborates an important role for aerosol in explaining the observed changes in surface radiation over Europe (Wild, 2009; Wang et al., 2009). Our study is also qualitatively consistent with the reported worldwide visibility decline (Wang et al., 2009). In Europe our calculated AOD reductions are consistent with improving visibility (Wang et al., 2009) and increasing surface radiation (Wild, 2009). $\mathrm{O}_{3}$ radiative perturbations 
(not including feedbacks of $\mathrm{CH}_{4}$ ) are regionally much smaller than aerosol RPs, but globally equal to or larger than aerosol RPs.

\section{Outlook}

Our re-analysis study showed that several of the overall processes determining the variability and trend of $\mathrm{O}_{3}$ and aerosols are qualitatively understood- but also that many of the details are not well included. As such it gives some trust in our ability to predict the future impacts of aerosol and reactive gases on climate, but it also shows that many model parameterizations need further improvement for more reliable predictions. For example the variability due to stratosphere/troposphere $\mathrm{O}_{3}$ fluxes is not included in our study, and the description of lightning and biogenic emissions are characterized by large uncertainties. We have seen that aerosol variability, and in particular sulfate, is mainly driven by emissions. Improving the description of anthropogenic emission inventories, natural emission parameterizations, and the description of secondary formation of aerosols (e.g. secondary organic aerosols (SOA), which are not included in this study) may improve our understanding of aerosol variability. It is our feeling that comparisons focussing on 1 or $2 \mathrm{yr}$ of data, while useful by itself, may mask issues with compensating errors, and wrong sensitivities. Re-analysis studies are useful tools to unmask these model deficiencies. The analysis of summer and winter differences in trends and variability was particularly insightful in our study, since it highlights our level of understanding of the relative importance of chemical and meteorological processes. The separate analysis of the influence of meteorology and anthropogenic emissions changes is of direct importance for the understanding and attribution of observed trends to emission controls. The analysis of differences in regional patterns again highlights our understanding of different processes.

The ECHAM5-HAMMOZ model is, like most other climate models, continuously being improved. For instance, the overestimate of surface $\mathrm{O}_{3}$ in many world regions or the poor representation in a tropospheric model of the stratospheretroposphere exchange (STE) fluxes (as reported by this study, Rast et al., 2011 and Schultz et al., 2007), reduces our trust in our trend analysis, and should be urgently addressed. Participation in model inter-comparisons, and comparison of model results to intensive measurement campaigns of multiple components may help to identify deficiencies in the model process descriptions. Improvement of parameterizations and model resolution will improve in the long run the model performances. Continued efforts are needed to improve our knowledge of anthropogenic and natural emissions in the past decades, which will help to understand better recent trends and variability of ozone and aerosols. New reanalysis products, such as the re-analyses from ECMWF and NCEP are frequently becoming available, and should give improved constraints for the meteorological conditions. It is of outmost importance that the few long-term measurement datasets are being continued, and that long-term commitments are also implemented in regions outside of Europe and North America. Other datasets such as AOD from AERONET, and various quality controlled satellite datasets may in the future become useful for trend analysis.

Chemical re-analyses are computationally expensive and time consuming, and cannot be easily performed for every new model version. However, an updated chemical reanalysis every couple of years, following major model and re-analysis product upgrades seems highly recommendable. These studies should preferentially be performed in close collaboration with other modeling groups, which allow sharing data and analysis methods. A better understanding of the chemical climate of the past is particularly relevant in the light of the continued effort to abate the negative impacts of air pollution, and the expected impacts of these controls on climate (Arneth et al., 2009; Raes and Seinfeld, 2009).

\section{Appendix A}

\section{ECHAM5-HAMMOZ: model description}

\section{A1 The ECHAM5 GCM}

ECHAM5 is a spectral GCM developed at the Max Planck Institute for Meteorology (Roeckner et al., 2003, 2006; Hagemann et al., 2006) based on the numerical weather prediction model of the European Centre for Medium-Range Weather Forecast (ECMWF). The prognostic variables of the model are vorticity, divergence, temperature, and surface pressure and are represented in the spectral space. The multidimensional flux-form semi-Lagrangian transport scheme from Lin and Rood (1996) is used for water vapor, cloud related variables, and chemical tracers. Stratiform clouds are described by a microphysical cloud scheme (Lohmann and Roeckner, 1996) with a prognostic statistical cloud cover scheme (Tompkins, 2002). Cumulus convection is parameterized with the mass flux scheme of Tiedtke (1989) with modifications from Nordeng (1994). The radiative transfer calculation considers vertical profiles of the greenhouse gases (e.g. $\mathrm{CO}_{2}, \mathrm{O}_{3}, \mathrm{CH}_{4}$ ), aerosols, as well as the cloud water and ice. The shortwave radiative transfer follows Cagnazzo et al. (2007) considering 6 spectral bands. For this part of the spectrum, cloud optical properties are calculated on the basis of Mie calculations using idealized size distributions for both cloud droplets and ice crystals (Rockel et al., 1991). The long-wave radiative transfer scheme is implemented according to Mlawer et al. (1997) and Morcrette et al. (1998) and considers 16 spectral bands. The cloud optical properties in the long-wave spectrum are parameterized as a function of the effective radius (Roeckner et al., 2003; Ebert and Curry, 1992). 


\section{A2 Gas-phase chemistry module MOZ}

The MOZ chemical scheme has been adopted from the MOZART-2 model (Horowitz et al., 2003), and includes 63 transported tracers and 168 reactions to represent the $\mathrm{NO}_{\mathrm{x}}-$ $\mathrm{HO}_{\mathrm{x}}$-hydrocarbons chemistry. The sulfur chemistry includes oxidation of $\mathrm{SO}_{2}$ by $\mathrm{OH}$ and DMS oxidation by $\mathrm{OH}$ and $\mathrm{NO}_{3}$ (Feichter et al., 1996). Stratospheric $\mathrm{O}_{3}$ concentrations are prescribed as monthly mean zonal climatology derived from observations (Logan, 1999; Randel et al., 1998). These concentrations are fixed at the topmost two model levels (pressures of $30 \mathrm{hPa}$ and above). At other model levels above the tropopause, the concentrations are relaxed towards these values with a relaxation time of 10 days following Horowitz et al. (2003). The photolysis frequencies are calculated with the algorithm Fast-J.2 (Bian and Prather, 2002) considering the calculated optical properties of aerosols and clouds. The rates of heterogeneous reactions involving $\mathrm{N}_{2} \mathrm{O}_{5}, \mathrm{NO}_{3}, \mathrm{NO}_{2}$, $\mathrm{HO}_{2}, \mathrm{SO}_{2} \mathrm{HNO}_{3}$, and $\mathrm{O}_{3}$ are calculated based on the model calculated aerosol surface area. A more detailed description of the tropospheric chemistry module $\mathrm{MOZ}$ and the coupling between the gas phase chemistry and the aerosols is given in Pozzoli et al. (2008a).

\section{A3 Aerosol module HAM}

The tropospheric aerosol module HAM (Stier et al., 2005) predicts the size distribution and composition of internallyand externally-mixed aerosol particles. The microphysical core of HAM, M7 (Vignati et al., 2004), treats the aerosol dynamics and thermodynamics in the framework of modal particle size distribution; the 7 log-normal modes are characterized by three moments including median radius, number of particles, and a fixed standard deviation (1.59 for fine particles and 2.00 for coarse particles. Four modes are considered as hydrophilic aerosols composed of sulfate (SU), organic (OC) and black carbon (BC), mineral dust (DU), and sea salt (SS): nucleation (NS) $(r \leq 0.005 \mu \mathrm{m})$, Aitken (KS) $(0.005 \mu \mathrm{m}<r \leq 0.05 \mu \mathrm{m})$, accumulation (AS) $(0.05 \mu \mathrm{m}<r \leq 0.5 \mu \mathrm{m})$ and coarse (CS) $(r>0.5 \mu \mathrm{m})$ (where $r$ is the number median radius). Note that in HAM the nucleation mode is entirely constituted of sulfate aerosols. Three additional modes are considered as hydrophobic aerosols composed of $\mathrm{BC}$ and $\mathrm{OC}$ in the Aitken mode (KI), and of mineral dust in the accumulation (AI) and coarse (CI) modes. Wavelength-dependent aerosol optical properties (single scattering albedo, extinction cross section, and asymmetry factor) were pre-calculated explicitly using Mie theory (Toon and Ackerman, 1981) and archived in a look-up-table for a wide range of aerosol size distributions and refractive indices. HAM is directly coupled to the cloud microphysics scheme, allowing consistent calculations of the aerosol indirect effects (Lohmann et al., 2007).

\section{A4 Gas and aerosol deposition}

Gas and aerosol dry deposition follows the scheme of Ganzeveld and Lelieveld (1995) and Ganzeveld et al. (1998, 2006), coupling the Wesely resistance approach with landcover data from ECHAM5. Wet deposition is based on Stier et al. (2005), including scavenging of aerosol particles by stratiform and convective clouds and below cloud scavenging. The scavenging parameters for aerosol particles are mode-specific with lower values for hydrophobic (externallymixed) modes. For gases, the partitioning between the air and the cloud water is calculated based on Henry's law and cloud water content.

\section{Appendix B}

\section{$\mathrm{O}_{3}$ and $\mathrm{SO}_{4}^{2-}$ measurement comparisons}

Figure B1 provides an example of the ECHAM5-HAMMOZ capabilities to reproduce surface $\mathrm{O}_{3}$ variability. We compared the observed and calculated monthly mean anomalies of surface $\mathrm{O}_{3}$ concentrations at 6 remote stations. Despite the fact that ECHAM5-HAMMOZ overestimates monthly mean $\mathrm{O}_{3}$ concentrations by up to $15 \mathrm{ppbv}$, and that the observed and calculated anomalies are not well correlated for all the considered stations, the model can capture the observed range of $\mathrm{O}_{3}$ variability at very different locations in the world. The anomalies at these remote stations are driven by the meteorological and natural emission variability, therefore it is hard to distinguish the effect of anthropogenic emissions comparing the SREF and SFIX simulations. In Europe, the variability at the stations of Mace Head and Hohenpeissenberg is well captured by the model, while lower agreement is found at Zingst. The observed $\mathrm{O}_{3}$ trend at Mace Head $\left(0.19 \mathrm{ppbv} \mathrm{yr}^{-1}\right)$ is not captured by the model $\left(-0.04 \mathrm{ppbv} \mathrm{yr}^{-1}\right)$, mainly because of the largest anomalies calculated in the 1990s. We obtained similar results also at Zingst. A better agreement is found at Hohenpeissenberg, 0.32 ppbv yr $^{-1}$ observed and $0.45 \mathrm{ppbv} \mathrm{yr}^{-1}$ calculated $\mathrm{O}_{3}$ trends. At Barrow (Alaska) and Mauna Loa (Hawaii), excluding the 1990 s, the variability is qualitatively well captured, while in the Southern Hemisphere, at Samoa, the variability is better captured in the 1980s.

Long measurement records of $\mathrm{O}_{3}$ and $\mathrm{SO}_{4}^{2-}$ are mainly available in Europe, North America, and at a few stations in East Asia from the following networks: the European Monitoring and Evaluation Programme (EMEP, http://www. emep.int/); the Clean Air Status and Trends Network (CASTNET, http://www.epa.gov/castnet/); the World Data Centre for Greenhouse Gases (WDCGG, http://gaw.kishou.go.jp/ wdcgg/). $\mathrm{O}_{3}$ measures are available starting from the year 1990 for EMEP, and at a few stations back to 1987 in the CASTNET and WDCGG networks. For this reason we selected only the stations that have at least $10 \mathrm{yr}$ records in the 

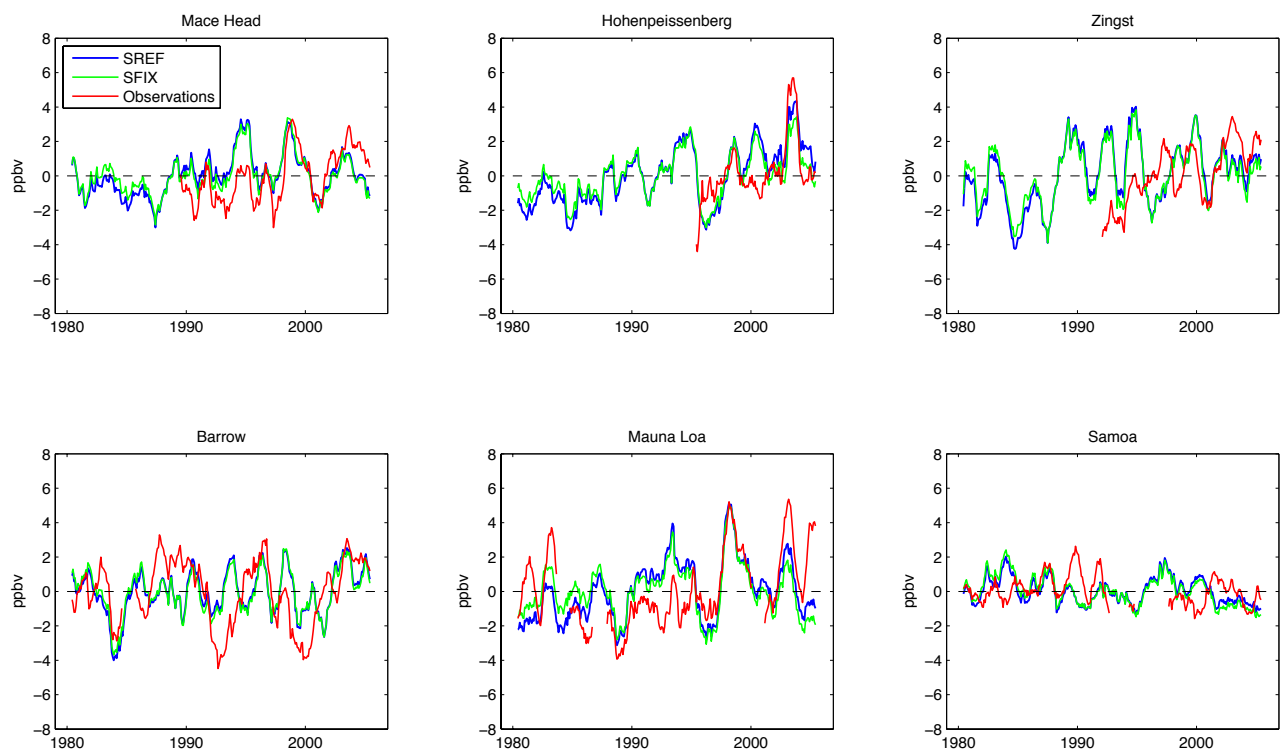

Fig. B1. Time evolution (1980-2005) of surface ozone monthly mean anomalies (12-month running mean) at a variety of remote sites. Observations are in red, ECHAM5-HAMMOZ results are in blue (SREF simulation) and green (SFIX simulation).

period 1990-2005 for both winter and summer. A total of 81 stations were selected over Europe from EMEP, 48 stations over North America from CASTNET, and 25 stations from WDCGG. The average record length among all selected stations is of 14 yr. For $\mathrm{SO}_{4}^{2-}$ measures, we selected 62 stations from EMEP, and 43 stations from CASTNET. The average record length among all selected stations is of $13 \mathrm{yr}$.

The location of each selected station is plotted in Fig. 1 for both $\mathrm{O}_{3}$ and $\mathrm{SO}_{4}^{2-}$ measurements. Each symbol represents a measuring network (EMEP: triangle; CASTNET: diamond; WDCGG: square) and each color a geographical subregion. Similarly to Fiore et al. (2009), we grouped stations in Central Europe (CEU, which includes mainly the stations of Germany, Austria, Switzerland, The Netherlands and Belgium), and Southern Europe (SEU, stations below $45^{\circ} \mathrm{N}$ and in the Mediterranean basin), but we also included in our study a group of stations for Northern Europe (NEU, which includes the Scandinavian countries), Eastern Europe (EEU, which includes stations east of $17^{\circ} \mathrm{E}$ ), Western Europe (WEU, UK and Ireland). Over North America we grouped the sites in 4 regions, Northeast (NEUS), Great Lakes (GLUS), MidAtlantic (MAUS) and Southwest (SUS), based on Lehman et al. (2004) representing chemically coherent receptor regions for $\mathrm{O}_{3}$ air pollution, and an additional region for Western US (WUS).

For each station we calculated the seasonal mean anomalies (DJF and JJA) by subtracting the multi-year average seasonal means from each annual seasonal mean. The same calculations were applied to the values extracted from ECHAM5-HAMMOZ SREF simulation, and the observed and calculated records were compared. The correlation coefficients between observed and calculated $\mathrm{O}_{3}$ DJF anomalies is larger than 0.5 for $44 \%, 39 \%$, and $36 \%$ of the selected EMEP, CASTNET, and WDCGG stations, respectively. The agreement $(R \geq 0.5)$ between observed and calculated $\mathrm{O}_{3}$ seasonal anomalies is improving in summer months, with $52 \%$ for EMEP, $66 \%$ for CASTNET, and $52 \%$ for WDCGG. For $\mathrm{SO}_{4}^{2-}$ the correlation between observed and calculated anomalies is larger than 0.5 for $56 \%$ (DJF) and $74 \%$ (JJA) of the EMEP selected stations. In $65 \%$ of the selected CASTNET stations the correlation between observed and calculated anomalies is larger than 0.5 , both in winter and summer.

The comparisons between model results and observations are synthesized in so-called Taylor diagrams, displaying the inter-annual correlation and normalized standard deviation (ratio between the standard deviations of the calculated values and of the observations). It can be shown that the distance of each point to the black dot $(1 ; 0)$ is a measure of the RMS error (Fig. B2). Winter (DJF) $\mathrm{O}_{3}$ inter-annual anomalies are relatively well represented by the model in Western Europe (WEU), Central Europe (CEU), and Northern Europe (NEU), with most correlation coefficients between 0.5-0.9, but generally underestimated standard deviations. A lower agreement $(R<0.5$; standard deviation $<0.5)$ is generally found for the stations in North America, except for the stations over GLUS and MAUS. These winter differences indicate that some drivers of wintertime anomalies (such as longrange transport- or stratosphere-troposphere exchange of $\mathrm{O}_{3}$ ) may not be sufficiently strongly included in the model. The summer (JJA) $\mathrm{O}_{3}$ anomalies are in general better represented by the model. The agreement of the modeled standard deviation with measurements is increasing compared to winter anomalies. A significant improvement compared to winter 

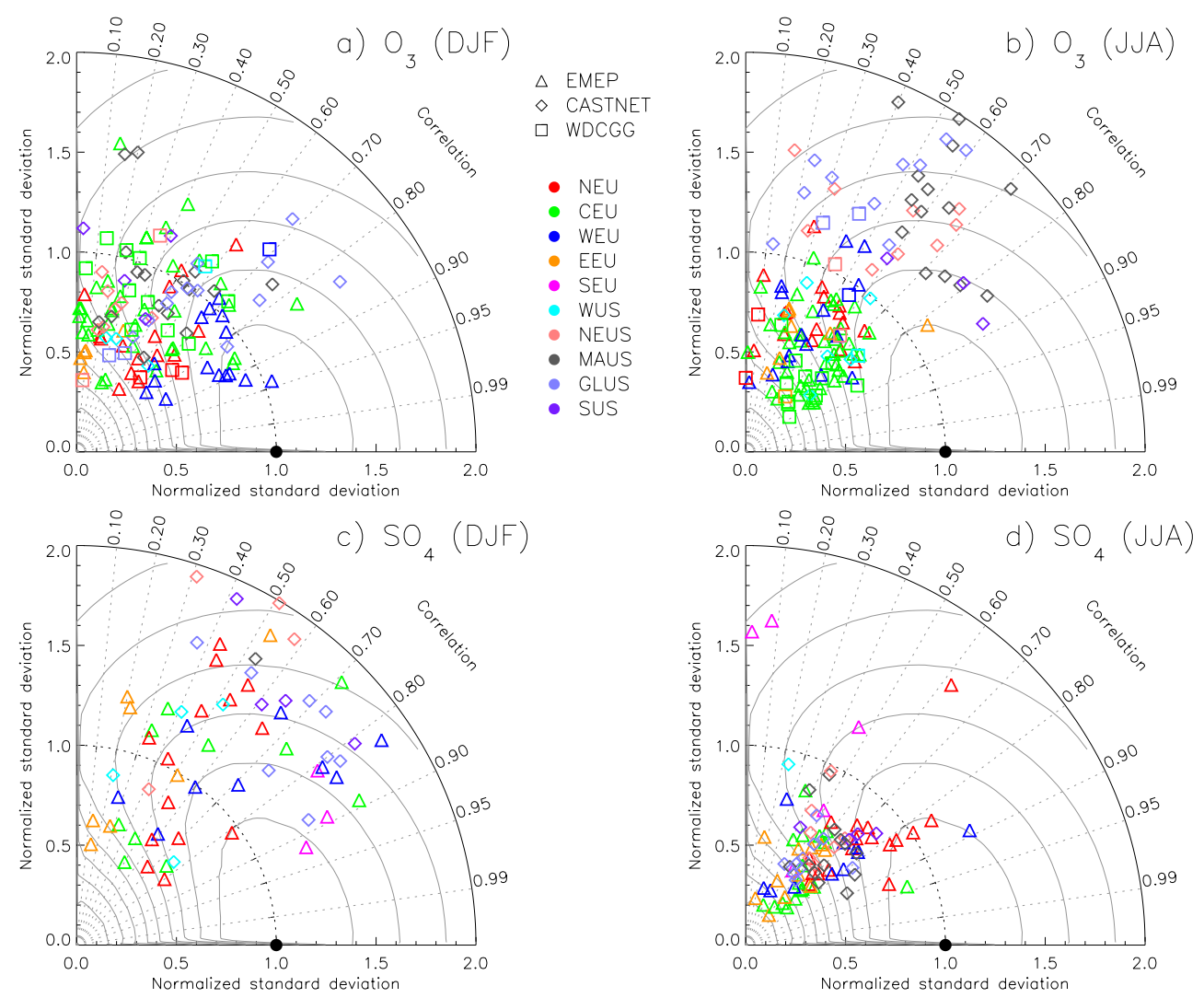

Fig. B2. Taylor diagrams comparing the ECHAM5-HAMMOZ SREF simulation with EMEP, CASTNET, and WDCGG observations of $\mathrm{O}_{3}$ seasonal means (a) DJF and (b) JJA) and $\mathrm{SO}_{4}^{2-}$ seasonal means (c) DJF and (d) JJA. The black dot is used as a reference to which simulated fields are compared. Continuous grey lines show iso-contours of skill score. Stations are grouped by regions as in Fig. 1: Northern Europe (NEU); Central Europe (CEU); Western Europe (WEU); Eastern Europe (EEU); Southern Europe (SEU); Western US (WUS): North-Eastern US (NEUS); Mid-Atlantic US (MAUS); Great lakes US (GLUS); Southern US (SUS).

anomalies is found over North American stations (SEUS, NEUS, and MAUS), while the CEU stations have low normalized standard deviation, even if correlation coefficients are above 0.6. Interestingly, while the European inter-annual variability of the summertime ozone remains underestimated (normalized standard deviation around 0.5) the opposite is true for North American variability, indicating a too large inter-annual variability of chemical $\mathrm{O}_{3}$ production, perhaps caused by too large contributions of natural $\mathrm{O}_{3}$ precursors. $\mathrm{SO}_{4}^{2-}$ winter anomalies are in general reasonably well captured in winter, with correlation $R>0.5$ at most stations, and the magnitude of the inter-annual variations. In general we found a much better agreement in summer than in winter between calculated and observed $\mathrm{SO}_{4}^{2-}$ variability, with interannual coefficients generally larger than 0.5 . In strong contrast with the winter season, now the inter-annual variability is always underestimated (normalized standard deviation of 0.3-0.9) indicating an underestimate in the model of chemical production variability, or removal efficiency. It is unlikely that anthropogenic emissions (the dominant emissions) variability was causing this lack of variability.
Tables B1 and B2 list the observed and calculated seasonal trends of $\mathrm{O}_{3}$ and $\mathrm{SO}_{4}^{2-}$ surface concentrations in the European and North American regions as defined before. In winter we found statistically significant increasing $\mathrm{O}_{3}$ trends (pvalue $<0.05$ ) in all European regions and in 3 North American regions (WUS, NEUS, and MAUS), see Table B1. The SREF model simulation could capture significant trends only over Central Europe (CEU) and Western Europe (WEU). We did not find significant trends for the SFIX simulation, which may indicate no $\mathrm{O}_{3}$ trends over Europe due to natural variability. In 2 North American regions we found significant decreasing trends (WUS and NEUS), in contrast with the observed increasing trends. We must note that in these 2 regions we also observed a decreasing trend due to natural variability $\left(T_{\mathrm{SFIX}}\right)$, which may be too strongly represented in our model. In summer, the observed decreasing $\mathrm{O}_{3}$ trends over Europe are not significant, while the calculated trends show a significant decrease $\left(T_{\mathrm{SREF}}\right.$ : NEU, WEU, and EEU), which is partially due to a natural trend ( $T_{\text {SFIX }}$ : NEU and EEU). In North America the observations show an increasing trend in WUS, and decreasing trends in all other 
Table B1. Observed and simulated trends of surface $\mathrm{O}_{3}$ seasonal anomalies for European (EU) and North American (NA) stations, grouped as in Fig. 1 (Northern Europe (NEU); Central Europe (CEU); Western Europe (WEU); Eastern Europe (EEU); Western US (WUS): NorthEastern US (NEUS); Mid-Atlantic US (MAUS); Great lakes US (GLUS); Southern US (SUS)). The number of stations (NSTA) for each regions is listed in the second column. The seasonal trends are listed separately for winter (DJF) and summer (JJA). Seasonal trends ( $\mathrm{ppbv} \mathrm{yr}^{-1}$ ) are calculated for observations ( $\left.T_{\mathrm{OBS}}\right)$, SREF and SFIX simulations ( $T_{\mathrm{SREF}}$ and $T_{\mathrm{SFIX}}$ ) as linear fitting of the median surface $\mathrm{O}_{3}$ anomalies of each group of stations (the $95 \%$ confidence interval is also shown for each calculated trend). The statistically significant trends (p-value $<0.05)$ are highlighted in bold. The correlation coefficient between median observed and simulated (SREF) anomalies are listed $\left(R_{\mathrm{OBS}} / \mathrm{SREF}\right)$. The statistically significant correlation coefficients (p-value $\left.<0.05\right)$ are highlighted in bold.

\begin{tabular}{|c|c|c|c|c|c|c|c|c|c|}
\hline \multicolumn{2}{|c|}{$\mathrm{O}_{3}$ Stations } & \multicolumn{4}{|c|}{ Winter anomalies (DJF) } & \multicolumn{4}{|c|}{ Summer anomalies (JJA) } \\
\hline REGION & NSTA & $T_{\mathrm{OBS}}$ & $T_{\mathrm{SREF}}$ & $T_{\text {SFIX }}$ & $R_{\mathrm{OBS} / \mathrm{SREF}}$ & $T_{\mathrm{OBS}}$ & $T_{\mathrm{SREF}}$ & $T_{\text {SFIX }}$ & $R_{\mathrm{OBS} / \mathrm{SREF}}$ \\
\hline NEU & 20 & $0.27 \pm 0.18$ & $0.05 \pm 0.23$ & $-0.08 \pm 0.26$ & 0.49 & $-0.00 \pm 0.22$ & $-0.44 \pm 0.26$ & $-0.29 \pm 0.27$ & 0.36 \\
\hline CEU & 54 & $\mathbf{0 . 4 4} \pm \mathbf{0 . 1 5}$ & $0.21 \pm 0.40$ & $0.06 \pm 0.40$ & 0.46 & $0.04 \pm 0.32$ & $-0.11 \pm 0.30$ & $-0.00 \pm 0.29$ & 0.73 \\
\hline WEU & 16 & $0.42 \pm 0.36$ & $0.40 \pm 0.55$ & $0.21 \pm 0.56$ & 0.93 & $-0.10 \pm 0.23$ & $-0.15 \pm 0.28$ & $-0.11 \pm 0.28$ & 0.62 \\
\hline EEU & 8 & $\mathbf{0 . 3 4} \pm \mathbf{0 . 3 8}$ & $0.06 \pm 0.27$ & $-0.09 \pm 0.28$ & 0.07 & $-0.02 \pm 0.25$ & $-0.36 \pm 0.36$ & $-0.22 \pm 0.34$ & 0.71 \\
\hline WUS & 7 & $0.12 \pm 0.21$ & $-\mathbf{0 . 0 8} \pm \mathbf{0 . 1 1}$ & $-0.12 \pm 0.12$ & 0.26 & $0.41 \pm 0.30$ & $0.11 \pm 0.21$ & $0.21 \pm 0.22$ & 0.80 \\
\hline NEUS & 11 & $0.22 \pm 0.13$ & $-\mathbf{0 . 1 0} \pm \mathbf{0 . 1 7}$ & $-0.17 \pm 0.15$ & 0.03 & $-0.27 \pm 0.28$ & $0.03 \pm 0.47$ & $0.14 \pm 0.49$ & 0.55 \\
\hline MAUS & 17 & $0.11 \pm 0.18$ & $-0.02 \pm 0.23$ & $-0.07 \pm 0.26$ & 0.66 & $-0.40 \pm 0.37$ & $0.09 \pm 0.81$ & $0.19 \pm 0.83$ & 0.68 \\
\hline GLUS & 14 & $0.04 \pm 0.18$ & $0.05 \pm 0.19$ & $-0.02 \pm 0.20$ & 0.82 & $-0.19 \pm 0.29$ & $0.20 \pm 0.47$ & $0.34 \pm 0.49$ & 0.43 \\
\hline SUS & 4 & $0.08 \pm 0.20$ & $-0.08 \pm 0.26$ & $-0.06 \pm 0.27$ & 0.50 & $-0.25 \pm 0.48$ & $0.29 \pm 0.84$ & $0.40 \pm 0.83$ & 0.64 \\
\hline
\end{tabular}

Table B2. Observed and simulated trends of surface $\mathrm{SO}_{4}^{2-}$ seasonal anomalies for European (EU) and North American (NA) stations, grouped as in Fig. 1 (Northern Europe (NEU); Central Europe (CEU); Western Europe (WEU); Eastern Europe (EEU); Southern Europe (SEU); Western US (WUS): North-Eastern US (NEUS); Mid-Atlantic US (MAUS); Great lakes US (GLUS); Southern US (SUS)). The number of stations (NSTA) for each regions is listed in the second column. The seasonal trends are listed separately for winter (DJF) and summer (JJA). Seasonal trends $\left(\mu \mathrm{g}(\mathrm{S}) \mathrm{m}^{-3} \mathrm{yr}^{-1}\right)$ are calculated for observations $\left(T_{\mathrm{OBS}}\right)$, SREF and SFIX simulations $\left(T_{\mathrm{SREF}}\right.$ and $\left.T_{\mathrm{SFIX}}\right)$ as linear fitting of the median surface $\mathrm{SO}_{4}^{2-}$ anomalies of each group of stations (the $95 \%$ confidence interval is also shown for each calculated trend). The statistically significant trends ( $\mathrm{p}$-value $<0.05)$ are highlighted in bold. The correlation coefficient between median observed and simulated $(\mathrm{SREF})$ anomalies are listed $\left(R_{\mathrm{OBS}} / \mathrm{SREF}\right)$. The statistically significant correlation coefficients $(\mathrm{p}$-value $<0.05)$ are highlighted in bold.

\begin{tabular}{|c|c|c|c|c|c|c|c|c|c|}
\hline \multicolumn{2}{|c|}{$\mathrm{SO}_{4}^{2-}$ Stations } & \multicolumn{4}{|c|}{ Winter anomalies (DJF) } & \multicolumn{4}{|c|}{ Summer anomalies (JJA) } \\
\hline REGION & NSTA & $T_{\mathrm{OBS}}$ & $T_{\mathrm{SREF}}$ & $T_{\text {SFIX }}$ & $R_{\mathrm{OBS} / \mathrm{SREF}}$ & $T_{\mathrm{OBS}}$ & $T_{\text {SREF }}$ & $T_{\text {SFIX }}$ & $R_{\mathrm{OBS} / \mathrm{SREF}}$ \\
\hline NEU & 18 & $-0.03 \pm 0.02$ & $-0.01 \pm 0.04$ & $0.02 \pm 0.08$ & 0.59 & $-0.03 \pm 0.01$ & $-\mathbf{0 . 0 3} \pm \mathbf{0 . 0 1}$ & $-\mathbf{0 . 0 1} \pm \mathbf{0 . 0 2}$ & 0.88 \\
\hline CEU & 18 & $-0.04 \pm 0.03$ & $-\mathbf{0 . 1 0} \pm \mathbf{0 . 0 8}$ & $-0.06 \pm 0.14$ & 0.67 & $-0.06 \pm 0.02$ & $-\mathbf{0 . 0 4} \pm \mathbf{0 . 0 2}$ & $0.00 \pm 0.02$ & 0.79 \\
\hline WEU & 10 & $-0.05 \pm \mathbf{0 . 0 3}$ & $-0.08 \pm 0.05$ & $-\mathbf{0 . 0 8} \pm \mathbf{0 . 1 0}$ & 0.83 & $-0.04 \pm 0.02$ & $-0.02 \pm 0.02$ & $0.01 \pm 0.03$ & 0.75 \\
\hline EEU & 11 & $-0.07 \pm 0.04$ & $-0.01 \pm 0.12$ & $0.05 \pm 0.18$ & 0.28 & $-\mathbf{0 . 0 8} \pm \mathbf{0 . 0 2}$ & $-0.04 \pm 0.02$ & $-0.01 \pm 0.02$ & 0.78 \\
\hline SEU & 5 & $-\mathbf{0 . 0 2} \pm \mathbf{0 . 0 2}$ & $-0.06 \pm 0.05$ & $-0.03 \pm 0.08$ & 0.78 & $-\mathbf{0 . 0 2} \pm \mathbf{0 . 0 2}$ & $-\mathbf{0 . 0 5} \pm \mathbf{0 . 0 2}$ & $-\mathbf{0 . 0 2} \pm \mathbf{0 . 0 3}$ & 0.75 \\
\hline WUS & 6 & $-\mathbf{0 . 0 0} \pm \mathbf{0 . 0 0}$ & $-\mathbf{0 . 0 1} \pm \mathbf{0 . 0 1}$ & $-0.00 \pm 0.01$ & 0.52 & $-0.00 \pm 0.00$ & $-0.00 \pm 0.01$ & $\mathbf{0 . 0 1} \pm \mathbf{0 . 0 1}$ & -0.11 \\
\hline NEUS & 9 & $-0.03 \pm 0.01$ & $-0.04 \pm 0.03$ & $-0.01 \pm 0.05$ & 0.29 & $-\mathbf{0 . 0 8} \pm \mathbf{0 . 0 3}$ & $-\mathbf{0 . 0 3} \pm \mathbf{0 . 0 2}$ & $\mathbf{0 . 0 2} \pm \mathbf{0 . 0 3}$ & 0.52 \\
\hline MAUS & 14 & $-0.02 \pm 0.01$ & $-0.06 \pm 0.02$ & $-0.02 \pm 0.04$ & 0.57 & $-0.08 \pm 0.03$ & $-0.04 \pm 0.02$ & $0.00 \pm 0.02$ & 0.73 \\
\hline GLUS & 10 & $-0.02 \pm 0.02$ & $-\mathbf{0 . 0 4} \pm \mathbf{0 . 0 3}$ & $-0.01 \pm 0.06$ & 0.11 & $-0.08 \pm 0.04$ & $-\mathbf{0 . 0 3} \pm \mathbf{0 . 0 2}$ & $0.01 \pm 0.02$ & 0.41 \\
\hline SUS & 4 & $-\mathbf{0 . 0 2} \pm \mathbf{0 . 0 2}$ & $-\mathbf{0 . 0 3} \pm \mathbf{0 . 0 2}$ & $-0.00 \pm 0.02$ & -0.05 & $-\mathbf{0 . 0 5} \pm \mathbf{0 . 0 4}$ & $-\mathbf{0 . 0 3} \pm \mathbf{0 . 0 3}$ & $0.00 \pm 0.04$ & 0.37 \\
\hline
\end{tabular}

regions. All the observed trends are statistically significant. The model could reproduce a significant positive trend only over WUS (which seems to be determined by natural variability, $T_{\text {SFIX }}>T_{\text {SREF }}$ ). In all other North American regions we found increasing trends, but not significant. Nevertheless the correlation coefficients between observed and simulated anomalies are better in summer and for both Europe and North America.
$\mathrm{SO}_{4}^{2-}$ trends are in general better represented by the model. Both in Europe and North America the observations show decreasing $\mathrm{SO}_{4}^{2-}$ trends (Table B2), both in winter and summer. The trends are statistically significant in all European and North American subregions, both in winter and summer. In North America (except WUS) the observed decreasing trends are slightly higher in summer (from -0.05 and $-0.08 \mu \mathrm{g}(\mathrm{S}) \mathrm{m}^{-3} \mathrm{yr}^{-1}$ ) than in winter (from -0.02 and 


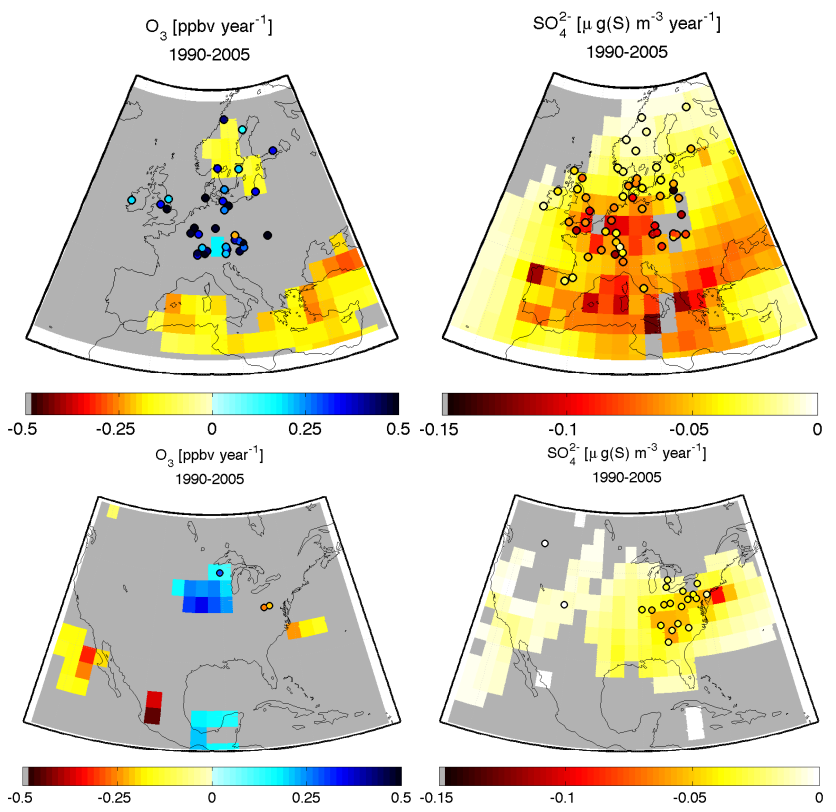

Fig. B3. Annual trends of $\mathrm{O}_{3}$ and $\mathrm{SO}_{4}^{2-}$ surface concentrations. The trends are calculated as linear fitting of the annual mean surface $\mathrm{O}_{3}$ and $\mathrm{SO}_{4}^{2-}$ anomalies for each grid box of the model simulation SREF over Europe and North America. The grid boxes with statistically not significant ( $\mathrm{p}$-value $>0.05$ ) trends are displayed in grey. The colored circles represent the observed trends for EMEP and CASTNET measuring stations, over Europe and North America, respectively. Only the stations with statistically significant ( $p$ value $<0.05$ ) trends are plotted.

$\left.-0.03 \mu \mathrm{g}(\mathrm{S}) \mathrm{m}^{-3} \mathrm{yr}^{-1}\right)$. The calculated trends $\left(T_{\mathrm{SREF}}\right)$ are in general overestimated in winter and underestimated in summer. We must note that a seasonality in anthropogenic sulfur emissions was introduced only over Europe (30\% higher in winter and $30 \%$ lower in summer compared to annual mean), while in the rest of the world, annual mean sulfur emissions were provided.

In Fig. B3 we show a comparison between the observed and calculated (SREF) annual trends of $\mathrm{O}_{3}$ and $\mathrm{SO}_{4}^{2-}$ for the European (EMEP) and the North American (CASTNET) measuring stations. The grey areas represent the grid boxes of the model where trends are not statistically significant. We also excluded from the plot the stations where trends are not significant. Over Europe the observed $\mathrm{O}_{3}$ annual trends are increasing, while the model does not show a significant $\mathrm{O}_{3}$ trend for almost all of Europe. In the model statistically significant decreasing trends are found over the Mediterranean and in part of Scandinavia and the Baltic Sea. In North America both the observed and modeled trends are mainly not statistically significant. Decreasing $\mathrm{SO}_{4}^{2-}$ annual trends are found over Europe and North America, with a general good agreement between the observations from single stations and the model results.
Acknowledgements. This work has received partial funding from the European Community's Seventh Framework Programme (FP7) in the project PEGASOS (grant agreement 265148). We greatly acknowledge Sebastian Rast at Max Planck Institute for Meteorology, Hamburg, for the scientific and technical support. We would like also to thank the Deutsches Klimarechenzentrum (DKRZ) and the Forschungszentrum Jülich for the computing resources and technical support. We would like to thank the EMEP, WDCGG, and CASTNET networks for providing ozone and sulfate measurements over Europe and North America.

Edited by: Y. Balkanski

\section{References}

Andres, R. and Kasgnoc, A.: A time-averaged inventory of subaerial volcanic sulfur emissions, J. Geophys. Res.-Atmos., 103, 25251-25261, 1998.

Arneth, A., Unger, N., Kulmala, M., and Andreae, M. O.: Clean the Air, Heat the Planet?, Science, 326, 672-673, http://www. sciencemag.org/content/326/5953/672.short, 2009.

Auvray, M., Bey, I., Llull, E., Schultz, M. G., and Rast, S.: A model investigation of tropospheric ozone chemical tendencies in long-range transported pollution plumes, J. Geophys. Res., 112, D05304, doi:10.1029/2006JD007137, 2007.

Berglen, T., Myhre, G., Isaksen, I., Vestreng, V., and Smith, S.: Sulphate trends in Europe: Are we able to model the recent observed decrease?, Tellus B, 59, 773-786, http://www.scopus. com/inward/record.url?eid=2-s2.0-3454791924\% $7 \&$ partnerID= 40\&md5=b70fa1dd6e13861b2282403bf2239728, 2007.

Bian, H. and Prather, M.: Fast-J2: Accurate simulation of stratospheric photolysis in global chemical models, J. Atmos. Chem., 41, 281-296, 2002.

Bond, T. C., Streets, D. G., Yarber, K. F., Nelson, S. M., Woo, J.H., and Klimont, Z.: A technology-based global inventory of black and organic carbon emissions from combustion, J. Geophys. Res., 109, D14203, doi:10.1029/2003JD003697, 2004.

Cagnazzo, C., Manzini, E., Giorgetta, M. A., Forster, P. M. De F., and Morcrette, J. J.: Impact of an improved shortwave radiation scheme in the MAECHAM5 General Circulation Model, Atmos. Chem. Phys., 7, 2503-2515, doi:10.5194/acp-7-2503-2007, 2007.

Chan, E. and Vet, R. J.: Baseline levels and trends of ground level ozone in Canada and the United States, Atmos. Chem. Phys., 10, 8629-8647, doi:10.5194/acp-10-8629-2010, 2010.

Cheng, T., Peng, Y., Feichter, J., and Tegen, I.: An improvement on the dust emission scheme in the global aerosol-climate model ECHAM5-HAM, Atmos. Chem. Phys., 8, 1105-1117, doi:10.5194/acp-8-1105-2008, 2008.

Collins, W. D., Bitz, C. M., Blackmon, M. L., Bonan, G. B., Bretherton, C. S., Carton, J. A., Chang, P., Doney, S. C., Hack, J. J., Henderson, T. B., Kiehl, J. T., Large, W. G., McKenna, D. S., Santer, B. D., and Smith, R. D.: The Community Climate System Model Version 3 (CCSM3), J. Climate, 19, 2122-2143, doi:10.1175/JCLI3761.1, 2006.

Cui, J., Pandey Deolal, S., Sprenger, M., Henne, S., Staehelin, J., Steinbacher, M., and Nédélec, P.: Free tropospheric ozone changes over Europe as observed at Jungfraujoch (19902008): 
An analysis based on backward trajectories, J. Geophys. Res., 116, D10304, doi:10.1029/2010JD015154, 2011.

Dentener, F., Peters, W., Krol, M., van Weele, M., Bergamaschi, P., and Lelieveld, J.: Interannual variability and trend of $\mathrm{CH}_{4}$ lifetime as a measure for $\mathrm{OH}$ changes in the 1979-1993 time period, J. Geophys. Res.-Atmos., 108, 4442, doi:10.1029/2002JD002916, 2003.

Dentener, F., Kinne, S., Bond, T., Boucher, O., Cofala, J., Generoso, S., Ginoux, P., Gong, S., Hoelzemann, J. J., Ito, A., Marelli, L., Penner, J. E., Putaud, J.-P., Textor, C., Schulz, M., van der Werf, G. R., and Wilson, J.: Emissions of primary aerosol and precursor gases in the years 2000 and 1750 prescribed data-sets for AeroCom, Atmos. Chem. Phys., 6, 4321-4344, doi:10.5194/acp6-4321-2006, 2006.

Ebert, E. and Curry, J.: A parameterization of ice-cloud optical properties for climate models, J. Geophys. Res.-Atmos., 97, 3831-3836, 1992.

Ellingsen, K., Gauss, M., van Dingenen, R., Dentener, F. J., Emberson, L., Fiore, A. M., Schultz, M. G., Stevenson, D. S., Ashmore, M. R., Atherton, C. S., Bergmann, D. J., Bey, I., Butler, T., Drevet, J., Eskes, H., Hauglustaine, D. A., Isaksen, I. S. A., Horowitz, L. W., Krol, M., Lamarque, J. F., Lawrence, M. G., van Noije, T., Pyle, J., Rast, S., Rodriguez, J., Savage, N., Strahan, S., Sudo, K., Szopa, S., and Wild, O.: Global ozone and air quality: a multi-model assessment of risks to human health and crops, Atmos. Chem. Phys. Discuss., 8, 2163-2223, doi:10.5194/acpd8-2163-2008, 2008.

Endresen, A., Sorgard, E., Sundet, J. K., Dalsoren, S. B., Isaksen, I. S. A., Berglen, T. F., and Gravir, G.: Emission from international sea transportation and environmental impact, J. Geophys. Res., 108, 4560, doi:10.1029/2002JD002898, 2003.

Eyring, V., Köhler, H. W., van Aardenne, J., and Lauer, A.: Emissions from international shipping: 1 . The last 50 years, J. Geophys. Res., 110, D17305, doi:10.1029/2004JD005619, 2005.

Eyring, V., Köhler, H. W., Lauer, A., and Lemper, B.: Emissions from international shipping: 2. Impact of future technologies on scenarios until 2050, J. Geophys. Res., 110, D17306, doi:10.1029/2004JD005620, 2005.

Feichter, J., Kjellstrom, E., Rodhe, H., Dentener, F., Lelieveld, J., and Roelofs, G.: Simulation of the tropospheric sulfur cycle in a global climate model, Atmos. Environ., 30, 1693-1707, 1996.

Fiore, A., Horowitz, L., Dlugokencky, E., and West, J.: Impact of meteorology and emissions on methane trends, 1990-2004, Geophys. Res. Lett., 33, L12809, doi:10.1029/2006GL026199, 2006.

Fiore, A. M., Dentener, F. J., Wild, O., Cuvelier, C., Schultz, M. G., Hess, P., Textor, C., Schulz, M., Doherty, R. M., Horowitz, L. W., MacKenzie, I. A., Sanderson, M. G., Shindell, D. T., Stevenson, D. S., Szopa, S., van Dingenen, R., Zeng, G., Atherton, C., Bergmann, D., Bey, I., Carmichael, G., Collins, W. J., Duncan, B. N., Faluvegi, G., Folberth, G., Gauss, M., Gong, S., Hauglustaine, D., Holloway, T., Isaksen, I. S. A., Jacob, D. J., Jonson, J. E., Kaminski, J. W., Keating, T. J., Lupu, A., Marmer, E., Montanaro, V., Park, R. J., Pitari, G., Pringle, K. J., Pyle, J. A., Schroeder, S., Vivanco, M. G., Wind, P., Wojcik, G., Wu, S., and Zuber, A.: Multimodel estimates of intercontinental sourcereceptor relationships for ozone pollution, J. Geophys. Res., 114, D04301, doi:10.1029/2008JD010816, 2009.

Ganzeveld, L. and Lelieveld, J.: Dry deposition parameterization in a chemistry general circulation model and its influence on the distribution of reactive trace gases, J. Geophys. Res.-Atmos., 100, 20999-21012, 1995.

Ganzeveld, L., Lelieveld, J., and Roelofs, G.: A dry deposition parameterization for sulfur oxides in a chemistry and general circulation model, J. Geophys. Res.-Atmos., 103, 5679-5694, 1998.

Ganzeveld, L. N., van Aardenne, J. A., Butler, T. M., Lawrence, M. G., Metzger, S. M., Stier, P., Zimmermann, P., and Lelieveld, J.: Technical Note: Anthropogenic and natural offline emissions and the online EMissions and dry DEPosition submodel EMDEP of the Modular Earth Submodel system (MESSy), Atmos. Chem. Phys. Discuss., 6, 5457-5483, doi:10.5194/acpd-6-5457-2006, 2006.

Gauss, M., Myhre, G., Isaksen, I. S. A., Grewe, V., Pitari, G., Wild, O., Collins, W. J., Dentener, F. J., Ellingsen, K., Gohar, L. K., Hauglustaine, D. A., Iachetti, D., Lamarque, F., Mancini, E., Mickley, L. J., Prather, M. J., Pyle, J. A., Sanderson, M. G., Shine, K. P., Stevenson, D. S., Sudo, K., Szopa, S., and Zeng, G.: Radiative forcing since preindustrial times due to ozone change in the troposphere and the lower stratosphere, Atmos. Chem. Phys., 6, 575-599, doi:10.5194/acp-6-575-2006, 2006.

Grewe, V., Brunner, D., Dameris, M., Grenfell, J. L., Hein, R., Shindell, D., and Staehelin, J.: Origin and variability of upper tropospheric nitrogen oxides and ozone at northern mid-latitudes, Atmos. Environ., 35, 3421-3433, 2001.

Guenther, A., Hewitt, C., Erickson, D., Fall, R., Geron, C., Graedel, T., Harley, P., Klinger, L., Lerdau, M., McKay, W., Pierce, T., Scholes, B., Steinbrecher, R., Tallamraju, R., Taylor, J., and Zimmerman, P.: A global-model of natural volatile organiccompound emissions, J. Geophys. Res.-Atmos., 100, 88738892, 1995.

Guenther, A., Karl, T., Harley, P., Wiedinmyer, C., Palmer, P. I., and Geron, C.: Estimates of global terrestrial isoprene emissions using MEGAN (Model of Emissions of Gases and Aerosols from Nature), Atmos. Chem. Phys., 6, 3181-3210, doi:10.5194/acp-63181-2006, 2006.

Hagemann, S., Arpe, K., and Roeckner, E.: Evaluation of the Hydrological Cycle in the ECHAM5 Model, J. Climate, 19, 38103827, 2006.

Halmer, M., Schmincke, H., and Graf, H.: The annual volcanic gas input into the atmosphere, in particular into the stratosphere: a global data set for the past 100 years, J. Volcanol. Geothermal Res., 115, 511-528, 2002.

Hess, P. and Mahowald, N.: Interannual variability in hindcasts of atmospheric chemistry: the role of meteorology, Atmos. Chem. Phys., 9, 5261-5280, doi:10.5194/acp-9-5261-2009, 2009.

Horowitz, L., Walters, S., Mauzerall, D., Emmons, L., Rasch, P., Granier, C., Tie, X., Lamarque, J., Schultz, M., Tyndall, G., Orlando, J., and Brasseur, G.: A global simulation of tropospheric ozone and related tracers: Description and evaluation of MOZART, version 2, J. Geophys. Res.-Atmos., 108, 4784, doi:10.1029/2002JD002853, 2003.

Jaffe, D. and Ray, J.: Increase in surface ozone at rural sites in the western US, Atmos. Env., 41, 54525463, ISSN 1352-2310, doi:10.1016/j.atmosenv.2007.02.034, 2007.

Jeuken, A., Siegmund, P., Heijboer, L., Feichter, J., and Bengtsson, L.: On the potential of assimilating meteorological analyses in a global climate model for the purpose of model validation, J. Geophys. Res.-Atmos., 101, 16939-16950, 1996.

Jonson, J. E., Simpson, D., Fagerli, H., and Solberg, S.: Can we ex- 
plain the trends in European ozone levels?, Atmos. Chem. Phys., 6, 51-66, doi:10.5194/acp-6-51-2006, 2006.

Kettle, A. and Andreae, M.: Flux of dimethylsulfide from the oceans: A comparison of updated data seas and flux models, J. Geophys. Res.-Atmos., 105, 26793-26808, 2000.

Kinne, S., Schulz, M., Textor, C., Guibert, S., Balkanski, Y., Bauer, S. E., Berntsen, T., Berglen, T. F., Boucher, O., Chin, M., Collins, W., Dentener, F., Diehl, T., Easter, R., Feichter, J., Fillmore, D., Ghan, S., Ginoux, P., Gong, S., Grini, A., Hendricks, J., Herzog, M., Horowitz, L., Isaksen, I., Iversen, T., Kirkevåg, A., Kloster, S., Koch, D., Kristjansson, J. E., Krol, M., Lauer, A., Lamarque, J. F., Lesins, G., Liu, X., Lohmann, U., Montanaro, V., Myhre, G., Penner, J., Pitari, G., Reddy, S., Seland, O., Stier, P., Takemura, T., and Tie, X.: An AeroCom initial assessment - optical properties in aerosol component modules of global models, Atmos. Chem. Phys., 6, 1815-1834, doi:10.5194/acp-6-1815-2006, 2006.

Klimont, Z., Cofala, J., Xing, J., Wei, W., Zhang, C., Wang, S., Kejun, J., Bhandari, P., Mathura, R., Purohit, P., Rafaj, P., Chambers, A., Amann, M., and Hao, J.: Projections of SO2, NOx, and carbonaceous aerosols emissions in Asia, Tellus, 61B, 602-617, doi:10.1111/j.1600-0889.2009.00428.x, 2009.

Lamarque, J.-F., Bond, T. C., Eyring, V., Granier, C., Heil, A., Klimont, Z., Lee, D., Liousse, C., Mieville, A., Owen, B., Schultz, M. G., Shindell, D., Smith, S. J., Stehfest, E., van Aardenne, J., Cooper, O. R., Kainuma, M., Mahowald, N., McConnell, J. R., Naik, V., Riahi, K., and van Vuuren, D. P.: Historical (1850-2000) gridded anthropogenic and biomass burning emissions of reactive gases and aerosols: methodology and application, Atmos. Chem. Phys., 10, 7017-7039, doi:10.5194/acp10-7017-2010, 2010.

Lathière, J., Hauglustaine, D. A., Friend, A. D., De NobletDucoudré, N., Viovy, N., and Folberth, G. A.: Impact of climate variability and land use changes on global biogenic volatile organic compound emissions, Atmos. Chem. Phys., 6, 2129-2146, doi:10.5194/acp-6-2129-2006, 2006.

Lawrence, M. G., Jöckel, P., and von Kuhlmann, R.: What does the global mean $\mathrm{OH}$ concentration tell us?, Atmos. Chem. Phys., 1, 37-49, doi:10.5194/acp-1-37-2001, 2001.

Lehman, J., Swinton, K., Bortnick, S., Hamilton, C., Baldridge, E., Eder, B., and Cox, B.: Spatio-temporal characterization of tropospheric ozone across the eastern United States, Atmos. Environ., 38, 4357-4369, 2004.

Lin, S. and Rood, R.: Multidimensional flux-form semi-Lagrangian transport schemes, Mon. Weather Rev., 124, 2046-2070, 1996.

Logan, J.: An analysis of ozonesonde data for the troposphere: Recommendations for testing 3-D models and development of a gridded climatology for tropospheric ozone, J. Geophys. Res.Atmos., 104, 16115-16149, 1999.

Lohmann, U. and Roeckner, E.: Design and performance of a new cloud microphysics scheme developed for the ECHAM general circulation model, Climate Dynamics, 12, 557-572, 1996.

Lohmann, U., Stier, P., Hoose, C., Ferrachat, S., Kloster, S., Roeckner, E., and Zhang, J.: Cloud microphysics and aerosol indirect effects in the global climate model ECHAM5-HAM, Atmos. Chem. Phys., 7, 3425-3446, doi:10.5194/acp-7-3425-2007, 2007.

Mlawer, E., Taubman, S., Brown, P., Iacono, M., and Clough, S.: Radiative transfer for inhomogeneous atmospheres: RRTM, a validated correlated-k model for the longwave, J. Geophys. Res.Atmos., 102, 16663-16682, 1997.

Montzka, S. A., Krol, M., Dlugokencky, E., Hall, B., Jockel, P., and Lelieveld, J.: Small Interannual Variability of Global Atmospheric Hydroxyl, Science, 331, 67-69, http://www.sciencemag. org/content/331/6013/67.abstract, 2011.

Morcrette, J., Clough, S., Mlawer, E., and Iacono, M.: Imapct of a validated radiative transfer scheme, RRTM, on the ECMWF model climate and 10-day forecasts, Tech. Rep. 252, ECMWF, Reading, UK, 1998.

Nakicenovic, N., Alcamo, J., Davis, G., de Vries, H., Fenhann, J., Gaffin, S., Gregory, K., Grubler, A., Jung, T., Kram, T., Rovere, E. L., Michaelis, L., Mori, S., Morita, T., Papper, W., Pitcher, H., Price, L., Riahi, K., Roehrl, A., Rogner, H.-H., Sankovski, A., Schlesinger, M., Shukla, P., Smith, S., Swart, R., van Rooijen, S., Victor, N., and Dadi., Z.: Special Report on Emissions Scenarios. Intergovernmental Panel on Climate Change, Cambridge University Press, Cambridge, 2000.

Nightingale, P., Malin, G., Law, C., Watson, A., Liss, P., Liddicoat, M., Boutin, J., and Upstill-Goddard, R.: In situ evaluation of airsea gas exchange parameterizations using novel conservative and volatile tracers, Global Biogeochem. Cy., 14, 373-387, 2000.

Nordeng, T.: Extended versions of the convective parameterization scheme at ECMWF and their impact on the mean and transient activity of the model in the tropics, Tech. Rep. 206, ECMWF, Reading, UK, 1994.

Oltmans, S. J., Lefohn, A. S., Harris, J. M., and Shadwick D.: Background ozone levels of air entering the west coast of the U.S. and assessment of longer-term changes, Atmos. Environ., 42, 60206038, 2008.

Parrish, D. D., Millet, D. B., and Goldstein, A. H.: Increasing ozone in marine boundary layer inflow at the west coasts of North America and Europe, Atmos. Chem. Phys., 9, 1303-1323, doi:10.5194/acp-9-1303-2009, 2009.

Pham, M., Muller, J., Brasseur, G., Granier, C., and Megie, G.: A three-dimensional study of the tropospheric sulfur cycle, J. Geophys. Res.-Atmos., 100, 26061-26092, 1995.

Pozzoli, L., Bey, I., Rast, S., Schultz, M. G., Stier, P., and Feichter, J.: Trace gas and aerosol interactions in the fully coupled model of aerosol-chemistry-climate ECHAM5HAMMOZ: 1. Model description and insights from the spring 2001 TRACE-P experiment, J. Geophys. Res., 113, D07308, doi:10.1029/2007JD009007, 2008a.

Pozzoli, L., Bey, I., Rast, S., Schultz, M. G., Stier, P., and Feichter, J.: Trace gas and aerosol interactions in the fully coupled model of aerosol-chemistry-climate ECHAM5-HAMMOZ: 2. Impact of heterogeneous chemistry on the global aerosol distributions, J. Geophys. Res., 113, D07309, doi:10.1029/2007JD009008, 2008 b.

Prinn, R. G., Huang, J., Weiss, R. F., Cunnold, D. M., Fraser, P. J., Simmonds, P. G., McCulloch, A., Harth, C., Reimann, S., Salameh, P., O’Doherty, S., Wang, R. H. J., Porter, L. W., Miller, B. R., and Krummel, P. B.: Evidence for variability of atmospheric hydroxyl radicals over the past quarter century, Geophys. Res. Lett., 32, L07809, doi:10.1029/2004GL022228, 2005.

Raes, F. and Seinfeld, J.: Climate Change and Air Pollution Abatement: A Bumpy Road., Atmos. Environ., 43, 5132-5133, 2009.

Randel, W., Wu, F., Russell, J., Roche, A., and Waters, J.: Seasonal cycles and $\mathrm{QBO}$ variations in stratospheric $\mathrm{CH}_{4}$ and $\mathrm{H}_{2} \mathrm{O}$ 
observed in UARS HALOE data, J. Atmos. Sci., 55, 163-185, 1998.

Rast, J., Schultz, M., Aghedo, A., Bey, I., Brasseur, G., Diehl, T., Esch, M., Ganzeveld, L., Kirchner, I., Kornblueh, L., Rhodin, A., Roeckner, E., Schmidt, H., Schroede, S., Schulzweida, U., Stier, P., and van Noije, T.: Evaluation of the tropospheric chemistry general circulation model ECHAM5-MOZ and its application to the analysis of the inter-annual variability in tropospheric ozone from 1960-2000 chemical composition of the troposphere for the period 1960-2000 (RETRO), MPI-Report (Reports on Earth System Science), 2011.

Richter, A., Burrows, J. P., Nuss, H., Granier, C., and Niemeier, U.: Increase in tropospheric nitrogen dioxide over China observed from space, Nature, 437(7055), 129-132, 2005.

Rockel, B., Raschke, E., and Weyres, B.: A parameterization of broad band radiative transfer properties of water, ice and mixed clouds, Beitr. Phys. Atmos., 64, 1-12, 1991.

Roeckner, E., Bauml, G., Bonaventura, L., Brokopf, R., Esch, M., Giorgetta, M., Hagemann, S., Kirchner, I., Kornblueh, L., Manzini, E., Rhodin, A., Schlese, U., Schulzweida, U., and Tompkins, A.: The atmospehric general circulation model ECHAM5: Part 1, Tech. Rep. 349, Max Planck Institute for Meteorology, Hamburg, 2003.

Roeckner, E., Brokopf, R., Esch, M., Giorgetta, M., Hagemann, S., Kornblueh, L., Manzini, E., Schlese, U., and Schulzweida, U.: Sensitivity of Simulated Climate to Horizontal and Vertical Resolution in the ECHAM5 Atmosphere Model, J. Climate, 19, 3771-3791, 2006.

Schultz, M., Backman, L., Balkanski, Y., Bjoerndalsaeter, S., Brand, R., Burrows, J., Dalsoeren, S., de Vasconcelos, M., Grodtmann, B., Hauglustaine, D., Heil, A., Hoelzemann, J., Isaksen, I., Kaurola, J., Knorr, W., Ladstaetter-Weienmayer, A., Mota, B., Oom, D., Pacyna, J., Panasiuk, D., Pereira, J., Pulles, T., Pyle, J., Rast, S., Richter, A., Savage, N., Schnadt, C., Schulz, M., Spessa, A., Staehelin, J., Sundet, J., Szopa, S., Thonicke, K., van het Bolscher, M., van Noije, T., van Velthoven, P., Vik, A., and Wittrock, F.: REanalysis of the TROpospheric chemical composition over the past 40 years (RETRO). A long-term global modeling study of tropospheric chemistry. Final Report, Tech. rep., Max Planck Institute for Meteorology, Hamburg, Germany, 2007

Schultz, M. G., Heil, A., Hoelzemann, J. J., Spessa, A., Thonicke, K., Goldammer, J. G., Held, A. C., Pereira, J. M. C., and van het Bolscher, M.: Global wildland fire emissions from 1960 to 2000, Global Biogeochem. Cy., 22, GB2002, doi:10.1029/2007GB003031, 2008.

Schulz, M., de Leeuw, G., and Balkanski, Y.: Emission Of Atmospheric Trace Compounds, chap. Sea-salt aerosol source functions and emissions, 333-359, Kluwer, 2004.

Schumann, U. and Huntrieser, H.: The global lightning-induced nitrogen oxides source, Atmos. Chem. Phys., 7, 3823-3907, doi:10.5194/acp-7-3823-2007, 2007.

Solberg, S., Hov, O., Sovde, A., Isaksen, I. S. A., Coddeville, P., De Backer, H., Forster, C., Orsolini, Y., and Uhse, K.: European surface ozone in the extreme summer 2003, J. Geophys. Res., 113, D07307, doi:10.1029/2007JD009098, 2008.

Solomon, S., Qin, D., Manning, M., Chen, Z., Marquis, M., Averyt, K., Tignor, M., and Miller, H. L.: Contribution of Working Group I to the Fourth Assessment Report of the Intergovernmen- tal Panel on Climate Change, 2007, Cambridge University Press, Cambridge, United Kingdom and New York, NY, USA, 2007.

Stevenson, D., Dentener, F., Schultz, M., Ellingsen, K., van Noije, T., Wild, O., Zeng, G., Amann, M., Atherton, C., Bell, N., Bergmann, D., Bey, I., Butler, T., Cofala, J., Collins, W., Derwent, R., Doherty, R., Drevet, J., Eskes, H., Fiore, A., Gauss, M., Hauglustaine, D., Horowitz, L., Isaksen, I., Krol, M., Lamarque, J., Lawrence, M., Montanaro, V., Muller, J., Pitari, G., Prather, M., Pyle, J., Rast, S., Rodriguez, J., Sanderson, M., Savage, N., Shindell, D., Strahan, S., Sudo, K., and Szopa, S.: Multimodel ensemble simulations of present-day and near-future tropospheric ozone, J. Geophys. Res.-Atmos., 111, D08301, doi:10.1029/2005JD006338, 2006.

Stier, P., Feichter, J., Kinne, S., Kloster, S., Vignati, E., Wilson, J., Ganzeveld, L., Tegen, I., Werner, M., Balkanski, Y., Schulz, M., Boucher, O., Minikin, A., and Petzold, A.: The aerosolclimate model ECHAM5-HAM, Atmos. Chem. Phys., 5, 1125 1156, doi:10.5194/acp-5-1125-2005, 2005.

Stier, P., Seinfeld, J. H., Kinne, S., and Boucher, O.: Aerosol absorption and radiative forcing, Atmos. Chem. Phys., 7, 52375261, doi:10.5194/acp-7-5237-2007, 2007.

Streets, D. G., Bond, T. C., Lee, T., and Jang, C.: On the future of carbonaceous aerosol emissions, J. Geophys. Res., 109, D24212, doi:10.1029/2004JD004902, 2004.

Streets, D. G., Wu, Y., and Chin, M.: Two-decadal aerosol trends as a likely explanation of the global dimming/brightening transition, Geophys. Res. Lett., 33, L15806, doi:10.1029/2006GL026471, 2006.

Streets, D. G., Yan, F., Chin, M., Diehl, T., Mahowald, N., Schultz, M., Wild, M., Wu, Y., and Yu, C.: Anthropogenic and natural contributions to regional trends in aerosol optical depth, 1980-2006, J. Geophys. Res., 114, D00D18, doi:10.1029/2008JD011624, 2009.

Taylor, K.: Summarizing multiple aspects of model performance in a single diagram, J. Geophys. Res.-Atmos., 106, 7183-7192, 2001.

Tegen, I., Harrison, S., Kohfeld, K., Prentice, I., Coe, M., and Heimann, M.: Impact of vegetation and preferential source areas on global dust aerosol: Results from a model study, J. Geophys. Res.-Atmos., 107, 4576, doi:10.1029/2001JD000963, 2002.

Tiedtke, M.: A comprehensive mass flux scheme for cumulus parameterization in large-scale models, Mon. Weather Rev., 117, 1779-1800, 1989.

Tompkins, A.: A prognostic parameterization for the subgrid-scale variability of water vapor and clouds in large-scale models and its use to diagnose cloud cover, J. Atmos. Sci., 59, 1917-1942, 2002.

Toon, O. and Ackerman, T.: Algorithms for the calculation of scattering by stratified spheres, Appl. Optics, 20, 3657-3660, 1981.

Tost, H., Jöckel, P., and Lelieveld, J.: Lightning and convection parameterisations - uncertainties in global modelling, Atmos. Chem. Phys., 7, 4553-4568, doi:10.5194/acp-7-4553-2007, 2007.

Tressol, M., Ordonez, C., Zbinden, R., Brioude, J., Thouret, V., Mari, C., Nedelec, P., Cammas, J.-P., Smit, H., Patz, H.-W., and Volz-Thomas, A.: Air pollution during the 2003 European heat wave as seen by MOZAIC airliners, Atmos. Chem. Phys., 8, 2133-2150, doi:10.5194/acp-8-2133-2008, 2008.

Unger, N., Menon, S., Koch, D. M., and Shindell, D. T.: Im- 
pacts of aerosol-cloud interactions on past and future changes in tropospheric composition, Atmos. Chem. Phys., 9, 4115-4129, doi:10.5194/acp-9-4115-2009, 2009.

Uppala, S. M., KÅllberg, P. W., Simmons, A. J., Andrae, U., Bechtold, V. D. C., Fiorino, M., Gibson, J. K., Haseler, J., Hernandez, A., Kelly, G. A., Li, X., Onogi, K., Saarinen, S., Sokka, N., Allan, R. P., Andersson, E., Arpe, K., Balmaseda, M. A., Beljaars, A. C. M., Berg, L. V. D., Bidlot, J., Bormann, N., Caires, S., Chevallier, F., Dethof, A., Dragosavac, M., Fisher, M., Fuentes, M., Hagemann, S., Hólm, E., Hoskins, B. J., Isaksen, L., Janssen, P. A. E. M., Jenne, R., Mcnally, A. P., Mahfouf, J.-F., Morcrette, J.-J., Rayner, N. A., Saunders, R. W., Simon, P., Sterl, A., Trenberth, K. E., Untch, A., Vasiljevic, D., Viterbo, P., and Woollen, J.: The ERA-40 re-analysis, Q. J. Roy. Meteorol. Soc., 131, 2961-3012, doi:10.1256/qj.04.176, 2005.

van Aardenne, J., Dentener, F., Olivier, J., Goldewijk, C., and Lelieveld, J.: A 11 resolution data set of historical anthropogenic trace gas emissions for the period 1890-1990, Global Biogeochem. Cy., 15, 909-928, 2001.

van Noije, T. P. C., Segers, A. J., and van Velthoven, P. F. J.: Time series of the stratosphere-troposphere exchange of ozone simulated with reanalyzed and operational forecast data, J. Geophys. Res., 111, D03301, doi:10.1029/2005JD006081, 2006.

Vautard, R., Szopa, S., Beekmann, M., Menut, L., Hauglustaine, D. A., Rouil, L., and Roemer, M.: Are decadal anthropogenic emission reductions in Europe consistent with surface ozone observations?, Geophys. Res. Lett., 33, L13810, doi:10.1029/2006GL026080, 2006.
Vignati, E., Wilson, J., and Stier, P.: M7: An efficient sizeresolved aerosol microphysics module for large-scale aerosol transport models, J. Geophys. Res.-Atmos., 109, D22202, doi:10.1029/2003JD004485, 2004.

Wang, K., Dickinson, R., and Liang, S.: Clear sky visibility has decreased over land globally from 1973 to 2007, Science, 323, 1468-1470, 2009.

Wild, M.: Global dimming and brightening: A review, J. Geophys. Res., 114, D00D16, doi:10.1029/2008JD011470, 2009.

Wilson, R. C., Fleming, Z. L., Monks, P. S., Clain, G., Henne, S., Konovalov, I. B., Szopa, S., and Menut, L.: Have primary emission reduction measures reduced ozone across Europe? An analysis of European rural background ozone trends 1996-2005, Atmos. Chem. Phys. Discuss., 11, 18433-18485, doi:10.5194/acpd-11-18433-2011, 2011.

Zhang, Q., Streets, D. G., Carmichael, G. R., He, K. B., Huo, H., Kannari, A., Klimont, Z., Park, I. S., Reddy, S., Fu, J. S., Chen, D., Duan, L., Lei, Y., Wang, L. T., and Yao, Z. L.: Asian emissions in 2006 for the NASA INTEX-B mission, Atmos. Chem. Phys., 9, 5131-5153, doi:10.5194/acp-9-5131-2009, 2009. 